\title{
EFEITO DO TRATAMENTO TÉRMICO E DA DEFECACÃO SIMPLES DO CALDO DE CANA SOBRE A CONCENTRAÇÃO DE N, P E A FERMENTAÇÃO ALCOÓLICA
}

ILA MARIA DE AGUIAR OLIVEIRA

Orientador: Prof. Dr. JORGE HORII

Dissertação apresentado à Escola Superior de Agricultura "Luiz de Queiroz", da Universidade de São Paulo, para obtenção de título de MESTRE EM AGRONOMIA. Área de Concentração: Tecnologia de Alimentos.

PIRACICABA

Estado de São Paulo - Brasil

Março - 1986 
Aos meus pais, irmãos e avō, com carinho, DEDICO. 


\section{Agranecimentos}

Ao Prof. Dr. Jorge Horii pela orientação competente, atenção e apoio prestados na realização deste trabalho.

A Universidade do Amazonas que possibilitou a nossa participação no Curso de Pós-Graduação em Tecnologia de Alimentos.

Ao Departamento de Tecnologia Rural - ESALQ-USP, pela colaboração na presente pesquisa.

À CAPES, pela bolsa concedida.

Ao Prof. Dr. Décio Barbin e Dr. Marinéia de Lara Haddad, pela orientação nas análises estatísticas.

À estagiária Eliane Lafrata, pela colaboração na condução do experimento.

À bibliotecária Lücia Vasconcellos de Arruda Botelho, pela orientação bibliográfica.

Aos amigos do Curso de Pós-Graduação pela convivência e incentivo. 


\section{Efeito do Tratamento Termico e da Defecaçáo Simples do Caldo de Cana sobre a Concentração de N,P e. a Fermentação Alcoólica}

ALITORA: ILA MARIA DE AGUIAR OLIVEIRA ORIENTADOR: PROF. DR. JORGE HORII

\section{RESUMO}

Caldos de cana-de-açūcar foram submetidos a aquecimento a $10.0^{\circ} \mathrm{C}$ por 5 e 60 minutos e à defecação simples, também pelos mesmos períodos, e analisados, após trata mento e centrifugação, quanto aos teores de nitrogênio total, amoniacal, protéico, não protéico, fosfato inorgânico e contagem microbiana. Esses caldos foram a seguir submetidos à fermentação alcoólica por cerca de 24 horas, mediante a inoculação de uma suspensão acidulada a pH 2,5, contendo $25 \mathrm{~g} / 100 \mathrm{ml}$ de fermento prensado Fleischmann. Com a análise do vinho resultante, calcularam-se as eficiências de fermentação e de conversão. A remoção de nitrogênio total do caldo tratado e centrifugado, em ambos os tratameritos, foram de 20,78 a $26,14 \%$. O nitrogênio amoniacal praticamente não é removido pelo aquecimento e o nivel de redução, na defecação simples,é muito pequeno a pH 6,0. Ocorreu acréscimo de nitrogênio na fração não protéica do caldo submetido somente 
a aquecimento, embora permanecesse estāvel nos caldos tratados por defecação simples. Houve redução de fosfato inorgânico da ordem de 3,0 a 30,0\%, respectivamente, para os tratamentos. o aquecimento reduziu drasticamente a população microbiana, em cerca de 99,9\%. As variaçöes na composição do caldo resultante dos tratamentos não influíram, todavia, nas eficiências fermentativa e de conversão, demonstrando que, aos níveis ensaiados, não ocorre prejuízo à qualidade do mosto que possa se refletir na eficiência do processo. 


\section{Effect of Sugar Cane Juice Thermal Treatment and Single Lime Defecation on the Alcoholic Fermentation and Nitrogen Phosphorus Contents}

ALITHOR: ILA MARIA DE AGUIAR OLIVEIRA ADUISER: PROF. DR. JORGE HORII

\section{SUMMARY}

Sugar cane juices were submitted to heating at $100^{\circ} \mathrm{C}$ and single lime defecation for 5 and 60 minutes. Samples of the treated juices were centrifuged and their total, ammoniacal, proteic and non-proteic nitrogen and inorganic phosphorus contents were determined as well as the total microbiological count. These treated juices submitted to alcoholic fermentation for 24 hours by the innoculation with Fleischmann pressed yeast suspension containing $25 \mathrm{~g} /$ $100 \mathrm{ml}$ (yeast/water) acidulated at pH 2.5. The fermentation and conversion efficiencies were calculated from the results of the wine analysis. The total nitrogen removal of the treated and centrifuged juices in both treatments varying from $20.78 \%$ to $26.24 \%$. Ammoniacal nitrogen is not removed by heating and the reduction level during single lime defecation is very low at pH 6.0. There has been an increase in the non-proteic nitrogen fraction of the juices submitted 
to single lime defecation. Inorganic phosphorus was also reduced in $3 \%$ and $30 \%$ in the juices treated by heating and single lime defecation, respectively. Heating has drastically reduced the microbiological population in 99.9\%. The variations in the treated juices composition did not influence in the fermentation and conversion efficiencies, showing that at the tested levels there is no harm to the wort quality that may reflect on the process efficiency. 


\section{N D I CE}

Păgina

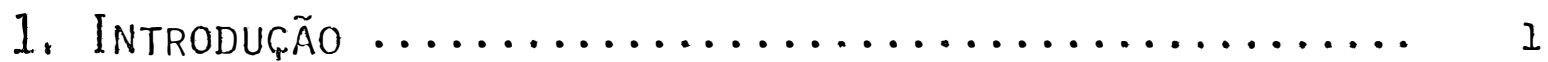

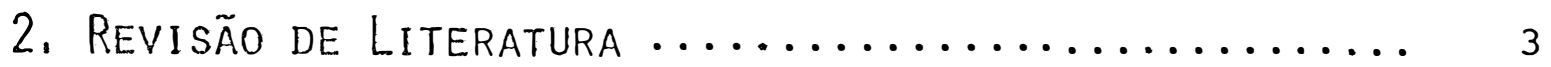

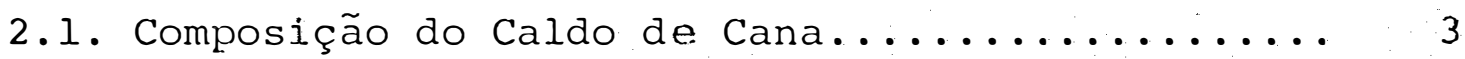

2.1.1. Nitrogênio .................... 9

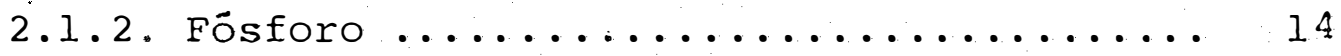

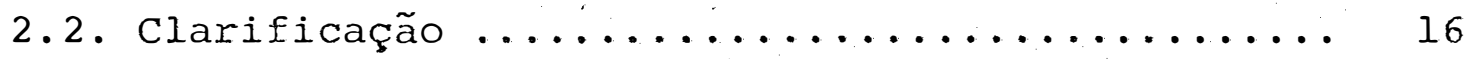

2.2.1. Proteínas e Aminoācidos ............ 20

2.2 .2 . Fosfatos ................... 37

2.3. Microorganismos ...................... 42

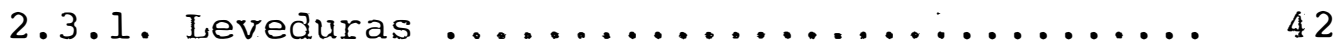

2.3.2. Microflora do Caldo Tratado Termicamente 52

3. Material e Métodos $\ldots \ldots \ldots \ldots \ldots \ldots \ldots \ldots \ldots \ldots \ldots . \ldots \ldots$

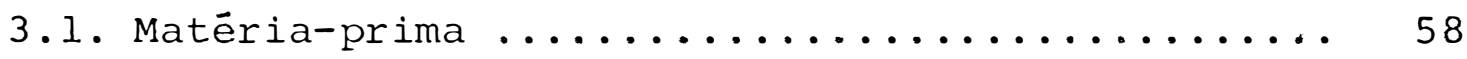

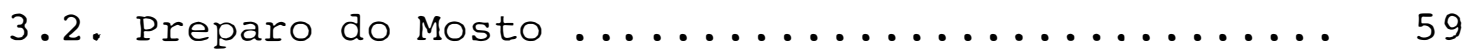

3.3. Preparo do Inóculo ...................... 59

3.4. Conduçã̃o do Experimento ................. 59

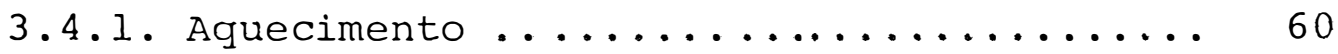

3.4.2. Defecação Simples ...................61

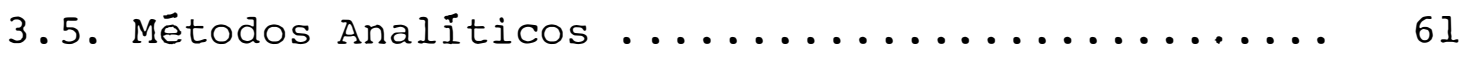

3.6. Fermentação Alcoólica ....................... 63

3.7. Delineamento Experimental e Anālise Estatística 64 
Pāgina

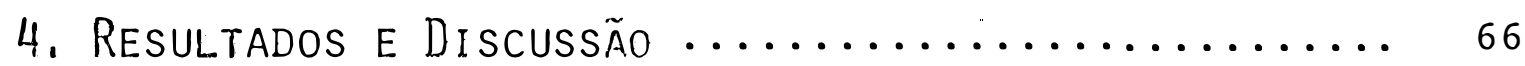

4.1 . Composição ....................... 66

4.2. Tratamento Térmico ...................... 71

4.2.1. Nitrogênio ..................... 72

4.2.2. Fósforo ........................ 81

4.2.3. Contagem de Microorganismos ......... 83

4.3. Defecação Simples .................. 86

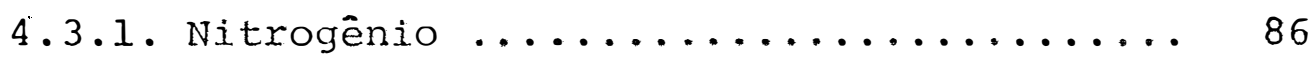

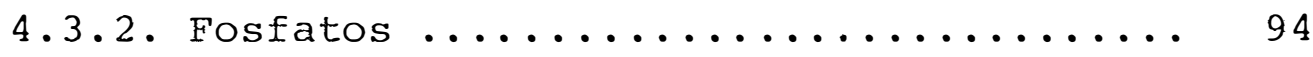

4.3.3. Contagem de Microorganismos ......... 98

4.4. Fermentação ........................ 100

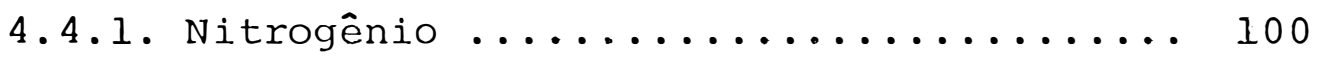

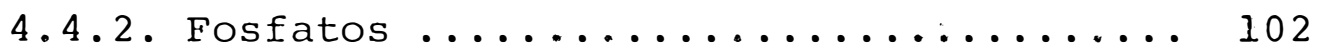

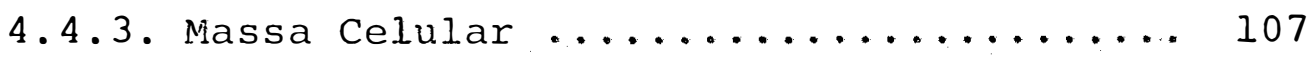

4.4.4. Eficiência de Fermentação e de Conver-

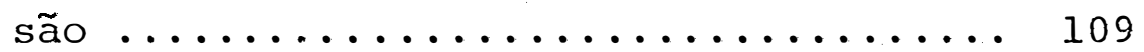

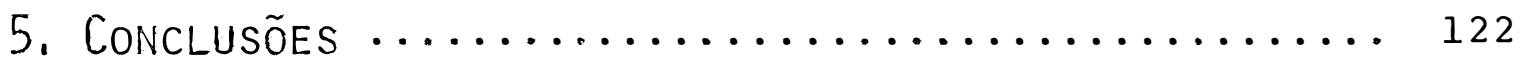

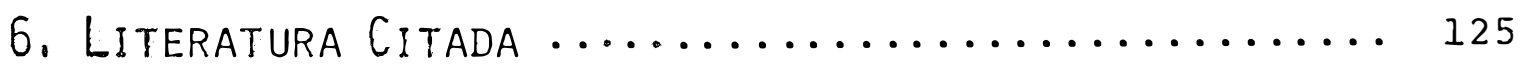

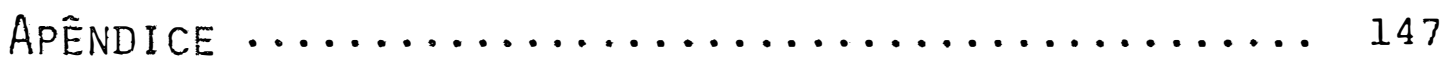




\section{Lista de Tabelas}

Pāgina

Tabela 1 - Teor de nitrogênio total, amoniacal, não protéico e protéico contido nos caldos

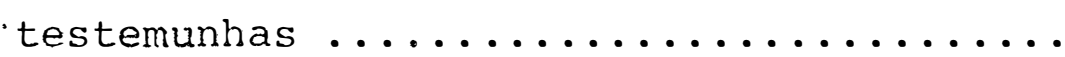

Tabela 2 - Composição dos caldos de cana em relação aos teores de nitrogênio, fosfato inorgâni

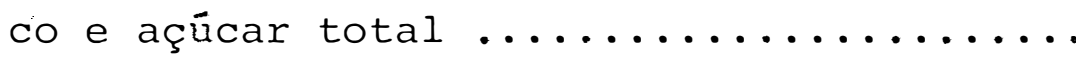

Tabela 3 - Teor de nitrogênio total, protéico, amonia cal e não protéico contidos no caldo em função do tratamento térmico ...........

Tabela 4 - Remoção de nitrogênio total durante o tratamento térmico do caldo ............ 75

Tabela 5 - Remoção de nitrogênio protéico durante o tratamento térmico do caldo .......... 78

Tabela 6 - Teor de fosfato inorgânico contido no caldo em função do tratamento térmico ........

Tabela 7 - População microbiana do caldo de cana....

Tabela 8 - Teor de nitrogênio total, protéico, amonia cal e não protéico contidos no caldo em função da clarificação por defecação simples.. 
Tabela 9 - Remoção de nitrogênio total do caldo, durante o processo de defecação simples.........

Tabela 10- Remoção de nitrogênio protéico do caldo, durante o processo ảe defecação simples......

Tabela 11- Teor de fosfato inorgânico contido no caldo, em função da clarificação por defecação sim

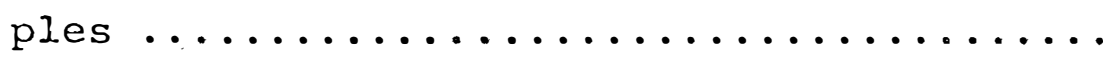

Tabela 12- Remoção de fosfato inorgânico do caldo, durante processo de defecação simples........

Tabela 13- População microbiana do caldo,após clarifi-

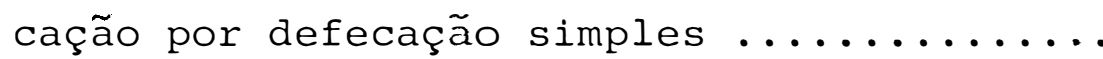

Tabela 14- Teor de nitrogênio total, amoniacal, não protéico e protéico contidos no caldo e vinho, em função do tratamento térmico ....

Tabela 15- Teor de nitrogênio total, amoniacal, não protéico e protéico contidos no caldo e vinho, em função da clarificação por defecação

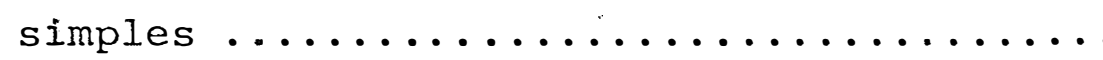

Tabela 16- Teor de fosfato inorgânico contido no vinho e consumido em função do tratamento térmico 
Tabela 17 - Teor de fosfato inorgânico contido no vinho e consumido em função do processo de defeca ção simples ..................... 106

Tabela $18^{\prime}$ - Influência do tratamento térmico na produ ção de massa celular ................. 108

Tabela 19 - Influência da defecação simples na produção

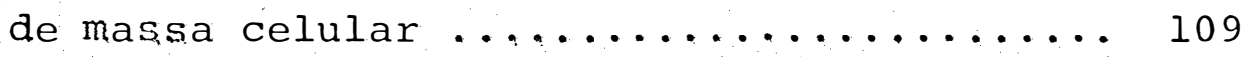

Tabelas 20 a 25. - Parâmetros das fermentações de caldos testemunha, tratamento tērmico e defecação 112 simples .......................... 17

Tabela 26 - Eficiências de fermentação e de conversão em caldos com tratamento térmico......... 118

Tabela 27 - Eficiências de fermentação e de conversão em caldos com defecação simples ......... 119 


\section{Lista dE fuAdros}

Pảgina

Quadro 1 - Efeito do tratamento térmico do caldo no

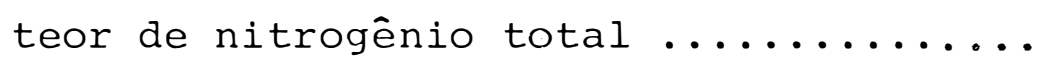

Quadro 2 - Efeito do tratamento térmico do caldo no

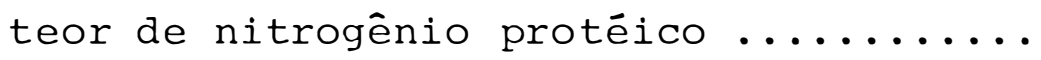

Quadro 3 - Efeito do tratamento térmico do caldo no teor de nitrogênio amoniacal .........

Quadro 4 - Efeito do tratamento térmico do caldo no teor de nitrogênio não protéico........

Quadro 5 - Teor de fosfato contido no caldo em função do tratamento térmico ............

Quadro 6 - Efeito do tratamento térmico do caldo na população microbiana ...........

Quadro 7 - Efeito da defecação simples do caldo no

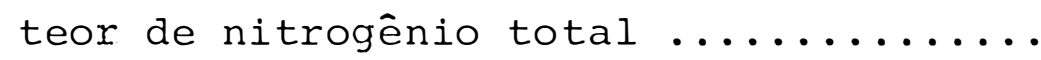

Quadro 8 - Efeito da defecação simples do caldo no teor de nitrogênio protéico ..........

Quadro 9 - Efeito da defecação simples do caldo no teor de nitrogênio não protéico ....... 
Quadro 10 - Efeito da défecação simples do caldo no teor de nitrogênio amoniacal ..........

Quadro 11 - Teor de fosfato contido no caldo em função da clarificação por defecação simples

Quadro 12 - Efeito da defecação simples do caldo na

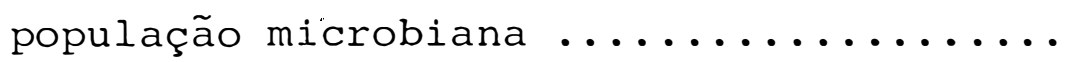

Quadro 13 - Eficiência de fermentação em caldos com

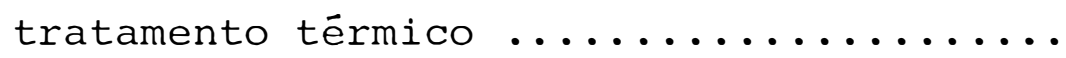

Quadro 14 - Eficiência de conversão em caldos com trạ

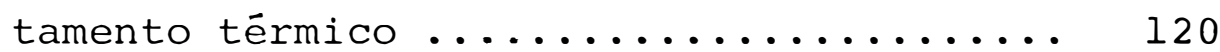

Quadro 15 - Eficiência de fermentação em caldos com

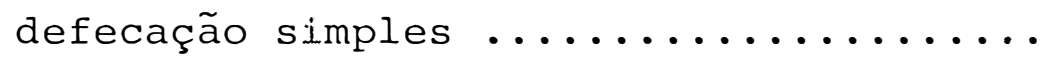

Quadro 16 - Eficiência de conversão em caldos com

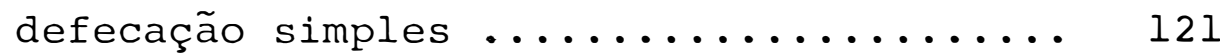

Quadro 17 - Efeito do tratamento térmico do caldo na população microbiana - Amostra I ....... 148

Quadro 18 - Efeito do tratamento térmico do caldo na população microbiana - Amostra $2 \ldots . . . .148$

Quadro 19 - Efeito do tratamento térmico do caldo na população microbiana - Amostra $3 \ldots . .$. 
Quadro 20 - Efeito do tratamento térmico do caldo na população microbiana - Amostra $4 \ldots \ldots . .$.

Quadro 21. - Efeito do tratamento térmico do caldo na população microbiana - Amostra $5 \ldots . . . .150$

Quadro 22 - Efeito do tratamento térmico do caldo na população microbiana - Amostra $6 \ldots \ldots . . . .150$

Quadro 23 - Efeito do tratamento térmico do caldo na população microbiana - Amostra $7 \ldots . . . .151$

Quadro 24 - Efeito da defecação do caldo na população microbiana - Amostra 1 ............. 151

Quadro 25 - Efeito da defecação do caldo na população microbiana - Amostra $2 \ldots \ldots \ldots \ldots \ldots$

Quadro 26 - Efeito da defecação do caldo na população microbiana - Amostra $3 \ldots \ldots \ldots \ldots \ldots$

Quadro 27 - Efeito da defecação do caldo na população microbiana - Amostra 4

Quadro 28 - Efeito da defecação do caldo na população microbiana - Amostra $5 \ldots \ldots \ldots \ldots$

Quadro 29 - Efeito da defecação do caldo na população microbiana - Amostra 6 
Pāgina

Quadro 30 - Efeito da defecação do caldo na população microbiana - Amostra $7 \ldots \ldots \ldots \ldots$

Quadro 31. - Efeito da defecação do caldo na população microbiana - Amostra $8 \ldots \ldots \ldots \ldots \ldots$

Quadro 32 - Efeito da defecação do caldo na população microbiana - Amostra $9 \ldots \ldots \ldots \ldots$

Quadro 33 - Efeito da defecação do caldo na população microbiana - Amostra $10 \ldots \ldots \ldots \ldots \ldots$ 


\section{INTRODUÇÃO}

Desde a criação do PROALCOOL, a instalação de destilarias autônomas e ampliações de usinas para produção de álcool têm sido realizadassem que sigam critérios técnicos, principalmente no que tange ao setor de tratamento do caldo de cana. Mais que as Instituições püblicas ou privadas, as próprias indústrias vêm desenvolvendo pesquisas e adotando critérios segundo a conveniência particular de cada empresa. são conhecidos mais de uma dezena de processos de tratamento e inúmeros equipamentos modificadores desses processos, atual mente em uso. Todavia, a maior parte deles considera que o objetivo maior da clarificação é a eliminação da quantidade. máxima de impurezas do caldo, procurando não afetar a composição química do mosto resultante.

Os agentes básicos mais utilizados na clarificação são o calor e a cal, e a aplicação em processo tem sido feita por analogia à clarificação do caldo para fabricação de 
açúcar, somente em caráter mais brando em relação a cal, pois os efeitos destas operações na indústria do açúcar; são bem estudados. Por inexistirem trabalhos, nesta área para fabricação de álcool, no tocante a alterações de composição química e, principalmente, remoção ou destruição de substâncias consideradas nutrientes para a fermentação alcoólica, este assunto vem sendo considerado dos mais polêmicos entre os técnicos do setor.

Quanto ao sucesso dos tratamentos térmicos e da defecação simples a pH em torno de 6,0,em relação à formạ ção de espumas, consumo de antiespumantes, redução de microor ganismos contaminantes, corrosão e abrasão em equipamentos, parece já haver quase um consenso de sua validade.

O objetivo do presente trabalho foi mostrar a influência do tratamento térmico e da defecação simples sobre as substâncias nitrogenadas e fosfatos, considerados prin cipais nutrientes do caldo, bem como a qualidade microbiológ ca e todos estes fatores em relação à eficiência de fermentação e conversão. 


\section{ReVisÃo de Literatura}

\subsection{Composição do Caldo de Cana}

O caldo de cana apresenta composição extremamente variável em função da variedade, idade, estágio de maturação, sanidade da cultura, condições climáticas, nature za do solo, adubação, etc., o que torna imprescindivel à determinação de sua composição química para uma boa condução do processo fermentativo.

Segundo PAYNE (1969), o caldo cru extraído das moendas é um dispersóide constituído de materiais em todos os graus de dispersão, desde partículas grosseiras até íons.

O material grosseiro disperso no caldo consiste principalmente de terra, partículas de bagaço e cera, e segundo a classificação de Von Weimarn e Ostwald, citados por PAYNE (1969), apresentam diâmetros superiores a 0,0001 nm. 
A fração intermediāria entre as dispersões grosseiras e os dispersóides moleculares e iônicos é constituída pelas proteínas, gomas, ceras, lipídios, pectina, taninos e materiais corantes que permanecem em solução coloi dal. Também uma quantidade variāvel de matéria coloidal pode ser introduzida no caldo devido ao crescimento e ação dos microorganismos. A quantidade de matéria coloidal situa-se entre os limites de 0,05 e 0,30\% do caldo, cujas particulas têm um diâmetro de 0,0001 a $0,000001 \mathrm{~mm}$.

Ainda de acordo com PAYNe (1969) as disper sões iônicas e moleculares incluem o açūcar e os constituintes das cinzas apresentando partículas de 0,000 $001 \mathrm{~mm}$ e menores.

Segundo BENNETT (1957b), o caldo de cana é um sistema coloidal natural contendo muito material em suspensão e rico em proteínas e polissacarídeos solúveis; havendo, contudo, poucas referências concernentes à relação física en tre estes vários constituintes.

As partículas suspensas no caldo de cana podem ser vistas ao microscópio e têm diâmetros acima de $6 \mu$, estão presentes em densidades entre $2,5 \times 10^{8} \mathrm{e} 1,2 \times 10^{9}$ partículas/ml. Um estudo do sedimento e do líquido sobrena dante obtido pela centrifugação de amostras do càldo a lo00g tem mostrado que cerca de $85 \%$ das partículas presentes apresentam diâmetros em torno de $2 \mu$, enquinto somente 5\% tèm 
diâmetros de $4 \mu$ ou maiores.

Quanto à natureza das partículas suspensas, BENNETT (1957b), classificou-as em dois tipos principais: (1) partículas cerosas, compostos principalmente de uma mistura de ésteres de álcool ceril com longas cadeias de ácidos graxos, mas contendo também apreciáveis quantidades de ácidos livres e alcoóis, alguns esteróis, fosfolipídeos, e resinas não identificadas, tendo a mistura um. peso específico $(1,2)$ maior que o meio de dispersão. (2) cloroplastos e polissacarídeos - ou gomas - contendo plastídeos lisados a par tir da ruptura das células de cana. Partículas sedimentadas com $4-6 \mu$ de diâmetro têm um alto conteúdo mineral (principal mente silicato) e devem formar um terceiro tipo de partícu las presentes no caldo de cana, embora em pequena quantidade Foi evidenciado que 50 a $75 \%$ de todas as partículas do caldo cru são do tipo cerosa.

A quantidade total da fase dispersa é pequena $(0,25 \% \mathrm{p} / \mathrm{p})$ e coloca 0 caldo de cana entre as "suspensōes diluídas" ou soluções em que não é necessária a adição de es tabilizador para prevenir a floculação espontânea. O sistema de partículas heterogêneas no caldo de cana é, contudo, ele troforeticamente homogêneo.

Além da diferença entre caldos de diferentes variedades de cana, a mesma cana pode produzir caldo de composição variável, segundo o grau d moagem (GEERLIGS, 1924 
e SPENCER e MEADE, 1945). Este fenômeno é façilmente explicạ vel pelos diferentes graus de dureza dos tecidos e pelos diferentes tipos de albúmen presentes na cana.

Segundo SPENCER e MEADE (1945) em moagens mais extensivas é maior a extração de não açūcares em relação aos açūcares. Contudo, estas variações na composição são mais quantitativas que qualitativas, mas em proporções variā veis.

Os sólidos do caldo podem ser divididos em açūcares, não açūcares inorgânicos (cinzas), e não açūcares orgânicos, mas segundo Fort e Mckaig, citados por SPENCER e MEADE (1945), não há uma divisão precisa entre os dois últimos. A quantidade de cinzas não é uma medida do teor de sal já que alguns sais estão presentes em combinação com não açū cares orgânicos.

DAVIES (1936) apresenta os seguintes limites de composição do caldo cru:

Constituintes.

Ågua

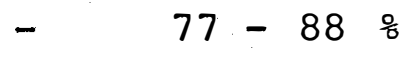

Sacarose

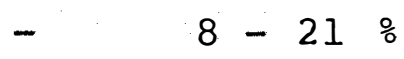

Açūcares Redutores

$-\quad 0,3-3,0 \%$

Outros compostos orgânicos -

$0,5-1,0 \%$

Compostos inorgânicos

$0,2-0,6 \%$

Browne, citado por SPENCER e MEADE (1945) re- 
lata a composição, dos colmos da cana de Louisiânia na época de colheita, novembro-dezembro.

Composição da Cana-de-Açúcar em Iouisiânia, USA

Agua....... 74,50\%

$74,50 \%$

Cinzas..... 0,50

Oxido de silico, $\mathrm{SiO}_{2} \quad 0,25$

Oxido de potássio, $\mathrm{K}_{2} \mathrm{O} \quad 0,12$

Oxido de sódio, $\mathrm{Na}_{2} \mathrm{O} \quad 0,01$

Óxido de cálcio, CaO 0,02

Óxido de magnésio, MgO 0,02

Oxido férrico, $\mathrm{Fe}_{2} \mathrm{O}_{3}$

Anidrido fosfórico, ${ }^{\mathrm{P}}{ }_{2} \mathrm{O}_{5} \quad 0,07$

Anidrido sulfúrico, $\mathrm{SO}_{3} \quad 0,02$

Cloro

Fibra...... 10,0

$\begin{array}{ll}\text { Celulose } & 5,50\end{array}$

$\begin{array}{ll}\text { Pentosanas xilana } & 2,00\end{array}$

$\begin{array}{ll}\text { (gomas) Arabana } & 0,50\end{array}$

Lignina $\quad 2,00$

Açūcar ......14,00

$\begin{array}{ll}\text { Sacarose } & 12,50\end{array}$

$\begin{array}{ll}\text { Dextrose } & 0,90\end{array}$

Luvulose $\quad 0,60$ 
Compostos

Nitrogenados..... 0,40

$\begin{array}{lc}\text { Albuminōides } & 0,12 \\ \text { Amidas (asparagina) } & 0,07 \\ \text { Aminoācidos (aspārtico) } & 0,20 \\ \text { Ácido nítrico } & 0,01 \\ \text { Amônia } & - \\ \text { Corpos xânticos } & -\end{array}$

Lipídeos e ceras.. 0,20

0,20

Pectina (gomas) ... 0,20

0,20

Ácidos livres.... 0,08

0,08

Ácidos combinados. 0,12

0,12

Segundo GUPTA e PRASAD (1967), a qualidade da cana depende de muitos fatores tais como: variedade, tipo de solos, clima, adubação, irrigação, etc., tendo a variedade da cana um importante papel na absorção de minerais do so 10. A absorção de vārios nutrientes é em grande parte uma característica específica da variedade da cana que é influen ciada pelas alterações climáticas e edafobiológicas.

Anālises feitas por SHARMA e GUPTA (1970), dẹ monstraram que o teor de cinzas foi maior no āpice que nas porções mediana e basal do colmo, apresentando uma contínua tendência a elevar-se durante o período de maturidade máxima, e mantendo-se a um nível normal para, depois de atingir um mâa ximo; tender a um declínio.

Os referidos autores constataram que o teor 
de açúcares redutores têm sido maior nos estágios iniciais de crescimento da cana. A distribuição máxima dos açūcares redutores do topo, base e a cana composta têm se tornado mais ou menos igual; após o período de maturação máxima os açúcares têm demonstrado uma tendência a aumentar, embora não na mesma extensão da cana não maturada. A tendência do teor de açúcares redutores decrescer coincide com a obtenção da maturação máxima.

De acordo com SPENCER e MEADE (1945), os não açúcares orgânicos do caldo são constituídos por lipídeos e ceras, substâncias nitrogenadas, gomas, ácidos orgânicos, he miceluloses, pentosanas, etc. A percentagem de não açúcares total pode ser obtida pela subtração da soma de sacarose, açúcares redutores, e cinzas dos sólidos verdadeiros. Os não açúcares orgânicos totais do caldo de cana de Louisiana variaram de 5,69 a 6,42 por cento de sólidos no caldo. A média baseada no próprio caldo foi de aproximadamente $1 \%$

\subsubsection{Nitrogênio}

Referindo-se à cultura de cana-de-açūcar, o nitrogênio afeta a composição, produção e migração de açúcares, havendo evidência que altos níveis de nitrogênio promovem uma diminuição na concentração de sacarose e aumento no teor de açúcares redutores (DAS, 1936; BORDEN, 1948; HARTT, 1970). 
Na planta, o nitrogênio pode ser dividido em três grandes frações: $\mathrm{N}$-inorgânico $\left(\mathrm{N}-\mathrm{NO}_{3}, \mathrm{~N}-\mathrm{NH}_{4}\right), \mathrm{N}-\mathrm{NH}_{2}$ solúvel e $N$ protéico. Todas três frações são influenciadas pela nutrição da planta. Destas, $\mathrm{O} N-\mathrm{NH}_{2}$ solúvel (aminoácidos, ami nas e amidas) é a fração mais variável em função de distürbios nutricionais, sendo que o conteúdo de proteínas varia so mente em condições extremas (GOSWAMI e WILLCOX, 1969; BEEVERS E HAGEMAN, 1969).

Em análises feitas por FORT e MCKAIG JR.(1939)em caldo de cana da Louisiânia referente ao teor de nitrogênio, verificou-se que a mesma apresentava as seguintes variações:

\begin{tabular}{lll}
\hline & Mínimo & Máximo \\
\hline Nitrogênio total & $0,047 \%$ & $0,40 \%$ \\
Nitrogênio protéico & $0,033 \%$ & $0,13 \%$ \\
Nitrogênio não protéico & $0,021 \%$ & $0,28 \%$ \\
\hline
\end{tabular}

$$
\text { Browne (1910), citado por SPENCER e MEADE }
$$

(1945) determinou em época de safra a seguinte composição do colmo da cana da Louisiânia com relação ao material nitrogenado:

\begin{tabular}{lc}
\hline Compostos Nitrogenados & $\circ$ Colmo da cana \\
\hline Albuminas e compostos similares & 0,12 \\
Aminoácidos & 0,20 \\
Aminoácidos-amidas & 0,07 \\
Amoníaco & - \\
Nitrato & 0,01 \\
\hline
\end{tabular}


Já Hardin, citado por FARNezL (1924), encon trou a seguinte distribuição correspondente ao nitrogênio:

\begin{tabular}{lcc}
\hline Compostos Nitrogenados & \% do caldo & \% do total \\
\hline Nitrogênio como albumina & 0,0039 & 9,75 \\
Nitrogênio em corpos de nucleína & 0,0025 & 6,25 \\
Nitrogênio como albumosas (proteoses) & 0,0021 & 5,25 \\
Nitrogênio em aminoácidos & 0,0122 & 30,50 \\
Nitrogênio en aminoácidos amidas & 0,0098 & 24,50 \\
Nitrogênio em amônia & 0,0024 & 6,00 \\
Nitrogênio em nitratos & 0,0071 & 17,75 \\
\hline Total & 0,0400 & 100,00 \\
\hline
\end{tabular}

Browne e Blowin, citados por WIGGINS (1969), es timaram que na cana da Louisiânia, o nitrogênio estava presen te atē a concentração de 0,05\%. GEERLIGS (1924) estipulou 0,036: como média do nitrogênio no caldo de cana.

WIGGINS (1969), ao analisar uma cana madura da variedade $B 37.161$ verificou que os compostos nitrogenados se apresentavam em diferentes concentrações nas diversas partes da planta: as folhas verdes continham $0,8 \%$ de nitrogênio, na matéria seca, ou $0,32 \%$ em material fresco; 0 ,4\% nas raízes dessecadas e os colmos apresentavam 0,084\% na matéria seca ou $0,022 \%$ no material recentemente cortado. o caldo de cana extraido em moendas continha $0,018 \mathrm{~g}$ de nitrogênio/100 $\mathrm{ml}$. 
Com relação à distribuição do material nitroge nado no colmo da cana, GEERLIGS (1924) relata que as substâncias albuminóides estão concentradas nos nós, enquanto os compostos mais simples, aminoácidos-amidas, estão presentes em um grau mais pronunciado nos entrenós.

A cana-de-açúcar varia em sua composição em dị ferentes países, bem como em diferentes localidades de um mesmo país, e em diferentes anos na mesma localidade (SPENCER e MEADE, 1945).

No Havaí, LEE (1926) encontrou que o teor mé-dio de nitrogênio de muitas amostras de raízes de cana era de $0,7 \%$. GEERLIGS (1924) assinala que o teor de nitrogênio do caldo pode variar entre 0,018 e 0,062\%. SPENCER e MEADE (1945) dão a cifra de 0,06\% de nitrogênio para a cana da Louisiânia.

BINKLEY (1959), ao reconstituir liofilizado de caldo misto bruto apresentou a seguinte compósição em relação ao nitrogênio: nitrogênio solúvel, 0,304\%; nitrogênio coagulā vel, $0,096 \%$

RAMCHANDER e RAO (1957), observaram que a canade-açúcar que cresce em solo ácido e seco fornece caldo que é caracterizado por baixo pH e grande teor de nitrogênio e não açúcares. 
KOWNABANY et alii (1953), evidenciaram que pelo menos 75\% da substância nitrogenada comporta-se como aminoácí do; sendo a asparagina o aminoácido predorninante, seguido pela alanina, ácido glutâmico e serina.

Segundo HONIG (1934), a presença de compostos nitrogenados no caldo é a metade daqueles encontrados na cana. A percentagem é muito maior no caldo da segunda e terceira moendas, mostrando que o grau de extração è de grande influên cia (GEERLIGS, 1924).

WILSON (1956), afirma que a composição de amino ácidos no caldo de cana é dependente da estação e do método de extração. Caldos obtidos por maceração contêm maiores percentagens que caldos prensados.

Segundo WIGGINS e WILLIAMS (1951), embora qualitativamente o quadro geral de aminoácidos tenha sido sempre o mesmo, a quantidade total de aminoácidos no ápice da cana é sempre maior, cai para um mínimo no centro do colmo e aumenta novamente na base. Os teores têm sido majores nos estágios iniciais de crescimento e variam grandemente em dife rentes variedades.

Os mesmos autores (1955), evidenciaram a presença de 9 aminoácidos livres em 12 variedades de cana da India. 38\% do total de aminoácidos presentes no caldo de colmos de ápice verde foi de asparagina, totalizando $128,9 \mathrm{mg} \%$ 
Análises feitas por TAO-TZE at alii (1983), demonstraram que a concentração total de aminoácidos presentes no caldo dos colmos foi de $272,143 \mathrm{mg} / 100$ g, sendo encontrados 19 aminoácidos protéicos, 3 aminoácidos relacionados a compostos fosfoserina, fosfoetanolamina e etanolamina e 7 aminoácidos não protéicos.

O nitrogênio protéico total de um dado caldo deve ser considerado em três termos: (1) nitrogênio protéico intrínseco (proteínas que fazem parte de cloroplastos e plastídeos e não disponíveis para adsorção. (2) nitrogênio protéi co adsorvido (3) nitrogênio protéico dissolvido.

Segundo ROBERTS e MARTIN (1961), o teor de ami noácidos apresenta variaçäo ano a ano, ao passo que a composi ção e o teor de proteínas apresentam-se constantes.

FARNELL (1924), estimou que a proteina constituía $0,73 \%$ dos sólidos solúveis do caldo cru, porém, somente 29,4\% deste valor era matéria não dializável e, portanto, de verdadeira natureza protéica.

\subsubsection{Fosboro}

O fósforo presente no caldo de cana se apresen ta nas formas inorgânica (fosfatos solúveis, ions fosfatos li vres) e orgânica (fosfolipídeos, hexosefosfatos, fosfoproteínas), sendo a forma inorgânica fundamental no processo de 
clarificação.

Segundo SERRA et alii (1974), os teores médios de fósforo inorgânico, na região canaveira de Piracicaba, variam de 70 a $130 \mathrm{mg}$ de $\mathrm{P}_{2} \mathrm{O}_{5}$ por litro do caldo, no início do ciclo de maturação da cana, atingindo teores de 140 a 230 mg de $\mathrm{P}_{2} \mathrm{O}_{5}$ por litro de caldo, no fim do mesmo. O fósforo orgâni co varia aproximadamente entre 10 a $35 \mathrm{mg}$ de $\mathrm{P}_{2} \mathrm{O}_{5}$ por litro de caldo eseu teor geralmente representa 5 a 15\% do fósforo total no caldo de cana.

CESAR et alii (1974), estudando o teor de fósfo ro de algumas variedades de cana-de-açúcar (segundo corte), encontraram variações de 38 a $53 \mathrm{mg}$ de fósforo por litro de caldo $\circ$ que corresponde a 87 a $121 \mathrm{mg}$ de $\mathrm{P}_{2} \mathrm{O}_{5}$ por litro.

GLORIA e RODELLA (1972), encontraram teores medios de $18,36 \mathrm{mg} \mathrm{P}_{2} \mathrm{O}_{5} / 100 \mathrm{ml}$ nas amostras de caldo-de-cana analisadas.

O teor de fosfato é mais alto na ponta da cana que na base e na região mediana da cana. A distribuição de fosfato em várias porções indica que com o avanço da idạ de, o teor de fosfatos mostra uma tendência a aumentar a um máximo, seguido por um declínio após o período de maturação. o teor de fosfato, durante a máxima maturação, tem variado de 0,0269\% a 0,0312\% (SHARMA e GUPTA, 1970).

Em ensaios realizados em Java, por HONIG (1960), 
foi verificado que o teor de fosfato é maicr na parte basal da cana. As diferenças são de tal magnitude que quando $\circ \mathrm{P}_{2} \mathrm{O}_{5}$ na parte basal é 100, a parte mediana é aproximadamente 90 e o ápice 80.

SHARMA e GUPTA (1970), sugerem que o ápice da cana por possuir maiores percentagens de não açúcares orgânicos, deverá ter maior concentração de fosfato de natureza orgânica.

HONIG (1960), demonstrou que o nível de fosfato orgânico na cana e no caldo extraído de diferentes "campos" e variedades de cana, é mais uniforme que o fosfato inorgânico. o nível de fosfato orgânico é primeiramente uma função do grau de maturação da cana. O autor relata que o teor de fosfá to orgânico, no ápice da cana, representa 15 a $25 \%$ do fosfato total.

\subsection{Clarificação}

A clarificação do caldo de cana tem sido uma técnica restrita às usinas de açücar, e a literatura referente à purificação do caldo é voltada para essa prática nas usị nas, com poucas alusões ạo seu uso nas destilarias de ãlcool, visto ser quase que exclusivamente uma prática brasileira.

O caldo de cana bruto por apresentar alguma di ficuldade na sondução de sua fermentação, tem sido submetido 
a diferentes sistenas de tratamento, dentre os quais a clarificação, consistindo das seguintes etapas: eliminação de impu rezas grosseiras, aquecimento, caleagem, decantação, filtração e resfriamento do caldo, visando com isso, a remoção da máxima quantidade de impurezas do caldo nos estágios iniciais do processo.

o caldo de cana por ser uma suspensão coloidal irreversível poli-dispersa, isto é, uma solução em que as par tículas suspensas apresentam não somente diferentes tamanhos, mas são, também, heterogêneas quanto à composição química; a carga negativa destas partículas estabiliza o sistema coloi dal e previne a rápida sedimentação da fase dispersa (HIDI, 1969).

O fenômeno que ocorre na superfície das partículas durante o processo de clarificação é determinado, em grande parte, pela natureza da superfície da partícula.

Segundo DOOR e LASSETER (1946), os processos que levam à separação de fase numa suspensão, envolvem 3 etapas relativamente distintas: (1) desestabilização (2) agregação de partículas (3) sedimentação; cada uma dessas etapas pode ser grandemente influenciada pelas alterações na carga eletros tática destas partículas. Muita atenção tem sido dada com relação ao comportamento na sedimentação e o potencial zeta em soluções liofóbicas verdadeiras. Quando o potencial zeta é nụ mericamente pequeno, a solução é instável e as partículas flọ 
culam e o volume do sedimentado é maior, ocorrrendo o inverso quando o potencial zeta é grande (OVERBEEK, 1952).

BENNETT (1959), tem demonstrado em seus estudos com caldo de cana, que a estabilidade da suspensão é extrema mente sensível as alterações no potencial zeta, quando o valor numérico deste é menor que $10 \mathrm{mV}$, mas foi observado que esta sensibilidade não tem sido devidamente explorada no processo de clarificação comercial. Neste caso, a floculação é causada pela precipitação de fosfato de cálcio e os flocos supõem-se que consistam de um aglomerado de partículas ligadas a uma matriz de precipitado inorgânico. Este processo não é acompanhado por nenhuma alteração especial no potencial zeta.

No processo de clarificação comercial, as alterações que levam a desestabilização e consequente agregação de partículas, são geralmente ocasionadas pelo aquecimento do caldo após adição de leite de cal.

KING (1931), sobre este assunto, afirma que as alterações fundamentais ocorrentes durante a clarificação do caldo são as seguintes:

- modificação na concentração do íon hidrogênio, pela adição do leite de cal ao caldo;

- floculação de algum colóide, pela alteração na concentração hidrogeniônica;

- floculação de colóides pelo calor;

- formação de compostos solúveis e insolúveis 
de cálcio e seus respectivos complexos.

Se amostras de caldo bruto forem ajustadas a diferentes valores de pH entre 1 a 9, a floculação ocorre próximo ao $\mathrm{pH} 3,5$ e acima do $\mathrm{pH}$ 6,0, não havendo diferença na aparência dos flocos quando esses são examinados microscopicamente. Contudo, estas precipitações ocorrem por razões inteiramente diferentes: a precipitação a baixo pH é devido ao ponto isoelétrico das partículas em torno do $\mathrm{pH} 3,3$. Entre o pH 5,5 e 6,0,está associado com a precipitação do fosfato de cálcio e adsorção das proteínas presentes (BENNETT, 1957).

Muitas observações indicam que o grau de clarị ficação é consideravelmente influenciado pela completa neutra lização de cargas.

Em trabalho realizado por HIDI (1969), foi demonstrado que as partículas presentes nos caldos clarificados turvos apresentavam cargas negativas, evidenciando-se, nesse caso, que a quantidade de fosfato de cálcio carregado positivamente através da caleagem não era bastante para a neutralização de todas as cargas nos colóides do caldo original. A adição de sal fosfato ácido solūvel extra, reduziu significati vamente a turbidez do caldo clarificado através da completa neutralização de cargas dos colóides.

Aplicando-se o princípio da neutralização de cargas do colóide, foi também possível melhorar a clarificação dos caldos, simplesmente pelo aumento da concentração do ion 
cálcio. O papel da adição de İon cálcio extra não é tanto pelo aumento da quantidade de fosfato de cálcio precipitado, mas o aumento da carga positiva no fosfato de cálcio formado, tornando-o mais eficiente na neutralização de cargas negativas.

Foi demonstrado por BENNETT (1957a), BENNETT e RAGNAUTH (1960), que as concentrações de cálcio envolvidas na caleagem são bem abaixo da concentração requerida para atingir o ponto isoelétrico dos colóides naturais do caldo, na faixa de pH neutro.

\subsubsection{Proteinas e Aminoācidos}

Em média, a cana-de-açúcar contēm 0,02 - 0,06\% de nitrogênio, dos quais $60 \%$ estão presentes como amônia e. compostos amínicos. Os não açūcares contendo nitrogênio, presentes no caldo de cana são amidạ-aminoácidos, proteí nas e aminoácidos. Alguns dos aminoácidos são removidos durante o processo de clarificação, enquanto outros permanecem e têm a tendência de reagir com açúcar invertido e produzir escurecimento (SHARMA e JOHARY, 1984).

Num ensaio feito por PEREZ e GUTIERREZ (1977), com caldo de cana submetido a diferentes valores de $\mathrm{pH}$, veri ficou-se que existem duas zonas máximas de eliminação de proteínas: uma compreendida entre os valores de pH 2 e 4, con um aparente máximo em 3, e, outra, entre 8 e ll (com um máximo aparente em 9), já que a partir de 11 começa a diminuir sensivel 
mente a coagulação. Estes resultados possibilitam a existên cia de "2 pontos isoelétricos" para as proteínas, um na zona ácida de pH, e,outro, na zona alcalina.

Para confirmar esta possibilidade fizeram - se estudos com solução de ovoalbumina, observando-se uma maior eliminação de proteínas entre valor de $\mathrm{pH} 4$ e 5, sendo que a partir do pH 5 a concentração da solução sobrenadante tem uma tendência geral ao aumento, o que se deve a uma maior estabilidade das mesmas.

Ao se adicionar íons à solução de ovoalbumina nas concentrações correspondentes as existentes no caldo de cana, e,submetendo-se a variações de pH, observou-se que uma maior eliminação de proteínas ocorreu a valores de $\mathrm{pH} 6$ e 8, com um máximo em pH 8 . Os teores de proteína na solução sobre nadante em presença de íons são menores aos observados nos $\mathrm{pH}$ correspondentes em ausência de íons, principalmente, a $\mathrm{pH}$ 3, 6, 7 e 8. Esta maior eliminação se deve à ação de diferentes ions presentes e ao comportamento dos mesmos com relação ao pH. Conclui-se, portanto, que em solução de proteína pura, existe um máximo de coagulação na zona ácida, que se deve ao verđadeiro ponto isoelétrico da mesma, já que em solução de proteínas em presença de íons, existe um máximo de eliminação na zona alcalina, o que se deve à formação de um complexo quí mico de adsorção com os sais precipitados, principalmente os de cálcio. 
Sequndo REVA et alii (1983), vārios fatores $\mathrm{COH}^{-}, \mathrm{Ca}^{2+}$, adsorção em sais de cálcio, aquecimento de 20 e $85^{\circ} \mathrm{C}$ ) contribuem para remoção da proteîna durante a clari. ficação por defecação. Ao submeter caldo de beterraba a diversas condições de defecação tais como: a pH 6 - 12 a temperatura de $20-80^{\circ} \mathrm{C}$, tratamentos com CaO, $\mathrm{CaCl}_{2}, \mathrm{NaOH}$ por 10 minutos a uma hora, constatou-se que a remoção de 70-90\% das proteínas foi atingida a um pH ótimo de 11,4 - 11,5 e

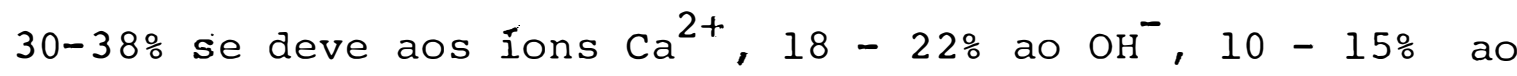
aumento de temperatura e 10-17\% a adsorção no precipitado de sais de cálcio. Excessiva caleagem causou precipitação, diminuindo a remoção em aproximadamente $8 \%$.

Num ensaio realizado por REVA et alii (1979), em que o caldo foi tratado com NaOH a pH 6-12,5 com e sem prévia adição de $\mathrm{CaCl}_{2}$ (correspondente a concentração de $\mathrm{Ca}^{2+}$ na pré-defecação), observou-se que na ausência de $\mathrm{Ca}^{2+}$, a remoção da proteína era de 17 - 20\% a pH 11,4 e 26\% a pH 12,5 . Na presença de $\mathrm{Ca}^{2+}$, essa rèmoção atingiu 48\% sendo mā xima a pH 11,4, e, com concentração equivalente a $0,2-0,3 \%$ de CaO. Nesse teste, a temperatura foi mantida a $20^{\circ} \mathrm{C}$ para evitar alguma desnaturação térmica e removeram-se. Ions oxalato, tartarato, citrato, fosfato para evitar adsorção pelos sais de cálcio.

STUDNICKY (1978), trabalhando com amostras de caldo de cana ajustadas a 17 valores de $\mathrm{pH}$ na faixa de 1,5510,85 usando $\mathrm{HCl}$ e $\mathrm{NaOH}$, e mantendo-se a $85^{\circ} \mathrm{C}$ por 30 minutos verificou a partir de anälises feitas no lodo, que 60\% do ni- 
trogênio total foi removido a pH 2,5 e $37 \%$ do nitrogênio foi removido entre $\mathrm{pH} 7$ e 8 .

VEGA (1957), encontrou que variando o pH de 1 a 7 e a temperatura de 20 a $80^{\circ} \mathrm{C}$ havia um intervalo de $\mathrm{pH}$ entre 3,2 e 3,4 para o qual a eliminação de proteínas era máximo. Variando a temperatura, a diferença na eliminação de impurezas era pequena; se bem que a $60^{\circ} \mathrm{C}$ se eliminava a maior quantidade de proteinas para todo o intervalo de $\mathrm{pH}$.

Segundo FARNELI (1924), num sistema contendo duas ou mais substâncias anfōteras, a máxima preçipitação está situada entre os $\mathrm{pH}$ dos pontos isoelétricos dós componentes individuais. De acordo com essa teoria o ponto isoelétrico do caldo de cana deve estar situado entre pH 3 e 6,1, visto que algumas das substâncias anfóteras que constituem o sistema säo as seguintes:

Albumina desnaturada $\mathrm{pH}$

Ācido aspártico 5,5

Asparagina 3,0

Glicina 5,5 6,1

SPENCER e MEADE (1945), constataram que a maior eliminação de compostos nitrogenados tem ocorrido a pH 6,5, utilizando-se o método de caleagem fṛacionada com duplo aquecị mento.

KING (193I), ao proceder caleagern a pH mais bai- 
xos em canas verdes e nas porçöes superiores de carlas velhas, verificou que a maior remoção de nitrogênio foi conseguida a pH 6,5, e em canas onde o teor de nitrogênio era alto devi-do a não maturação, a melhor clarificação foi obtida a pH abaixo de 7,0 . Os dados obtidos na eliminação de nitrogênio parecem indicar que o ponto isoelétrico se encontra entre 6,5 e 7,0 .

Ao contrário de DEER (1916), que ao submeter caldo de cana ao aquecimento durante 30 minutos e variando as quantidades de CaO para obtenção de diferentes pH na faixa de 6,9 a 9,4, observou uma percentagem maior de remoção do nitrogênio total a medida que o pH aumentava:

$\begin{array}{lc}\mathrm{pH} & \frac{\text { o de } \mathrm{N} \text { total removiảo }}{6,9} \\ 7,6 & 13,9 \\ 7,8 & 26,4 \\ 8,8 & 34,3 \\ 9,4 & 36,8 \\ & 43,4\end{array}$

PAYNE et alii (1928), tambëm concluiram que a eliminação de colöides é inquestionavelmente maior em altos valores de pH. Aumentos nas quantidades de cal causaram uma maior eliminação de colóides.

Segundo WIGGINS (1969), hā na cana proteinas de diferentes pontos isoelêtricos, já que algumas são separadas no processo cal-calor de clarificação, enquanto que outras: têm permanecido no caldo. 
Segundo VEGA (1957), o sedimento obtido em meio ácido é mais rico em proteínas que o obtido com tratamento alcalino

Ainda VEGA (1957), ao estudar a ação do calor sobre o caldo ácido na dupla clarificação, concluiu que 50\% das proteínas tiveram seu ponto isoelétrico em meio ácido e as 50 \% restantes em meio alcalino.

Ao se aquecer o caldo em meio alcalino, precipitam as proteínas de ponto isoelétrico alcalino, precipi tando só parte (a metade) das de ponto isoelétrico ácido, que por não estarem a pH apropriado, se hidrolisam em parte, . solubilizando-se.

Um balanço nitrogenado realizado numa Usina de Trindade, constatou que aproximadamente metade do nitrogê nio protéico solūvel originalmente presente no caldo misto, era removida durante o processo de clarificação (BENNETT,195ía).

SKOLA (1923), evidenciou que na caleagem a frio foi eliminado $3,9 \%$ do nitrogênio original presente, havendo um aumento para $5,7 \%$ pela adição de cal ao caldo a $80^{\circ} \mathrm{C}$. REVA e SIMAKHINA (1978), ao estudarem a relação entre $\mathrm{pH}$, \% $\mathrm{CaO}$ e o de remoção da proteína durante a de fecação a temperatura de $20-80^{\circ} \mathrm{C}$ durante 10 - 60 minutos, verificaram que a máxima remoção de proteínas foi observada a concentração de 0,12 - 0,13\% de $\mathrm{CaO}(\mathrm{pH} 11,4-11,6)$ tendo sido removido $90 \%$ da proteína a $80^{\circ} \mathrm{C}$ e $75-82 \%$ entre $20-40^{\circ} \mathrm{C}$.

LAPIN et alii (1978), ao clarificarem caldo de 
beterraba atravēs do esquema clássico, em que a concentração de cal total é de $2,5-3,5 \%$ de cao no caldo, e por um esquema em que parte dessa mesma concentração de cal foi adicionada a uma segunda defecação a 95 - $96^{\circ} \mathrm{C}$ por 0 - 20 minutos, verificou que a percentagem de remoção de não açūcares foi de $26-$ 27\% para o esquema clássico, e, acima de 36 - 37\% para o segundo esquema tanto em laboratörio quanto na usina.

De acordo com PAVLAS e HAUSLEROVA (1956), a de fecação e saturação removem em média 97,7\% das proteínas presentes e 59,6\% dos produtos de decomposição ou 91,4\% no total.

A decomposição alcalina durante a clarificação do caldo produz não somente albuminosas e peptonas, mas também peptídeos e aminoácidos.

Em experimento realizado por PEREZ et alii (1978), foi verificado que durante a clarificação houve uma redução do nitrogênio protéico como resultado de sua remoção durante o referido processo, podendo também produzir-se uma degradação das proteínas, que é manifestado por um aumento no teor de peptídeos de 0,155 (\% Brix x 10²) para 0,333 (\% Brix $\times 10^{3}$ ) no caldo clarificado.

Pesquisas realizadas por ZAKHAROV et alii(1983), demonstran que durante a principal defecação a $85^{\circ} \mathrm{C}$, cerca de 80\% do nitrogênio total é eliminado nos primeiros 5 minutos. A percentagem de eliminação global do nitrogênio através de vários esquemas de purificação é no máximo de $36,8 \%$. 
STEVENS (1955), constatou que cerca de 39,56\% das proteínas presentes no caldo misto são removidas durante a clarificação por çaleagem a quente, e os outros $60 \%$ do nitrogênio protéico,juntamente com nitrogênio amínico e de amidas passam para o xarope. Concluindo-se, que a maioria do nitrogênio que entra na usina passa para o melaço, que há pouca hidrôlise da proteỉna e aminoäcidos no processamento e que pouco nitrogênio da amida é liberado como amônia.

HONIG (1969), tambēm sugeriu que cerca de 60\% do nitrogênio presente no caldo de cana não são elimináveis durante o processo de defecação.

O fato dos compostos nitrogenados se acumularem no melaço é observaco quando se faz a dosagem do teor de nitrogênio no melaço.

Uma amostra de melaço da usina de Trindade foi analisada por WIGGINS (1969) quanto à concentração de nitro gênio, sendo encontrado o valor de 0,47\% dos quais $0,135 \%$ poderiam ser classificados como pertencentes a substâncias nitrogenadas coloidais, e,0,333\% a substâncias capazes de exis tir em solução verdadeira.

WIGGINS (1969), considerou que 80\% das albuminas foram eliminadas no tratamento pelo calor, porém SEIP (1928), afirmou que na defecação do caldo de cana se removeram somente $25 \%$ dos colóides de todos os tipos. 
Segundo DEER (1916), a quantidade de matéria co loidal que existe no caldo cru está nos limites de 0,02 e 0,29\%. A clarificação pode fazer com que essa quantidade aumente ou diminua, porém em média se consegue a eliminação apạ rente de 10 a 15\% (KING, 1931; PAYNE e KEANE, 1927; PAYNE et alii, 1928).

GUAún (1935), relata que no processo de defeca ção com cal, a percentagem de eliminação do colóide varia de 10 a $32 \%$ com uma média de $15,6 \%$

De acordo com PAYNE (1969) o nitrogênio removí do na clarificação pode variar de 12,5 a $60 \%$, porém a média geral de separação é de um terço. As proteínas são quase completamente precipitadas, ao passo que os aminoácidos simples permanecem em solução.

SPENCER e MEADE (1945), provaram que a eliminação de proteínas varia em diferentes variedades de cana e em diferentes métodos de clarificação. Com processo regular de defecação (caleagem a frio), a variedade BH 10 - 12 mostrou uma eliminação de 83\% da proteína e a POJ $287854 \%$, mas com o método de caleagem fracionada e duplo aquecimento, a variedade BH apresentou uma remoção de proteína de $94 \%$ e a POJ 2878 84\%.

Em estudo de FARNELL (1924), sobre o efeito da caleagem fria e com ebulição na remoção de proteínas no caldo ca cana, foi constatado uma maior precipitação (cerca de 23\%) 
na caleagem por ebulição que na caleagem a frio (cerca de 6\%).

Já GUAzON (1935) e KING (1931), afirmam que não há nenhuma vantagem em se aquecer o caldo antes ou após a caleagem, com relação à remoção de não açũcares.

Segundo SATYANARAYANA (1952), a quantidade de nitrogênio removido por vários métodos de clarificação, sob diferentes condições, têm sido relativamente constante: cerca de 30\% do nitrogênio total, presente no caldo de cana. Essa quantidade é aproximadamente a mesma que é removida através da ebulição do caldo de cana.

Assim, proteínas coagulāveis pelo calor são eliminadas, mas o teor de nitrogênio solũvel não protéico é inalterado (SATYANARAYANA, 1952).

De acordo com BENNETT (1957ai,50\% da proteína disponível no sistema (proteína dissolvida e adsorvida) é pre cipitada durante a ebulição.

HARDY (1927), tem assinalado que dos não açưcares presentes no caldo de cana, cerca de 9\% são proteínas, $9,5 \%$ aminoácidos e 15,5\% amidas de aminoācido. Os aminoácidos e suas amidas existem no caldo na forma de solução verdadeira, porém nesse meio as proteínas são coloidais. Quando o caldo de cana é clarificado através de cal e aquecimento, algumas das proteínas se coagulam e se separam durante a decantação, junto com os precipitados inorgânicos porém, outras permane- 
cem no estado coloidal.

VEGA (1957), observou que ao se aquecer um cal do a $100^{\circ} \mathrm{C}$, em que se fez um tratamento ácido, houve uma redução de nitrogênio protéico em torno de 46 partes por 100 partes de proteína e um aumento no teor de nitrogênio solúvel, concluindo-se que a redução do nitrogênio protéico se deve não a sua eliminação e sim a sua solubilização. Ao se efetuar a sua clarificação ácida a quente, elimina-se o mesmo nitrogênio que a frio, apesar do restante das proteínas elimi náveis que permanecem dispersas se hidrolisarem,passando a formar polipeptídeos ou talvez aminoácidos não elimináveis.

YADAV et alii (1982), constataram que a clarificação do caldo não afetou a produção de etanol. A velocidade de fermentação e rendimento aumentaram quando da adição de 200-1.000 ppm de uréia ou pela redução da borra de levedura.

$$
\text { SAIGAL E VISWANATHAN (1980), }
$$

ao estudarem o efeito da clarificação de melaços por diferentes métodos químicos na fermentação alcoólica, observaram um aumento na eficiência da fermentação em torno de 10 a $14 \%$.

Segundo BENNETT (1957a), certos açúcares, incluindo a sacarose, estabilizam as proteínas contra a precipitação. No aquecimento do caldo bruto, 50\% da proteina total solúvel não é precipitada, mas neste caso não é possível concluir que o efeito seja inteiramente devido à presença de sacarose; pode ser que algumas proteínas presentes no caldo não 
sejam coaguláveis pelo calor, na ausência de açūcares.

Entretanto, VASATKO e DANDAR (1971), afirmam. que aumentando-se o teor de sacarose numa faixa de 0-15\%, observa-se certo efeito benëfico na remoção de compostos nitrogenados, mas aumentos acima desses limites têm efeito oposto.

ZHURA e ZAGAIKEVITH (1967), ao submeterem uma solução contendo sacarose e concentrações conhecidas de glutą mina e asparagina à carbonatação com subsequente aquecimento a temperatura constante de 100,110 ou $120^{\circ} \mathrm{C}$, observaram que permaneceram na solução aproximadamente $80 \%$ da asparagina orị ginal, mas somente 14-25\% de glutamina original.

De acordo com BENNETT (1957b), a glutamina ë hidrolizada a ácido glutâmico durante o aquecimento em todos os valores $\mathrm{pH}$, podendo o mesmo processo ocorrer quando resi duos de glutamina fizerem parte da cadeia de polipeptídeos.

STANEK (1921), demonstrou que nas usinas que processam beterraba, os ácidos aspártico e glutâmico săo os que se precipitam, ao menos parcialmente, durante a defecação. As amidas, tais como a asparagina e a glutamina se decompõem durante o tratamento cal-calor, formando amoníaco e os correspondentes aminoācidos.

A variação do teor de polissacarídeos guarda certa semelhança com a variação no teor de proteínas até um pH 9, o que pode dever-se à formação de um complexo proteỉna- 
polissacarídeo, e a ação indireta sobre os polissacarídeos daqueles fatores que influenciam as proteínas (BENNETT, 1957).

BENNETT (195 Ђ), afirma que grande quantidade de polissacarídeos e proteínas foram encontrados no sedimento centrifugado do caldo bruto, sendo o teor de nitrogênio total determinado pelo método de Micro-Kjeldahl, da ordem de $10 \mathrm{mg}$.

O referido autor também relata, que polissacarídeos solúveis presentes no caldo de cana não são removidos sob condições de defecação.

As condições de colheita (tempo chuvoso ou se- . co) influenciam na composição do material que causa turbiảez em caldos de cana já clarificados: em caldos defecados de uma variedade colhida em tempo seco, 78\% do material no sedimentą dọ centrifugado era orgânico e 8\% era sílica; enquanto a mes-ma variedade colhida após período chuvoso apresentava uma tụ bidez constituída de 4lo de sịlica e 42\% de material orgânico, sendo que a proporção de proteína em relação a outros materiais foi de 28\% (FORT e SMITH, 1954).

Ainda de acordo com FORT e SMITH (1954), o nitrogênio ou proteína presentes no precipitado após centrifugą ção do caldo previamente clarificado, está numa concentração relativamente pequena, pois a maioria do nitrogênio permanece no caldo como aminoácidos e amidas solúveis. 
Segundo DOBRZYCKI (1982), 30-40\% da eliminação de não sacarose durante a purificação pode decrescer para $25 \%$ se a chuva for escassa durante a vegetação tardia, levando o caldo bruto a apresentar alto brix, baixa pureza, alto teor de nitrogênio, particularmente $\mathrm{N}$-amida.

Não somente a clarificação por métodos químicos é capaz de promover a eliminação de material proteināceo do caldo; métodos físicos tais como a centrifugação possibili. tam tais remoções.

VIGNES e FROBERVILLE (1960), ao submeterem

o

caldo de cana a centrifugação a $3.800 \mathrm{rpm}$ constataram uma remoção de cerca de 30\% das proteỉnas presentes.

SHUKLA e PRABHU (1961), ao centrifugarem caldo de cana a $3.000 \mathrm{rpm}$, observaram que cerca de $0,7 \mathrm{~g} / \mathrm{l}$ de proteína permanecem em solução.

SAIGAL e VISWANATHAN (1980), promoverem a centrifugação de melaços não clarificados por 30 minutos a 10.000 $r$ p m, verificaram uma redução no teor de sölidos totais em cerca de 2\% em relação ao decantado.

BENNETT (1957b), ao estudar o precipitado obtido pela centrifugação de amostras de caldo de cana,observou que o material proteináceo adsorvido na superfície de partículas cerosas não é removido pela lavagem do centrifugado. 
Como outros não açūcares orgânicos e inorgânicos, os aminoácidos são também removidos em diferentes proporções durante os vários processos da clarificação do caldo de cana.

Segundo SHARMA e JOHARY (1984), pouca atençäo tem sido dada ao componente dos aminoácidos durante o curso da clarificação; nenhum estudo sistemático e detalhado tem sido feito a respeito da variação do nível de aminoácidos.

De acordo com REINEFELD et alii (1982), há sem exceção uma redução no teor de aminoácidos durante a clarifí cação do caldo. Alguns aminoácidos como a ornitina e lisina, que tomam parte preferencialmente na reação de Maillard, têm um decréscimo muito grande.

Amostras de lodo contém cerca de 50\% do total de aminoácidos eliminados durante a clarificação do caldo.

SHARMA e JOHARY (1984), verificaram que cerca de $24 \%$ do total de aminoácidos presentes no caldo misto, podem ser eliminados através de uma simples defecação. Esse fato pode ser devido à remoção de uma categoria particular de aminoácidos, juntamente com a matéria coloidal que tendo um ponto isoelétrico nạ faixa de pH 5,5 e 7,0 poderia ser coagulado ao se trazer o pH do caldo misto a 7,0.

Um outro aspecto observado é que a remoção de 
aminoācidos durante a sulfitação, aumentou à medida que se aụ mentou a concentração de $\mathrm{CaO}$ de 0,58 a 48 , sendo que a maior remoção de aminoācidos (42\%) foi observada a 2\%; a partir desse valor, a retirada de aminoācidos permaneceu mais ou menos constante. Essa pequena variação é atribuída a alta solu bilidade dos aminoácidos na presença de quantidades crescentes de leite de cal e/ou a uma menor velocidade de formação de melanoidinas, na presença de grandes quantidades de sulfito de cálcio no precipitado e/ou no estado dissolvido.

Os mesmos autores, tambëm constataram que ao se reduzir o $\mathrm{pH}$ do caldo misto $\mathrm{com} \mathrm{SO}_{2}$, antes da caleagem, grande quantidade de aminoācidos foi removida, atingindo valores próximos a $50 \%$ a pH 4,0. Isto pode ser devido à floculação de um grande nümero de colóides liofílicos sob condições ācidas e os aminoācidos presentes podem ter sido removi dos juntamente com esses colóides. Esta suposição è baseada na observação de que a maioria das substâncias contendo nitrogênio em caldo ảe beterraba são floculadas em meio ãcido. Verificou-se, ainda, que a máxima eliminação de aminoācidos ocorreu em caldos mistos que apresentaram uma concentração de $400 \mathrm{ppm}$ de $\mathrm{P}_{2} \mathrm{O}_{5}$. Valores menores que este, exibiram uma eliminação baixa, enquanto níveis de fosfato maiores que 400 ppm não revelaram um aumento significativo na percentagem de remoção.

Caldos deficientes em fosfato caracterizamse por apresentar alta concentração de aminoācidos. Com relação ao pH, observaram maior remoção 
de aminoácidos a pH 6,5 durante a pré-caleagem do caldo misto uma menor remoção em meio básico (pH 7 e 8) em relação ao con trole; podendo esse fato estar associado com a coagulação de certos colóides próximo àquel.e pH. Segundo ROBERTS e CASERIO (1965), um grande número de aminoācidos tem seu ponto isoelé trico na faixa de $\mathrm{pH} 5,5$ a 6,5 e não em pH alcalino. Além disso, a maior solubilidade de muitos aminoăcidos em meio alcalino, como indicado por OLBRICH (1963), poderia também contribuir para sua menor remoção a pH 7-8 durante a pré-caleagen.

A variação no teor de aminoácidos durante diferentes processos de clarificação, foi estudado em laboratō rio, por SHARMA e JOHARY (1984), sendo que o processo de sulfitação foi o que removeu maior percentagem de aminoácidos, seguido pela carbonatação ou defecção. A pré- caleagem removeu cerca de $49,6 \%$ de aminoácidos.

KUBADINOW e HAMPEL (1975), pesquisando a degradação de aminoácidos durante a clarificação do caldo, constataram que quase todos os aminoácidos sofreram degradação; então, não se pode esperar encontrar aminoācidos no melaço, da mesma forma que ocorre no caldo bruto. Glutamina e asparagina foram os que mais sofreram hidrólise. As alterações nas con centrações dos aminoácidos resultaram tanto de reação química quantio do fenômeno da adsorção.

Segundo SULLIVAN (1978), a taxa de degradação da glutamina após caleagen do caldo de beterraba foi estimada em $40 \%$. 
De acordo com AGARWAL e JOHARY. (1974), a con centração de aminoácidos total em caldos brutos ou clarificados, diferem grandemente entre usinas e variedades de cana. Clarificação por sulfitação remove 20-30\% dos aminoácidos, a inclusão de pré-caleagem com ou sem adição de fosfato aumen tou essa remoção.

RODRIGUEZ et alii. (1979), ao submeterem xarope de cana ao aquecimento a temperaturas de $70-100^{\circ} \mathrm{C}$, em meio alcalino (pH 7-10) durante 1-5 h, evidenciaram uma redução no teor de aminoácidos em 30-80\% e conversão de açūcares reduto res a ácidos orgânicos, aumentando a ação tampão.

2.2.2. Fosfatos

O fósforo é considerado um dos elementos mais importantes para obtenção de uma clarificação eficiente do caldo de cana, pois contribui para formação de compostos praticamente insolúveis, responsáveis pela adsorção, aprisiona mento e arrastamento das impurezas presentes no caldo (DELGADO et alii, 1973a; KLAN, 1965).

A extensão em que os colóides do caldo podem ser eliminados por adsorção, depende da quantidade do precipitado de fosfato de cálcio formado, e que por conseguinte depende da concentração de ions fosfato no caldo (GUPTA e PRASAD, 1967; JANAKIRAMAIAH et alii, 1967; BOND, 1925). 
PAYNE et alii. (1928), em experimentos feitos duㅡ rante os meses de janeiro a maio, verificaram que os caldos crus variavam consideravelmente na composição particularmente quanto ao teor de fosfato. O fosfato, sendo um constituinte im portante na clarificação por defecação, mostrou uma relação linear com relação à eliminação de colóides. O aumento na eliminação dè colóides com altos teores de fosfato era acompa nhado por um aumento no peso e volume de lodo.

Todos os compostos de fosfato no caldo, que são prontamente capazes de fornecer íons $\mathrm{PO}_{4}^{-}$, são ditos disponí veis ou efetivos. Segundo Rao e Shankar (1940), citados por JANAKIRAMAIAH et alii (1967)rsomente os fosfatos em solução verdadeira ou aqueles que entram em soluŗão durante o aquecimento do caldo, são realmente efétivos, já que somente esse fosfato irá reagir com CaO adicionado.

Segundo SPENCER e MEADE (1945), durante as ope rações de clarificação do caldo, parte do fosfato considerado na forma orgânica pode se hidrolisar, tornando-se disponível.

De acordo com JANAKIRAMAIAH et alii (1967), o teor de fosfato inefetivo ë geralmente baixo, mas quando o total de fosfato é também baixo, o inefetivo pode atingir a metade do total.

o caldo deve apresentar um teor mínimo de 300$350 \mathrm{mg}$ de $\mathrm{P}_{2} \mathrm{O}_{5} /$ litro, para que o mesmo clarifique eficientemen 
te (BENNETT e RAGNAUTH, 1960; HONIG, 1960; GUPTA et alii,1965; JANAKIRAMAIAH et alii, 1967; PAYNE, 1969; DELGADO et alii, 1973a; SILVA Jr., 1976 ).

Tem-se observado que o teor de fósforo de muitas variedades de cana estão sempre aquém do preconizado na literatura (BENNETT e RAGNAUTH, 1960; CESAR et alii, 1972; DELGADO et alii, 1973b;CESAR et alii, 1974; GUIMAR ̃̃ES e SILVA; 1976; SILVA Jr., 1976).

Segundo WALKER (1923), SALINAS (1946) e SHARMA et alii (1981), uma adubação fosfatada contribui para o aumento de $\mathrm{P}_{2} \mathrm{O}_{5}$ no caldo, aumentando a eficiência da clarificação, sendo ainda muito mais efetivo que aquele adicionado no processo de clarificação.

O processo de clarificação se baseia, fundamentalmente, na precipitação de fosfato de cálcio em determinadas condições de pH e temperatura. O precipitado arrasta os não açūcares presentes, ao mesmo tempo que atua como adsorvente dụ rante o processo (PEREZ e GUTIERREZ, 1977).

BENNETT e RAGNAUTH (1960), sugerem que são esta belecidas ligações entre fosfato de cálcio e partículas adjacentes; a união das partîculas ao precipitado ocorre através de íons $\mathrm{Ca}^{2+}$, os quais são ainda ligados à superfície da partí cula pela proteína adsorvida. O número de partículas floculan tes depende da quantidade de fosfato precipitado, havendo, 
portanto, um nível de fosfato abaixo do qual uma completa flo culação não poderá ser atingida.

HONIG (1950), estudando o comportamento do fósforo no processo de clarificação, constatou que durante a caleagem do caldo há maior precipitação desse elemento na forma de fosfatos insolúveis de cálcio e magnésio entre pH 6,8 7,8 , devendo ocorrer a precipitação máxima de $\mathrm{P}_{2} \mathrm{O}_{5}$ em torno do $\mathrm{pH}$ 7,5 com valores mais altos, conforme o pH da caleagem aumente ou diminua, em relação ao referido valor.

Análises feitas por KING (1931), em caldos que sofreram caleagem a $\mathrm{pH} 9,5$ ou 10 e, posteriormente, foram tratados com ácido acético a fim de reduzir a alcalinidade, para determinar a redissolução da matéria precipitada e a influência do ĩon cálcio, foi observado que havia uma maior eli minação de fosfato a um determinado pH, quando excesso de íon cálcio estava presente. Abaixo do pH 7,5 havia uma rápida redissolução dos fosfatos. Também foi constatado que se o caldo for caleado a altos valores de $\mathrm{pH}$ e a alcalinidade for reduzi da durante o aquecimento e sedimentação, os fosfatos ressolubilizarão, se o precipitado não for removido.

A precipitação de fosfatos parece ser uma fun-ção de ambos: concentração de íon hidrogênio e quantidade de íon cálcio.

Segundo DEBEN (1976), o processo de precipita - 
ção é çontrolado pelo equilíbrio da reação:

$$
\mathrm{Ca}^{2+}+\mathrm{HPO}_{4}^{-2} \rightleftarrows \mathrm{aHPO}_{4}
$$

como primeira etapa da reação. Esta reação pode proceder muito rapidamente da esquerda para direita, devido a sua característica puramente iônica. O fosfato de cálcio sólido assim formado é um precipitado instável e incompatível com a fase de. solução. Uma secundária e mais lenta reação ocorre entre as duas fases, em que o sólido fixa sobre si mesmo ou co-preci pita uma metade adicional ou suplementa a retirada de cálcio da solução.

Segundo HONIG (1969), o fosfato inorgânico adi cionado ao caldo é 99\% precipitado pela caleagem a pH 8,5, mas o fósforo presente na cana planta é 90\% precipitado. Para canas fisiologicamente velhas e canas ácidas, a precipitação é ainda maior. Estes resultados indicam que na cana normal, cerca de 10\% do fósforo, não eștá na forma de fosfato iônico e sim provavelmente presente em um número de compostos orgânicos.

Em análises feitas por GRUSzECKA (1983), em caldo clarificado, foi verificado que este continha cerca de $60 \mathrm{ppm}$ de $\mathrm{P}_{2} \mathrm{O}_{5}$, sendo a proporção de fósforo inorgânico para orgânico de 0,5 para 1,3.

Foi demonstrado por HONIG (1952), que o teor de fosfato orgânico em caldos clarificados, em Java, foi de 
20-30 mg de $\mathrm{P}_{2} \mathrm{O}_{5} /$ litro, estando grande parta. presente como hexosesfosfato. A concentração de fosfato inorgânico foi de

Ainda de acordo com HONIG (1952), a concentração de fosfato dissolvido em solução de sacarose pura, com 10-20 $0^{\circ}$ Brix, após adição de fosfato inorgânico e precipitação com leite de cal a pH 6,5 a 7,0 ou 8,0 foi de apenas poucos mg/litro, a pH 6,0 após ebulição e sedimentação, o fosfato dissolvido não é maior que $10 \mathrm{mg} \mathrm{P}_{2} \mathrm{O}_{5} /$ litro.

\subsection{Microorganismos.}

\subsubsection{Leveduras}

Segundo MORRIS (1958), um suprimento extracelular de material nitrogenado é essencial para contínua produção de novo protoplasma e as leveduras geralmente obtêm este elemento, de substâncias relativamente simples, tais como: sais de amônio, aminoācidos, nitratos e amidas, embora hajam evidências de que dipeptídeos e polipeptídeós possam também ser assimilados.

Segundo STUPIELLO e HORII (1981), quando há uma limitação de nitrogênio, o crescimento celular é diminuído e, como consequência, uma significativa parte de glicose poderá ser convertida em glicogênio, além do fato de que em ausência de nitrogênic a velocidade de fermentação diminui, aumentando 
consequentemente o tempo de fermentação e diminuindo a produtividade.

O nitrogênio deve aparecer em niveis da ordem de 300-350 ppm de nitrogênio total, ocorrendo um residual da ordem de 30 a 50 ppm de nitrogênio total.

O teor de nitrogênio nas leveduras è cerca de $10 \%$ do peso da matéria seca e como tal, representa um importante constituinte no meio (JONES et alii, 1981).

E'm experimento realizado por WICKERHAM (1945), utilizando 1.700 linhagens de leveduras, foi observado que todas as linhagens são capazes de utilizar três fontes de nitrogênio: sulfato de amônio, uréia e asparagina.

Comparando a influência de diferentes sais de amônio no crẹcimento da levedura, PIRSCHALE (1930), constatou que o di-amônio-fosfato promove o crescimento da levedura mais eficientemente. Sendo também utilizado com facilidade e bom aproveitamento os seguintes sais de amônia: fosfato; bicar bonato, acetato, lactato e tartarato de amônio; mono, di e tri-amônio fosfato. O cloreto de amônio tem se mostrado inferior a outros sais de amônio.

Em ensaio realizado por FULMER et alii. (1921), para determinar a melhor concentração dos vārios sais de amônio para o ótimo crescimento da levedura, foi observado que o cloreto, sulfato, nitrato e tartarato de amônio apresentaram 
a mesma concentração ôtima, que é aquela ccnçentração de sall correspondente ao valor calculado de 0,060\% de amônía, sendo portanto dependente somente da concentração do cátion. Todos os 4 sais se mostraram igualmente efetivos para o crescimento da levedura.

JONES et alii (1981), postulam que as leveduras são capazes de utilizar íons amônio como ūnica fonte de nitrogênio, embora algumas leveduras requeiram adição de aminoācidos específicos.

O sulfato de amônio é a fonte de nitrogênio mais utilizada nas fermentações industriais.

Segundo SMYTHE (1939), a asparagina e glutamina exercem um efeito estimulante nás células de levedura semethante aos sais de amônio. Sendo evidenciado que $\mathrm{N}_{4}^{+}$reduz o período de indução em meio glicosado fermentado por extrato de levedura.

A assimilação de fontes de nitrogênio por 16 culturas de Sporotrichium schenenckii, na fase leveduriforme, foi estudada por MINAMI (1975), sendo utilizados como fontes de nitrogênio, uréja, cisteína, glicina, triptofano, nitrato de potássio, sulfato de amônio, peptona e asparagina. A pepto na, asparagina e sulfato de amônio foram assimilados por 15 das 16 culturas. A uréia, cisteína e glicina por 14 e o nitra to por 7 culturas somente. O triptofano não f́oi assimilado por nenhuma cultura. 
O valor nutritivo de 25 compostos químicos como fonte de nitrogênio para duas linhagens de levedura foi pesquisado por THORNE (1933) sendo evidenciado que a asparagi na, ácido aspártico e fosfato de amônio eram igualmente efetí vos. Uréia e ácido ūrico foram considerados mediocres.

Já SCHULTz e POMPER (1948), afirmam que a uréia é uma fonte de nitrogênio tão efetiva quanto o sulfato de amốnio. Segundo SUOMALAINEN e OURA (1971), REED e PEPPLER (1973), S. cerevisiae é incapaz de assimilar nitrato e nitritos.

SURDIN et alii (1965), constataram que os ions amônio inibem a absorção de aminoácidos e, consequentemente, quando a amônia é usada na propagação comercial, alguns amino ácidos presentes não são eficientemente removidos do meio.

HARTELIUS (1938), postula que na presença de sulfato de amônio, a levedura assimila amino e amido-nitrogênio de ácido aspártico e asparagina duas vezes mais rápido que o nitrogênio amoniacal obtido de sais de amônio.

De acordo com THORNE (1949), em meio que contenha aminoácidos e sal de amônio, o consumo de nitrogênio amíni co é 1,5 vezes mais rápido que o nitrogênio da amônia.

Entretanto, BURKHOLDER et alii (1944), evidenciaram que mistura de aminoácidos são uma fonte de nitrogênio mais eficiente que İons amônio, sendo a assimilação de nitrogênio 
de aminoácido 5 a 10 vezes a de nitrogênio amoniacal.

Purinas, pirimidinas e peptídeos são pronta mente assimilados pelas células de levedura aumentando a produção de biomassa (BURKHOLDER et alii, 1944 e SCHULTz et alii, 1949).

Greve (1960), citado por ARAOJO (1970), baseado em experiência de multiplicação de leveduras, evidenciou que a assimilação do nitrogênio é sincrônica à síntese de prọ teínas e reprodução celular.

VAIRO et alii (1975), ao adicionarem concentração conhecida de sulfato de amōnio em cultura contínua de Sacharomyces cerevisiae, observaram um aumento considerável na concentração microbiana, indicando que a fonte de nitrogênio era o fator limitante do crescimento do microorganismo.

WILLIAMS et alii (1940), e BURKHOLDER et alii (1944), afirmam que fontes de nitrogenadas complexas, tais como mistura de aminoácidos, peptídeos, ácidos nucléicos têm produzido um aumento na concentração celular e fermentação pelas leveduras.

Segundo NIELSEN (1935), a levedura assimila cer ca de 40-50\% do nitrogênio total do mosto, sendo este princi palmente nitxogênio amínico.

Em ensaios de fermentação alcoólica realizados 
por MAGALHÃES et alii (1980), a adição de sulfato de amônio ou de uréia ao mosto de melaço acarretou aumento, tanto

na quantidade de proteína produzida pela levedura quanto da produtividade em etanol, e a produção celular é máxima quando a concentração de nitrogênio adicionada ao mosto como sulfato de amônio ou uréia é de 0,6 g/l. Acima desse valor, a biomassa produzida é praticamente constante. Ao estudarem a influên cia da concentração de nitrogênio adicionado na forma de sulfato de amônio e uréia no tempo de fermentação, observaram que aumentando-se a concentração de nitrogênio, o tempo de fermentação diminuía em cerca de $5 \mathrm{~h}$.

No mesmo experimento, constataram que aumentan do-se a concentração de uréia ou sulfato de amônio no mosto a ser fermentado o teor de etanol permaneceu constante: cerca de $7^{\circ}$ e $6^{\circ}$ GIs, respectivamente.

Segundo MASSART e HORENS (1952), em presença de limitadas concentrações de glicose (l mg) a adição de sais de amônio (l mg) produz uma estimulação ao consumo de oxigê nio pela levedura, quando comparados ao meio contendo apenas glicose, que é açompanhada pela assimilação do nitrogênio amo niacal. O mesmo ocorrendo para os aminoácidos glutamina, ácido aspártico e alanina.

Tsumura e Sato (1961), citados por ARAOJO(1970), afirmam que a atividade de fermentação da sacarose aumenta com a assimilução do nitrogênio. 
Contudo, LITVINENKO et alii (1980), afirmam que aumentos na concentração de $\mathrm{NH}_{4}^{+}$em meio de multiplicação de Candida utilis, levam a uma redução na taxa de absorção de glicose e crescimento da levedura.

HARRISON E GRAHAM (1970), ao estudarem O efeito da fonte de nitrogênio na eficiência da fermentação alcoólica, observaram que maior eficiência foi obtida ao se utilizar uma mistura de aminoācidos como fonte de nitrogênio (96\%), seguido do tratamento que não recebeu nitrogênio $(93,1 \%)$ e, finalmente, o tratamento com sais de amônio $(90,5 \%)$.

Em ensaio realizado por ARAOJO (1970), sobre a adição de sulfato de amônio em melaças anômalos ou deficientes, foi observado um aumento no consumo de açúcar pela levedura, velocidade de fermentação e produção de álcool. Em mela ços normais, a velocidade de fermentação com ou sem adição da fonte de nitrogênio,foi praticamente a mesma: a vantagem na eficiência, cerca de 7\% deve sér balanceada contra o custo da adição de sulfato de amônio.

ZAGO (1982), ao estudar o efeito da suplementação de nitrogênio em mosto de xarope, observou que após 22 horas de multiplicação, a quantidade de matéria seca produzida não aumentou nas doses superiores a 200 ppm de nitrogênio para a levedura Fleischmann.

Ainda, segundo ZAGo (1982), o nitrogênio foi 
- elemento que mais afetou a produção de matéria seca nas leveduras Fleischmann, IZ-1904 e M-300-A, tanto em mosto de xarope quanto no de melaço, ficando evidenciado que a levedura comercial Fleischmann è a mais exigente em nitrogênio.

SILVA (1983), ao fazer adubação do sorgo sacarino com nitrogênio na forma de sulfato de amônio, verificou que a partir de $60 \mathrm{~kg}$ de $\mathrm{N} / \mathrm{ha}$, houve decréscimo na produção de massa celular.

Ainda, segundo SILVA (1983), existem formas de nitrogênio absorvidas pela planta que não são assimiladas pela levedura.

De acordó com SILVA (1983), a adição de doses crescentes de nitrogênio no solo com sorgo sacarino, revelou um aumento no teor de nitrogênio na massa celular com redução na biomassa produzida, justificando-se a existência de menor quantidade no substrato, de nitrogênio metabolizável pela levedura.

Ao comparar os tratamentos que receberam adução nitrogenada sem suplementação de sais no substrato com que receberam suplementação, constatou que houve uma tendência do tratamento sem suplementação superar em rendimento fermentativo äquele que recebeu suplementação.

o fósforo é elemento essencial tanto para a fermentação como para crescimento, serdo muito importante no metabolismo de carboidratos devido ao mecanismo de acúmulo, 
transferência e liieração de energia, atravēs de ligações fos fóricas de alto nível energético. Para que ocorra uma fermentação alcoólica de bom rendimento, o fósforo deverá se $R$ encontrar nos nïveis de 125-150 ppm de $\mathrm{P}_{2} \mathrm{O}_{5}$ (STUPIELLO e HORII, 1981).

ATKIN et alii (1962), trabalhando com diferentes nívej.s de íon fosfato em meio sintētico, demonstrararn que uma concentração de $0,0018 \mathrm{M}\left(1,280 \mathrm{mg} \mathrm{P}_{2} \mathrm{O}_{5} / 1\right)$ era satisfatório para ótimo crescimento e fermentação.

Segundo Rothstein (1961), citado por SUOMALAINEN E OURA (19?1), a levedura absorve o fosfato como ânion monovalente, $\mathrm{H}_{2} \mathrm{PO}_{4}^{-}$.

A forma iônica do fosfato varia com o pH do meio, sendo que a pH 4,5 o íon fosfato se encontra totalmente na forma $\mathrm{H}_{2} \mathrm{PO}_{4}^{-}$que é ótimo para a enzima invertase e também para fermentação alcoólica (AMORIM, 1977).

De acordo com JONES et alii (1981), o fósforo como $\mathrm{H}_{2} \mathrm{PO}_{4}^{-}$que è essencial para crescimento celular e é requerido em concentrações em torno de 0,6 mM/g de células para uma ótima velociçade de fermentação.

STUPIELLO e HORII (1981), relatam que mostos, principalmente os de caldo e mistos, têm apresentado teores variáveis de $\mathrm{P}_{2} \mathrm{O}_{5}$, via de regra, superiores ao necessärio, que pode ser constatado inclusive pelos teores que surgem na vinhaça e que têm variado de 20 a $90^{\circ}$ ppm de $\mathrm{P}_{2} \mathrm{O}_{5}$. 
LEVANDOVSKII et alii. (1981), ao adicionarem

$\mathrm{H}_{3} \mathrm{PO}_{4}$ ao mosto de melaço, constataram uma ativa multiplicação da levedura que resultou num acúmulo de alto teor de etanol: 9,24\%. A adição de $\mathrm{P}$ e $\mathrm{N}$ (uréia) no meio de fermentação resultou na produção de uma menor concentração de álcool: 9,17\%. A produção de etanol na ausência de ambos os elementos foi de $9,10 \%$

Dados obtidos por ARAOJO (1970), durante a fermentação de mostos de melaço de cana, revelaram que a adição de $0,6 \mathrm{~g} / 1$ de $\mathrm{Na}_{2} \mathrm{HPO}_{4} \cdot 12 \mathrm{H}_{2} \mathrm{O}$ produziu uma massa celular de $0,203 \mathrm{~g} / 100 \mathrm{ml}$ quando comparados a produção de $0,84 \mathrm{~g} / \mathrm{l}$ sem suplementação. O melhor resultado foi obtido com adição de $0,5 \mathrm{~g} / \mathrm{l}$ de $\left(\mathrm{NH}_{4}\right)_{2} \mathrm{SO}_{4}+0,6 \mathrm{~g} / \mathrm{l} \mathrm{Na}_{2} \mathrm{HPO}_{4^{\prime}}$ em que a produção de biomassa foi de $0,564 \mathrm{~g} / 100 \mathrm{ml}$.

FULMER et alii. (1921), trabalhando com meio sin tético, observaram que adição de fosfato em concentrações acima de 0,6\% não causava aumentó na biomassa.

Em ensaios realizados por MAGALHÃES et alii (1980), foi coṇstatado que a adição de fosfato de sódio não influiu no aumento de produção da proteína celular.

De acordo com ZAGO (1982), o fósforo influenciou significativamente na produção de matéria seca da levedura Fleischmann, na dose de 75 a 150 ppm, quando comparadas com o tratamento não suplementado em fósforo. Nas leveduras IZ-1904 e M-300-A, embora houvesse um aumento de matéria seca 
nas concentrações mencionadas,este não foi significativo.

SILVA (1983), observou um decréscimo na massa celular produzida após 7 horas e 22 horas de multiplicação a partir do tratamento com $100 \mathrm{~kg}$ de $\mathrm{P}_{2} \mathrm{O}_{5} /$ ha em isorgo sacarino.

Ao analisar os tratamentos que receberam nitrogênio e fösforo no substrato e confrontando-os com os resultados dos tratamentos que não receberam suplementação, constatou que houve tendência do tratamento sem suplementação superar em rendimento àquele que recebeu suplementação.

\subsubsection{Microflora do Caldo Tratado Termicamente}

O caldo de cana-de-açūcar é um excelente substrato para o crescimento de microorganismo por ser rico em ma téria orgânica e inorgânica. A contaminação bacteriana è um fato comprovado na maioria das destilarias de älcool, podendo ocasionar uma queda de produtividade da fermentação.

Foi constatado por ALTERTHUM et alii (1984), perdas em termos de rendimento em etanol, da ordem de 20 a 98\% do teórico, quando a concentração bacteriana variou de $5,5 \times 10^{7}$ a $4 \times 10^{9}$ células $/ \mathrm{ml}$.

Em trabalho realizado por AMORIM et aliii (1981), foi verificado que as bactéxias contaminantes podem afetar o rendimento alcoólico reduzindo-o a níveis de 55\% do teórico. 
TILEJRY (1968), isolou da cana colhida bactérias do ácido lático como I. mesenteróides, L. casei, Lactobacillus plantarum, Lactobacillus var. alactosus, Lactobacillus sp. (heterofermentativos), bactērias gram negativas, ácidos tolerantes e $\underline{B}$. subtilis.

Para CLARKE et alii (1980), os microorganismos importantes na contaminação do caldo de cana desde o campo até a usina, são as bactérias produtoras de ácido butírico, Clostridrium termosaccharolyticum alēm do $\underline{\text { L. mesenteroides }}$ e L. dextranicum e leveduras do tipo Saccharomyces.

Há muitos fatores que afetam a deterioração da cana-de-açúcar após colheita: temperatura, umidade, matum ração, variedade, período de armazenagem, condições da cana, tempo após a queima, tipo de colheita (GUPTA et alii, 1968 e SILVA, 1974).

BEVAN e BOND (1971), demonstraram que a microflora da cana verde é extremamente variada e, aproximadamente, 50 microorganismos diferentes foram isolados. Leuconostoc foi encontrado especialmente sob a bainha em companhia de pe-lo menos três gêneros de leveduras, Saccharomyces, Torula e Pichia. Bacilos do solo, em particular, Bacillus cereus e

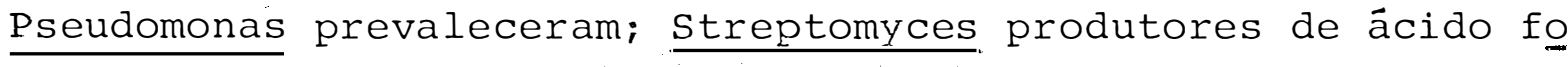
ram observados, fungos e Actinomycetes estavam tambëm presentes em grande número. Todos esses organismos metabolizam açúcares e uma grande proporção é termoresistente, crescendo bem 
em temperaturas de $50-55^{\circ} \mathrm{C}$.

A microflora presente nas fendas das canas ver. des consistia na maioria de cocos, principalmente Leuconostoc, espécies da levedura Saccharomyces e uma grande variedade de fungos, e àlguns bastonetes produtores de ácido lático.

Todos esses microorganismos são muito ativos, e o crescimento nessas fendas aparentemente atua como exce lente sítio para multiplicação, mesmo após a queima da cana.

\section{Dezessete microorganismos diferentes foram} isoladaos da superfície de canas queimadas, alguns em até 10 minutos após a queima ter ocorrido. Tais microorganismos eram predominantemente bastonetes. Dos bastonetes isolados, cinco eram extremamente termoresistentes e a maioriá utilizava açúcares.

Testes realizados nas ceras da cana, dão alguma indicação que certas frações de cera são em algum grau bacteristáticas. Supõe-se que a remoção de parte dessas ceras pelo calor durante a queima de cana, permita que microorganismos cresçam mais livremente; caldos obtidos de colmos de cana após a queima, são um excelente meio de crescimento para microorganismos.

Ainda, BEVAN e BOND (1971), constataram que os microorganismos presentes no caldo misto: Leuconostoc e leveduras estão naturalmente em grande número, sendo característị cos de organismos provenientes da móagem da cana, que por se- 
rem capazes de resistir a temperaturas relativamente mais elevadas do que a maioria dos outros contaminantes, predominam no caldo misto.

MCNEIL e INKERIMAN (1977), constataram a presença de bactérias no tecido interno das canas queimadas, aparentemente sadias. As espécies citadas foram: Erwinia uredovora, Erwinia herbicola, Enterobacter cloace, Leuconostoc mesenteroides, Klebsiella pneumoniae, Enterobacter aerogenes, Enterobacter sp., sendo detectada uma população que variou de $1,0 \times 10^{4}$ a $1,7 \times 10^{6} / 9$ de tecido.

Já SANHUEZA (1979), verificou que a população bacteriana interna da cana sadia, proveniente de gemas trata das termicamente e cultivadas em solo autoclavado foi de $3,2 \times 10^{5} / \mathrm{cm}^{3}$ de tecido interno da planta. A frequência de Erwinia herbicola, atingiu 10: da população detectada, existindo porém outras colônias de igual ou maior frequência que não foram identificadas.

Segundo BROCK (1967), microorganismos podem adaptar-se a temperaturas de $90-100^{\circ} \mathrm{C}$, tendo sido isolados de lamas vulcânicas superaquecidas, assim de acordo com BEVAN e BOND (1971), é possível que microorganismos vivam e se reproduzam na natureza em temperaturas excepcionais. Isto poderia explicar a presença de tais organismos como A.ctinomycetes termofílicos, organismos semelhantes na aparência e cá racterísticas bioquímicas ao Leuconostoc, e numerosos baci- 
Los encontrados no processamento de líquidos após aquecimen to e caleagem.

Winders e zemek, citados por BEVAN e BOND (1971), relataram a presença de bastonetes esporulados em caldos clarificados a temperaturas próximas de $100^{\circ} \mathrm{C}$. Tais microorganismos estavam presentes em amostras coletadas de decantadores a $92^{\circ} \mathrm{C}$. Utilizam glicose, sacarose, manitol, amido e produzem ácido lático. Sua temperatura ótima de mul tiplicação está entre $80^{\circ} \mathrm{C}$ e $85^{\circ} \mathrm{C}$ e não se desenvolvem a temperaturas inferiores a $50^{\circ} \mathrm{C}$, sendo identificados com $\underline{B}$. megatherium:

RODINI (1985), verificou o aparecimento de CO lônias pigmentadas de Bacillus megatherium somente em caldos que sofreram tratamento térmico.

A presença de microorganismos termofilicos que são viáveis sob condições de temperatura extremamente elevadas poderia indicar que a interrupção do crescimento microbiano em produtos líquiclos pode não cessar nos trocado res de calor e que, embora após aquecimento e caleagem perdas adicionais insuspeitáveis podem estar ocorrendo.

BLISS e MADON (1946), também relataram a ocor rência de microorganismos mesófilos, em vārias amostras de caldos decantados de clarificadores Seip e Dorr, embora a contagem fosse muito pequena. 
Kent, citado por BLISS e MDAON (1946), notou que parece haver algum tipo de correlação entre a turbidez de caldos decantados e filtrados com suas contagens bacterianas, especialmente com a contagem de termofilicos. Similarmente, caldos com alto grau de claridade tendem a eliminação de termofílicos.

Em ensaio realizado por LUCREDI et alii (1984), para verifjcação de um sistema de tratamento térmico do cal do de cana, foi constatada a presença de microorganismo com contagem total em PCA no valor máximo de $9,5 \times 10^{4}$ e mínimo de $6,4 \times 10^{3}$ em caldos saidos do aquecedor tubular operando à temperatura de $115^{\circ} \mathrm{C}$ sendo, portanto, evidenciado uma bai xa eficiência do conjunto para produzir um caldo com baixo nível de microorganismos. Houve reprodução de microorganismos nos trocadores, principalmente de bactērias láticas e leveduras, sendo observado que boa parte da contagem total de microorganismos no caldo aquecido e no caldo pré-evapora do é composto de bãctērias termoresistentes esporulados.

Segundo RODINI (1985), caldos não tratados chegaram a apresentar uma contagem de $1,2 \times 10^{8}$ bactërias/ m]. nas dornas em final de fermentação, sendo identificadas como Leuconostoc. Esse microorganismo somente foi isolado de destilarias que não tratavam o caldo com aquecimento, re presentando 1,5\% das bactérias isoladas e identificadas. 
Ainda, de acordo com a autora, foi constatada nas destilarias que fazem o tratamento térmico do caldo, uma população de bactérias constituỉdas quase que exclusivạ mente por bastonetes Gram + esporulados $(62,1 . \%)$, enquanto bastonetes Gram negativos, não esporulados foram encontrados em menor proporção $(28,8 \%)$.

A diferença da população bacteriana entre as destilarias que tratam o caldo daquelas que não o fazem, co mo esperado, demonstra o efeito seletivo do tratamento térmico, favorecendo as bactérias esporuladas.

Segundo a COPERSUCAR (1983), a caleagem ou sulfitação e caleagem seguidas do tratamento térmico, permí tem uma redução substancial na contagem microbiana. Dessa forma, o mosto preparado com caldos assim tratados apresenta contagem sempre inferior a $5 \times 10^{6}$ microorganismos por mililitro, sendo também pređominante o grupo de bactérias láticas. 


\section{Material e Métodos}

\subsection{Matēria-prima}

A cana-de-açūcar utilizada no presente trabaIho, foi proveniente de áreas experimentais da Fazenda Areão, da Escola Superior de Agricultura "Luiz de Queiroz" - USP. As amostras de cana-de-waçūcar não pertenciam a uma mesma variedade e tampouco houve preocupação quanto à idade, corte, solo e adubação dentro do perïocio utilizado. As canas utilizą das nos experimentos não obedeceram a qualquer critério para o corte, admitindo-se que a amplitude de variação na composição pudesse talvez fornecer dados válidos para todas as situações encontradas na prâtica.

As canas cruas eram processadas imediatamente apōs a colheita, procediendo-se a extração do caldo em prensa hidrāulica Coảistil modelo PH 45 II nas condiçōes padrão de operação: 1 minuto a $250 \mathrm{~kg} / \mathrm{cm}^{2} /$ amostra, após prévia desinte- 
gração em desintegrador de cana.

3.2. Preparo do Mosto

o caldo de cana após extração em prensa hidrāụ lica foi filtrado em algodão para retirada de impurezas grosseiras e submetido a dois tipos de tratamento: aquecimento e defecação simples.

3. 3. Preparo do Inöculo

O inóculo utilizado nos ensaios consistia de uma suspensão de fermento prensado Fleischmann (Saccharomyces cerevisiaé em ăgua destilada, de concentração igual a $25 \mathrm{~g}$ de fermento úmido/l00 ml de ägua destilada correspondendo a cerca de $25 \times 10^{8}$ cêtulas/mi.

Após pesagem de $25 \mathrm{~g}$ do fermento, este era diluído em cerca de $50 \mathrm{ml}$ de água destilada e ajustado à pH 2,5 com solução de $\mathrm{H}_{2} \mathrm{SO}_{4}$ IN atrav́es de potenciōmetro. A suspensão era transferida para balão volumétrico de $100 \mathrm{ml}$ conpletando-se o volume com ägua destilada e homogeneizando-se manualmente.

3.4. Condução do Experimento

Foram realizados 12 ensaios: sendo 6 para clarificação por defecação e 6 para tratamento térmico. Para cada ensaio foi utilizado um caldo dife- 
rente em composição. Cada caldo sofreu 3 tìos de tratamento: (1) testemunha (sem tratamento), (2) aquecimento durante 5 minutos ou defecação a frio e aquecimento por 5 minutos, aquecimento durante 60 minutos ou defecação a frio è aqueci mento por 60 minutos.

As análises químicas foram feitas sempre com 3 repetições.

\subsubsection{Aquecimento}

o caldo filtrado foi separado em 10 frações de $250 \mathrm{ml}$, sendo submetidas a tratamento térmico à temperatura constante em torno de $100^{\circ} \mathrm{C}$ durante 5 e 60 minutos, respectivamente. Uma Eração de $500 \mathrm{ml}$, sem tratamento constituía a testemunha.

O aquecimento foi efetuado em uma cuba de vidro temperado contendo 10 provetas graduadas de $250 \mathrm{ml}$, com um agitador e um aquecedor para manter a temperatura constante em torno de $100^{\circ} \mathrm{C}$. Esse conjunto foi utilizado tanto no ensaio de tratamento térmico quanto no de defecação.

As frações tratadas termicamente. foram resfria das em āgua corrente, e, depois, centrifugadas em centrífuga IEC-$\mathrm{SP}$ refrigerada a $600 \mathrm{~g}$ durante 5 minutos, utilizando - se $500 \mathrm{ml}$ do sobrenadante de cada tratamento para fermentação, e o restante para análises quanto ao teor de açūcares redutores totais, fósforo inorgânico," nitrogênio total, amoniacal, não protéico e contagem microbiana. 


\subsubsection{Defecacão simples \\ o caldo filtrado foi ajustado a $\mathrm{pH} 6,0 \quad \mathrm{com}$} leite de cal a $10^{\circ}$ Bé e transferido para 10 provetas de 250 ml, sendo estas colocadas em banho-maria com agitação e tempe ratura constante em torno de $100^{\circ} \mathrm{C}$, até que atingissem o equilíbrio e permanecessem durante 5 a 60 minutos nessa condição.

Os caldos defecados foram resfriados em ågua corrente e centrifugados, aproveitando-se $500 \mathrm{ml}$ do sobrena dante, de cada tratamento, para fermentação e o restante para anālises.

Uma fração de $500 \mathrm{ml}$, testemunha, não sofrel nenhum processo de purificação, sendo conduzido à fermentação.

Os caldos submetidos aos tratamentos de defecạ ção e aquecimento foram analisados quanto ao teor de açūcares redutores totais, fósforo inorgânico, nitrogênio total, amoniacal, não protéico e contagem microbiana.

\subsection{Métodos Analiticos}

3.5.1. Açūcares redutores totais do caldo foram determinados segundo a técnica de LANE-EYNON (1934).

3.5.2. Açūcares residuais do vinho pela técnica de NIZOVKIN E EMEL'YANOVA (1960). 
3.5.3. Nitrogênio Total: foi determinado pelo método de Micro-Kjeldahl (BAILEY, 1967).

3.5.4. Nitrogênio Amoniacal: a determinação foi feita segundo o método de Micro-Kjeldahl descrito por MEEKER e WAGNER (1933); que consta de destilação no aparelho de microkjeldahl, de $2 \mathrm{ml}$ de amostra, em pH alcalino, acertado com solução de $\mathrm{NaOH} 50 \% \mathrm{p} / \mathrm{v}$ e titulado com solução de $\mathrm{HCl} 0,01 \mathrm{~N}$ em presença do indicador misto de vermelho de metila-azul de metileno.

3.5.5. Nitrogênio Não Protéico: determinado segundo método de Micro-Kjeldahl (BAILEY, 1967), com desproteinização prévia da amostra com partes iguais de hidróxido de bārio 0,3N e sulfato de zinco 5\% (VILELLA, BACILA e TASTALDI, 1973).

3.5.6. Fósforo Inorgānico: determinado pela técnica de GOMORI (1942).

3.5.7. Teor Alcoólico do Vinho: o grau alcoólico do vinho foi obtido por destilação de $50 \mathrm{ml}$ da amostra em microdestilador Tecnal modelo $\mathrm{TE}-012$ recolhendo-se $50 \mathrm{ml}$ do destilado em balão volumétrico e determinando-se a densidade relativa da solução em densímetro digital A.PAAR (DMA-45).

3.5.8. Determinação de pH: determinado em pH-metro digital Methrohm Herisau, modelo E532.

3.5.9. Contagem de Colonias - A determinação do nüme- 
ro total de colonias foi realizada pela técnica convencional de diluição em série e plaqueamento em plate count Agar, composto de bacto-triptona Difco, 5,0 g: extrato de carne oxoid, $2,5 \mathrm{~g}$; bacto-dextrose Difco, $10,0 \mathrm{~g}$; ăgar Difco, 8,0 g; água destilada, q.s.p., $1.000 \mathrm{ml}$.

\subsection{Fermentação Alcoōlica}

Cada suspensão de fermento comercial prensado Fleischmann de concentração $25 \mathrm{~g} / 100 \mathrm{ml}$ foi aciicionada em Erlenmeyer de $1.000 \mathrm{ml}$ contendo o mosto testemunha e as frações de mosto que haviam sido submetidas ao aquecimento e defeca ção durante 5 e 60 minutos.

Cada Erlenmeyer contendo inóculo e mosto foi fermentado por cerca de 24 horas em incubadora tipo General Electric Precision Scientific Modelo 805 à temperatura constante de $32^{\circ} \mathrm{C}$.

Os vinhos obtidos da fermentação dos caldos anteriormente referidos nos itens 2.4.1. e 2.4.2. foram centri fugados para separação da massa celular e o sobrenadante submetidos a uma série de anālises que incluem: análise do teor alcoólico, determinação de pH, determinação de fosfato, determinação de açúcares residuais, determinação do teor de nitrogẹe nio total, amoniacal, não protéico.

A determinação do peso seco de leveduras produ- 
zidas durante o período de fermentação foi efetuada por centrifugação de $10 \mathrm{ml}$ de amostra, lavagem por resuspensão e posterior filtração do microorganismo em membrana Millipore tipo $A A$, com $0,8 \mu \mathrm{m}$ de porosidade, $47 \mathrm{~mm}$ de diâmetro, especifica para leveduras, seguida de secagem em estufa a $105^{\circ} \mathrm{C}$, até peso constante.

\subsection{Delineamento Experimental e Anälise Estatistica}

o delineamento experimental adotado foi de blo cos casualizados.

A análise estatística dos dados referentes ao teor de fósforo inorgânico, nitrogênio total, amoniacal, protéico, não protéico, população microbiana em função da defecą ção e tratamento térmico foram realizados atravês de anäli.se de variância, em blocos casualizados de acordo com o seguinte esquema:

\begin{tabular}{lc}
\hline Causas da variação & G.I. \\
\hline Blocos & 5 \\
Tratamentos & 2 \\
Residuo & 10 \\
\hline Total & 17 \\
\hline
\end{tabular}

Usou-se o teste $\mathrm{F}$ para as análises estatísti cas e as comparações entre as médias dos tratamentos foram efetuados pelo teste de Tukey, segundo GOMES (1982). 
As anälises dos dados foram realizados em micro computador CP 500 da Prológica, em linguagem Basic pertencente ao Departamento de Entomologia da ESALQ. 


\section{Resultados e Discussão}

\subsection{Composição}

Pelas análises quỉmicas realizadas em caldos obtidos por prensagem, verifica-se que a concentração dos componentes do caldo de cana sofreram variações abrup̣tas que podem ser justificadas pela diferença de época em que foram tomadas as amostras, de estágio de maturação, condições climáticas, condições de solo, sistema de cultivo e variedades diferentes (GEERLIGS, 1924; SPENCER e MEADE, 1945; BLISS e MADON, 1946; PAYNE, 1969).

Os teores de nitrogênio total dos caldos tes temunhas conforme pode mser observados nas tabelas 1 e 2 variaram de 21,14 a 99,26 mg/l00 ml, sendo a média de 45,73 mg\% portanto com um valor mínimo abaixo do citado por FORT e MCKAIG (1939), que é de $47 \mathrm{mg} \%$, e em algumas amostras acima dos valores determinados por GEERLIGS(1924), que são de 18 a $62 \mathrm{mg}$. 
Em algumas amostras, constatou-se que o teor de nitrogênio total esteve próximo e acima dos valores encontrados por Brown e Blowin, citados por WIGGINS (1969), GEERIIGS (1924), WIGGINS (1969), Hardin, citado por FARNELL (1924) e SHARMA e JOHARY (1984), que foram $50 \mathrm{mg} \%, 36 \%, 18 \mathrm{mg} \%, 40$ $\mathrm{mg} \%$ e as 20-60 mg\%, respectivamente.

Quanto ao.teor de nitrogênio amoniacal, verifica-se pela tabela 1 que sua concentração no caldo variou de $1,12 \mathrm{mg} / 100 \mathrm{ml}$ a $35 \mathrm{mg} / 100 \mathrm{ml}$.

$$
\text { Browne, citado por SPENCER e MEADE }
$$

(1945), não estabeleceu um valor preciso para o teor de nitrogênio amoniacal, preferindo referir-se como traços o que revela uma baixa concentração encontrada no càldo.

Jā Hardin, citado por FARNELL (1924), determi nou que a concentração de amônia no caldo de cana era de 2,4 mgo, bem abaixo da média observada em nossas amostras que foi de 11,96 mgo, ou cerca de $21,21 \%$ do nitrogênio total. Deve-se ressaltar que alguns caldos apresentaram teores inferiores aos relatados por Hardin.

A concentração de nitrogênio protéico nos caldos utilizados em nosso experimento estiveram no intervalo de $7,07 \mathrm{mg} \%$ a $29,96 \mathrm{mg} \%$ con uma média de $18,15 \mathrm{mg} \%$ portanto, abaixo do valor minimo determinado por FORT e MCKAIG (1939) em caldos de cana de Louisiānia, que foi de 33 mgo. 
Hardin, citado por FARNELL (1924), estipulou que o teor de nitrogênio protéico representado pelas albumi nas, nucleínas e albumosas (proteoses), corresponde a 8,5 mg . O nitrogênio protéico, em média, representou cerca de 48,02\% do nitrogênio total.

A variação nos teores de proteína encontrados pode ser justificada pela distribuição do material nitrogenado no colmo da cana, que em relação às substâncias albuminóides estão concentradas nos nós da cana (GEERIIGS, 1924).

Os teores de nitrogênio não protéico variaram de $3,08 \mathrm{mg}$ a $44,38 \mathrm{mg} \%$ com uma média de 15,62. mg\%, correspondendo a 30,76 \& do nitrogênio total. Deve ser evidenciado que esses teores não incluem o nitrogênio amoniacal, portanto, a mẹ dia se encontra abaixo do teor mínimo estipulado por FORT e McKAIG (1939), porém, somando-se a média do nitrogênio amoniacal, a concentração média de nitrogênio não protēico ê de $27,58 \mathrm{mg}$ o que está nos limites determinados por FORT e MCKAIG (1939) que são de 21 mg응 a 280 mgㅇ․ .

O método de extração, o estágio de crescimento da planta, a variedade e a distribuição do nitrogênio não protéico no colmo, que é maior no ápice, concorrem para tais diferenças (GEERLIGS, 1924; WIGGINS e WILLIAMS, 1951 e WILSON, 1956). 
As anālises quanto à concentráção de $\mathrm{P}_{2} \mathrm{O}_{5}$ nos caldos testemunha estiveram na faixa de 151,75 a 482,50 ppm, com uma média de 301,63 ppm.

SHARMA et alii. (1981), encontraram variações de 280 a 600 ppm no teor de fosfato inorgânico, de acordo com a idade e fertilização do solo; sendo seu teor maior em regiões de crescimento ativo. Com relação ao teor de fosfatos totais esses variaram de 440 a 850 ppm.

STUPIELLO e HORII (1981), estabeleceram uma faixa de 125 a 150 ppm para que haja uma fermentação alcoólica com bom rendimento.

BENNETT e RAGNAUTH. (1960), HONIG (1960), GUPTA et alii (1965), JANAKIRAMAIAH et alii (1967), PAYNE (1969), DELGADO et alii (1973a) e SILVA Jr. (1976) determinaram que o caldo de cana deve conter de 300 a 350 ppm de $\mathrm{P}_{2} \mathrm{C}_{5} /$ litro pá ra que ocorra uma clarificação eficiente:

Segundo SHARMA e GUPTA (1970), a distribuição de fosfato em vārias porções de cana indica que com o avanço da idade, o teor de fosfatos mostra uma tendência a aumentar ao máximo, seguido por um declínio após período de maturação. O teor de fosfato durante a maturação tem variado de 269 ppm a $312 \mathrm{ppm}$ o que vem a corroborar com o valor médio de 301,63 ppm observado nos caldos testemunha. 
PAYNE et alii (1928), tambëm constataram que os caldos crus variavam consideravelmente na composição, particu larmente quanto ao teor de fosfato.

Tabela 1 - Teor de nitrogenio total, amoniacal, não protëico* e protëico contido nos caldos testemunhas

\begin{tabular}{ccccccc}
\hline $\begin{array}{c}\text { Nitrogênio } \\
\text { Total } \\
\text { mg\% }\end{array}$ & $\begin{array}{c}\text { Nitrogênio Amoniacal } \\
\text { mg\% }\end{array}$ & \multicolumn{2}{c}{$\begin{array}{c}\text { Nitrogénio } \\
\text { não protéico }\end{array}$} & \multicolumn{2}{c}{ Nitrogênio Protéico } \\
\hline 22,19 & 3,36 & 15,14 & 5,88 & 26,50 & 12,95 & 58,36 \\
11,83 & 1,12 & 9,47 & 3,64 & 30,77 & 7,07 & 59,76 \\
14,14 & 1,40 & 9,90 & 3,08 & 21,78 & 9,66 & 68,32 \\
80,92 & 23,66 & 29,24 & 27,30 & 33,73 & 29,96 & 37,02 \\
32,00 & 5,67 & 17,72 & 10,43 & 32,59 & 15,90 & 49,69 \\
38,78 & 7,98 & 20,58 & 10,92 & 28,16 & 19,88 & 51,26 \\
27,86 & 5,46 & 19,60 & 7,56 & 27,13 & 14,84 & 53,26 \\
40,46 & 8,26 & 20,42 & 8,26 & 20,41 & 23,94 & 59,17 \\
98,14 & 35,00 & 35,66 & 37,52 & 38,23 & 25,62 & 26,10 \\
99,26 & 32,90 & 33,15 & 44,38 & 44,71 & 21,98 & 22,14 \\
50,54 & 12,56 & 24,85 & 20,34 & 40,24 & 17,64 & 34,90 \\
32,62 & 6,16 & 18,88 & 8,12 & 24,89 & 18,34 & 56,22 \\
\hline 45,73 & 11,96 & 21,21 & 15,62 & 30,76 & 18,15 & 48,02 \\
\hline
\end{tabular}

Média de 3 repetições

* Sem nitrogênio amoniacal 
Tabela 2 - Composição dos caldos de cana en relação aos teores de nitrogênio, fosfato inorgânico e açücar total

\begin{tabular}{|c|c|c|}
\hline \multirow{2}{*}{$\begin{array}{l}\text { Nitrogênio Total } \\
\text { mg/100 ml }\end{array}$} & \multirow{2}{*}{${ }_{\text {ppm }}^{\mathrm{P}_{2} \mathrm{O}_{5}}$} & ART \\
\hline & & $\mathrm{g} / 100 \mathrm{~g}$ \\
\hline $22,1.9$ & 189,92 & 19,64 \\
\hline 11,83 & 254,54 & 15,47 \\
\hline 14,14 & $15], 75$ & 16,48 \\
\hline 80,92 & 204,81 & 15,74 \\
\hline 32,00 & 482,50 & 15,72 \\
\hline 38,78 & 410,18 & 15,13 \\
\hline 27,86 & 249,19 & 20,09 \\
\hline 40,46 & 449,68 & 19,60 \\
\hline 98,14 & 320,13 & 19,80 \\
\hline 99,26 & 204,81 & 16,40 \\
\hline 50,54 & 232,48 & 14,18 \\
\hline 32,62 & 469,58 & 13,29 \\
\hline 45,73 & 301,63 & 16,79 \\
\hline
\end{tabular}

\subsection{Tratamento Térmico}

Os resultados apresentados a seguir referem-se unicamente aos tratamentos que receberam tratamento térmico, sèm caleagem, pois estes serão trataios posteriormente, no item 4.3, sob a denominação de defecação simples. 
4.2.1. Niirogênio

A influência do tratamento térmico sobre a composição do caldo, no que se refere à concentração de nitrogênio nas formas determinadas como: nitrogênio total, amoniacal, não protéico e protéico está apresentada na tabela 3 .

E bem conhecido que os colóides do caldo de cana são coagulados pelo calor, sofrendo importantes alterações químicas e entre moléculas irreversíveis (DEERR, 1916). A floculação de albumina e substâncias similares pode ser causada por um efeito de pH próximo ao ponto isoelétrico das proteínas, acelerado e aumentado pelo efeito do calor, sendo a coagulação também um resultado da desidratação das proteínas (SCOTT, 1927 e KING, 1931). Não só a temperatura, mas tam bém a concentração iônica, são fatores importantes na remoção de proteínas e segundo BLISS e MADON (1946) as albuminas coagulam melhor a valores de $\mathrm{pH}$ próximos aos encontrados para caldo de cana e a temperatura de $80^{\circ} \mathrm{C}$.

Observando-se a tabela 3 , verifica-se que os valores de nitrogênio total reduzem-se após tratamentos de 5 e 60 minutos a $100^{\circ} \mathrm{C}$ e posterior centrifugação.

A anālise estatística dos resultados apresentados no quadro 1, pela aplicação do Teste F, para nitrogê nio total no caldo, mostrou significância ao nível de lo 


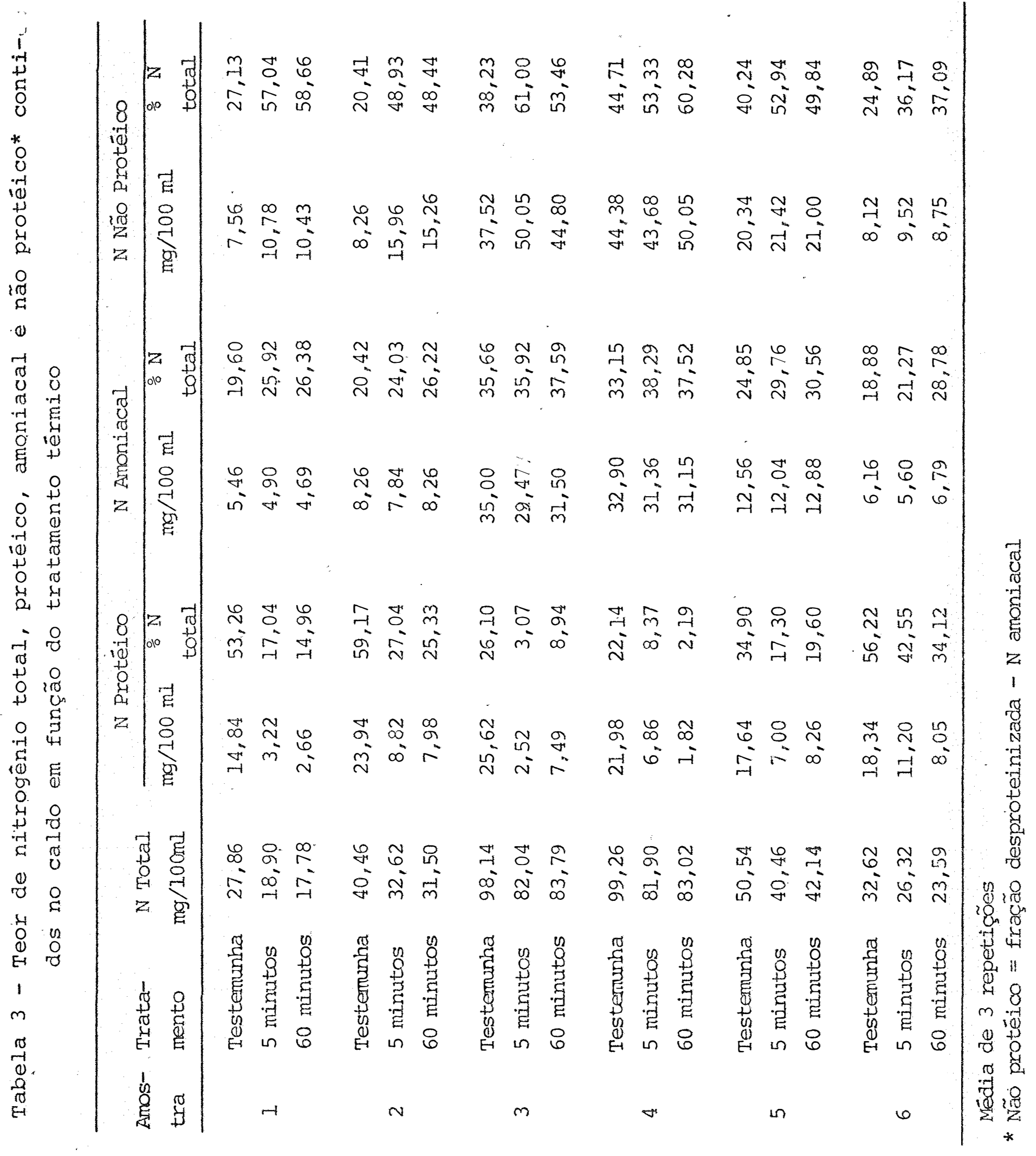


de probabilidade rara os tratamentos e a aplicação do Teste de Tukey mostrou que a maior mëdia, correspondente à testemu nha, difere significativamente, ao nivel de 5\% de probabilidade, das médias dos tratamentos 5 minutos e 60 minutos e que estas näo diferem entre sí.

Quadro 1 - Efeito do tratamento tërnico do caldo no teor de nitrogênio total

\begin{tabular}{lccccc}
\hline Causa da variação & G.L. & S.Q. & Q.M. & F & Nível \\
\hline Blocos & 5 & 63,227800 & 12.645600 & $1147,84 * *$ & 0,00 \\
Tratamentos & 2 & 2,509280 & 1,254640 & $113,88^{* *}$ & 0,00 \\
Residuo & 10 & 0,110168 & 0,011017 & & \\
\hline Total & 17 & 65,847200 & & & \\
\hline
\end{tabular}

Dados transformados para $\sqrt{\mathrm{x}+0,5}$

** Ao nivel de $1 \%$ ao menos um contraste de mëdias difere de zero

coeficiente de variação $=1,52196 \%$

Teste de Tukey 5\% para tratamentos

$\mathrm{DMS}=0,166259$

Tratamento $1=7,42407 \mathrm{~A}$

Tratamento $2=6,65016 \mathrm{~B}$

Tratamento $3=6,61506 \mathrm{~B}$

Observa-se pela tabela 4 que a remoção média de nitrogênio total após os tratamentos 5 e 60 minutos de aquecí mento foi de $20,78 \%$ e $22,26 \%$, respectivamente, embora, possive 1 mente em função da variação do teor de proteínas nas diversas amostras, a percentagem de eliminação do nitrogênio total te- 
nha variado de 14,62 a 36,180 em relação às testemunhas.

Segundo SATYANARAXANA (1952), a quantidade de nitrogênio removido por ebulição e diversos métodos de clari ficação sob diferentes condições, tem sido relativamente constante, da ordem de $30 \%$ do nitrogênio total presente na cana. Os resultados presentemente obtidos, vêm, de certo modo, corroborar com os dados constantes na literatura.

Tabela 4 - Remoção do nitrogênio total durante o tratamento térmico do caldo

\begin{tabular}{ccc}
\hline Amostra $^{*}$ & $\begin{array}{c}\text { Aquecimento } 5 \text { min. } \\
1\end{array}$ & $\begin{array}{c}\text { Aquecimento } \\
1\end{array}$ \\
2 & 32,16 & 36,18 \\
3 & 19,37 & 22,14 \\
4 & 16,40 & 14,62 \\
5 & 17,49 & 16,36 \\
6 & 19,94 & 16,62 \\
\hline Média & 19,31 & 27,68 \\
\hline
\end{tabular}

* Cada amostra é apresentada como média de 3 repetições.

Em relação ao nitrogênio protéico (Tabela 3), observa-se que a fração protéica representa de 22,14 à 59,17\% do nitrogênio total do caldo, em mëdia, 4l,96\%, e que em função dos tratamentos térmicos, sofremi uma considerävel redução decorrente da precipitação e, em parte, pela transformação em fração não protēica. Os teores de nitrogênio protéi 
co nos caldos tratados, representaram de 2,19 a 42,558 , em mê dia, 18,37 응

A análise estatística detectou que os caldos tratados diferem, significativamente, ao nível de lo de probabilidade, da testemunha e que as médias dos tratamentos 2 e 3, respectivamente, 5 e 60 minutos de aquecimento, não apresentaram diferenças entre si (Quadro 2).

Quadro 2 - Efeito do tratamento térmico do caldo no teor de nitrogênio protéico

\begin{tabular}{lccccc}
\hline Causa da variação & G.L. & S.Q. & Q.M. & F & Nível \\
\hline Blocos & 5 & 1,854870 & 0,370975 & $1,23 \mathrm{~ns}$ & 36,27 \\
Tratamentos & 2 & 17,497700 & 8,748850 & $29,07 * *$ & 0,01 \\
Resĩduo & 10 & 3,009220 & 0,300922 & & \\
\hline Total & 17 & 22,361800 & & \\
\hline
\end{tabular}

Dados transformados para $\sqrt{x+0,5}$

** - Ao nível de 1\% ao menos un contraste de médias difere de zero Coeficiente de variação $=16,9345 \%$

Teste de Tukey 5\% para tratamentos

DMS $=0,868926$

Tratamento $I=4,63219 \mathrm{~A}$

Tratamento $2=2,59858 \mathrm{~B}$

Tratamento $3=2,48721 \mathrm{~B}$ 
Observa-se na Tabela 5 que o percentual de remoção de nitrogênio protéico é bastante variável dentro de cada tratamento ( 5 e 60 minutos de aquecimento), de 38,93 a $90,53 \%$, com média de $66,67 \%$ e de 53,17 a 91,72\%, com média de 70,08\%, respectivamente. A larga variação pode ser decorrente das formas protéicas presentes, ou, ainda, porque parte das proteínas podem ter sido convertidas em peptídeos, pepto nas e aminoácidos, solúveis e não elimináveis por precipitaçã்o e que, dessa forma, manifestam-se por um aumento no teor de nitrogênio não protëico, sendo as proteinas coaguláveis pelo calor removidas durante a operação, de acordo com SATYNARAyana (1952), PAVLAS e HAUSLEROVA (1956); VEGA (1957) e PEREZ et alii (1978). Ainda, segundo FARNELL (1924), o método de determinação de proteína não é suficientemente específico para excluir constituintes orgânicos nitrogenados do caldo. O autor estimou que a proteina calculada como $6,3 \times \mathrm{N}$, constituía $0,73 \%$ do Brix do caldo da cana e que somente $29,4 \%$ desse valor era matéria não dializável, portanto, de verda deira natureza protéica.

Para MARTIN (1969), a proteína existente no colmo e em folhas em desenvolvimento não é uma substância cristạ lizável definitivamente caracterizada, senão que mais repre senta uma proteína em vários estágios de agregação ou síntese. Ela não é molecularmente homógênea e, com toda probabilidade, dissolve-se ou dispersa-se facilmente no caldo, na forma de colóide. Está, indubitavelmente, acompanhada por moléculas 
de peptideos de baixo peso molecular, os polipeptideos, que tenham propriedades intermediärias entre as proteinas e os aminoäcidos livres.

Tabela 5 - Remoção de nitrogênio protéico durante o tratamen to térmico do caldo

\begin{tabular}{ccc}
\hline Amostra* & $\begin{array}{c}\text { Aquecimento } \\
\frac{0}{0}\end{array}$ & $\begin{array}{c}\text { Aquecimento } 60 \mathrm{~min} . \\
\text { ( }\end{array}$ \\
\hline 2 & 78,30 & 82,07 \\
3 & 63,16 & 66,66 \\
4 & 90,53 & 70,76 \\
5 & 68,79 & 91,72 \\
6 & 60,31 & 53,17 \\
\hline Média & 38,93 & 56,10 \\
\hline
\end{tabular}

* Cada amostra é apresentada como média de 3 repetições.

Em relação ao teor de nitrogênio amoniacal, observa-se à Tabela 3 que o mesmo representa uma fração variável de 18,88 a $35,66 \%$, em média, 25,43\%, do nitrogênio total.

A análise estatística apresentada no Quadro 3, não detectou diferenças entre os tratamentos, apresentando um valor de $F$ não significativo para tratamentos.

Embora a metodologia utilizada para sua determinação possa apresentar uma variação decorrente do próprio mētodo, è possível verificar-se que a fração amoniacal é con 
siderävel e não traços como encontrado por Browne, citado por SPENCER E MEADE (1945), e aproximada aos valores de nitrogênio não orgânico observado por Hardin, citado por FARNELL (1.924).

A variação encontrada nos teores de nitrogê nio amoniacal após os tratamentos térmicos é pequena e a diferença è não significativa pela anälise estatística, como jả foi visto, de modo que pelos valores encontrados (Tabela 3), pode-se afirmar que seu teor é praticamente constante. obviamente, sendo seu teor inalterado no caldo tratado e havendo xemoção de nitrogènio protéico, a sua concentração relativa em função do nitrogênio total em cada amostra esta rá aumentada. A média de nitrogênio amoniacal nos caldos tratados foi de $30,19 \%$, ou seja, 4,76\%, em mẻdia, maior que nos caldos sem tratamento.

Quadro 3 - Efeito do tratamento térmico do caldo no teor de nitrogênjo amoniacal

\begin{tabular}{lccccc}
\hline Causa da variação & G.L. & S.Q. & Q.M. & F & Nível \\
\hline Blocos & 5 & 34,550500 & 6,910100 & $676,92 * *$ & 0,00 \\
Tratamentos & 2 & 0,082306 & 0,041153 & 4,03 ns & 5,20 \\
Residuo & 10 & 0,102081 & 0,010208 & & \\
\hline Total & 17 & 34,734900 & & & \\
\hline
\end{tabular}

Dados transfomados para $\sqrt{\mathrm{x}+0,5}$

Coeficiente de variação $=2,65288 \%$

Teste de Tukey 5\% para tratamentos

$\mathrm{DMS}=0,16004$

Tratamento $I=3,88884 \mathrm{~A}$

Tratamento $2=3,81307 \mathrm{AB}$

Tratamento $3=3,72361$ B 
Observando-se o comportamento da fxação não protëica, verifica-se à Tabela 3 que ao inverso do que ocorre ra com nitrogênio total e nitrogênio protéico, seu teor aumentou nas amostras tratadas termicamente, em relação à testemunha. As razões do aumento jä foram discutidas anterior mente.

Do ponto de vista de aproveitamento do caldo para fermentação, tal aumento pode ter um significado importante em termos de maior disponibilidade de nutrientes nitro genados, facilmente assimilāveis pelos microorganismos.

A anālise estatística detectou que a testemu nha difere dos demais tratamentos ao nível de 5\% de probabilidade e que as médias dos caldos tratados năo diferem entre si, confirmando as assertivas anteriores (Quaōro 4).

Quadro 4 - Efeito do tratamento térmico do caldo no teor de nitrogênio não protéico

\begin{tabular}{lccccc}
\hline Causa da variação & G.L. & S.Q. & Q.M. & F & Nível \\
\hline Blocos & 5 & 43,553300 & 8,710660 & $127,98 * *$ & 0,00 \\
Tratamentos & 2 & 0,840057 & 0,420029 & $6,17 *$ & 1,80 \\
Residuo & 10 & 0,680634 & 0,068063 & & \\
\hline
\end{tabular}

Dados transformados para $\sqrt{\mathrm{x}+0,5}$

* Ao nivel de 5\% ao menos um com raste de médias difere de zero Coeficiente de variação $=5,591$

Teste Tukey 5\% para tratamentos $\mathrm{DMS}=0,41325$

Tratamento $2=4,83661 \mathrm{~A}$ Tratamento $3=4,79909 \mathrm{~A}$ Tratamento $I=4,36085 \mathrm{~B}$ 


\subsubsection{Fos $60 \pi 0$}

Os resultados dos tratamentos térmicos a $100^{\circ} \mathrm{C}$ por 5 e 60 minutos em relação ao teor de fosfatos inorgâni cos expressos como $\mathrm{P}_{2} \mathrm{O}_{5}$, estão apresentados na Tabela 6 .

Observa-se que a variação do teor de fösforo é pequena, da ordem de 3 a 10\% inferior à testemunha, em fun ção dos tratamentos, provavelmente porque ao pH natural do caldo, de 5,0 a 5,5, sem qualquer adição de cal, o cálcio existente no mesmo, seja suficiente apenas para reação com $\mathrm{HPO}_{4}^{--}$na proporção da remoção ocorrida.

A anālise estatística dos dados, entretanto, detecta diferenças entre as médias dos diferentes tratamen tos, como se pode verificar no Quadro 5, indicando que a testemunha difere dos demais tratamentos ao nivel de 1\% de probabilidade, e que os tratamentos entre si não diferem estatisticamente. 
Tabela 6 - Teor de fosfato inorgânico contido no caldo em função do tratamento térmico

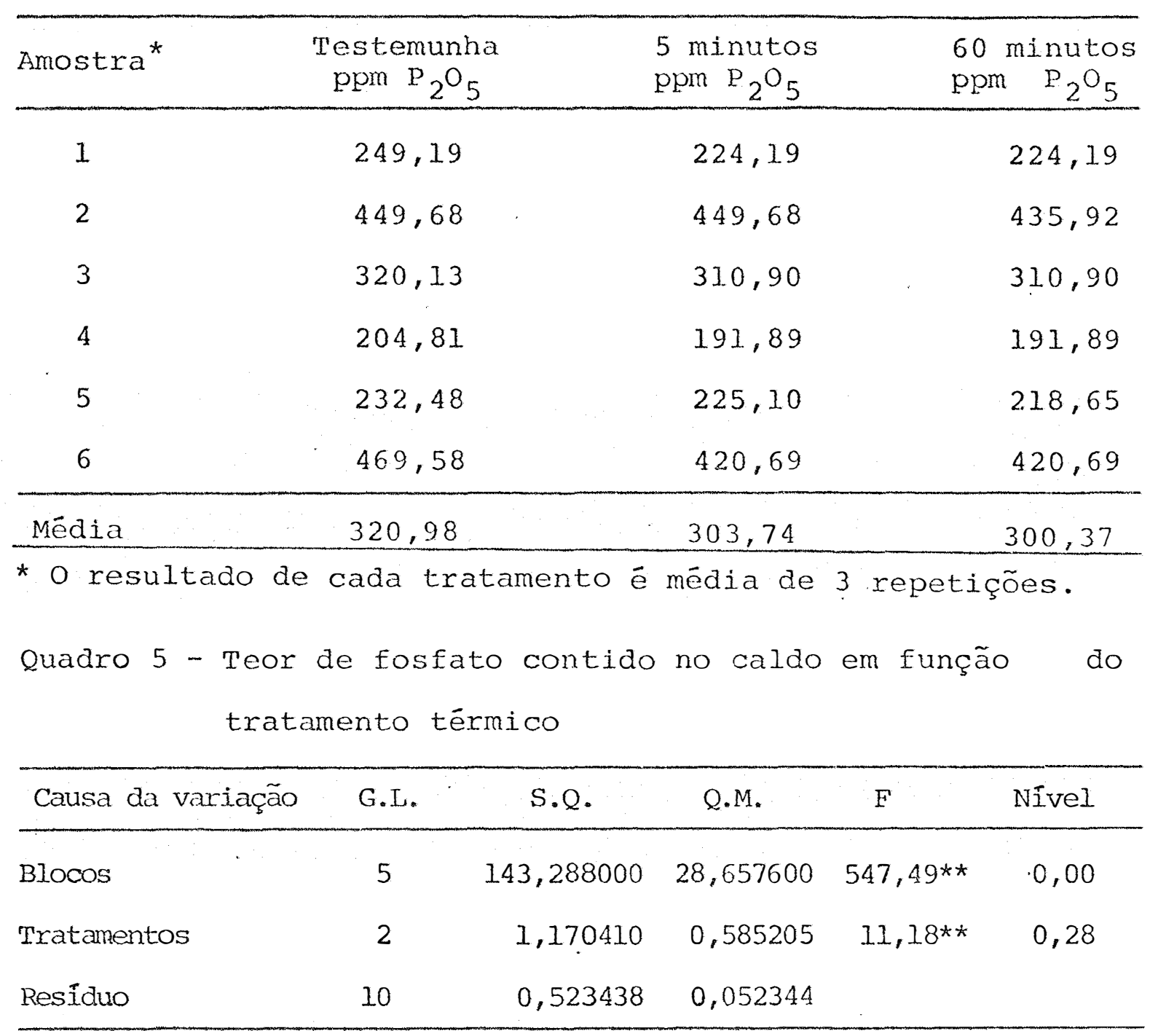

Dados transformados para $\sqrt{x+0,5}$

** - Ao nível de 1\% ao menos um contraste de médias difere de zero coeficiente de variação $=1,31913 \%$

Teste de Tukey 5\% para tratamentos

DMS $=0,3624$

Tratamento $I=17,69980 \mathrm{~A}$

Tratamento $2=17,21120 \mathrm{~B}$

Tratamento $3=17,12070 \mathrm{~B}$ 


\subsubsection{Contagem de Microorganismos}

As amostras de cana-de-açūcar utilizadas nos ensaios foram sempre colhidas momentos antes da extração do caldo, sendo tais canas, não queimadas e não armazenadas, dî ferindo, portanto, substancialmente de canas industriais. Assim, os microorganismos encontrados nos caldos limitaram - se provavelmente só àqueles constituintes da microflora da própria planta e as variações encontradas, sejam em função da sanidade das plantas amostradas, das condições climáticas e da época em que foram colhidas.

Os ensaios de contagem microbiana dos caldos foram realizados separadamente dos demais parâmetros estu ảados, ou seja, as amostras aqui enumeradas de 1 a 7 na Tabela 7 não correspondem às amostras analisadas para nitrogênio e fosfato descritas nos itens 4.2 .1 e 4.2.2.

Os dados obtidos na contagem microbiana. dos caldos com e sem tratamento estão mostrados na Tabela 7 . Tabela 7 - População microbiana do caldo de cana

\begin{tabular}{cccc}
\hline Amostra & \multicolumn{3}{c}{ Tempo de Aquecimento a $100^{\circ} \mathrm{C}$} \\
\hline 1 & 0 & $0,0003 \times 10^{5}$ & 60 minutos \\
2 & $2,4 \times 10^{5}$ & $0,0065 \times 10^{5}$ & $0,0003 \times 10^{5}$ \\
3 & $2,1 \times 10^{5}$ & $0,0019 \times 10^{5}$ & $0,0025 \times 10^{5}$ \\
4 & $17,5 \times 10^{5}$ & $0,0090 \times 10^{5}$ & $0,0035 \times 10^{5}$ \\
5 & $82 \times 10^{5}$ & $0,513 \times 10^{5}$ & $0,0003 \times 10^{5}$ \\
6 & $387 \times 10^{5}$ & $0,356 \times 10^{5}$ & $0,0696 \times 10^{5}$ \\
7 & $540 \times 10^{5}$ & $0,0189 \times 10^{5}$ & $0,005 \times 10^{5}$ \\
\hline
\end{tabular}


Os resultados da contagem microbiana foram submetidos à análise estatística (Quadro 6) - Teste F e de Tukey, ficando evidenciado que as médias relativas aos trata mentos 5 e 60 minutos de aquecimento não diferiram entre si estatisticamente, embora diferissem significativamente, ao nível de 5요 de probabilidade, da testemunha sem tratamento. O coeficiente de variação, extremamente elevado, certamente é decorrente da variação muito alta entre as populações existentes em cada amostra, que, em sî, não são repetições, mas sim repetições de experimentos. O desdobramento da análise estatística, amostra a amostra, apresentada no Apēndice deste trabalho (Quadros 17 a 23), mostra que dentro de cada experimento o coeficiente de variação é aceitável e reflete a precisão na condução dos ensaios.

Pode-se observar que caldos tratados termicamente a $100^{\circ} \mathrm{C}$ por 5 minutos, em condições de laboratório, tem sua população reduzida a níveis praticamente desprezíveis, da ordem de 0,01.\%, talvez em razão de que o aquecimento até atingir os $100^{\circ} \mathrm{C}$ seja muito mais lento do que os observados em processos industriais, além do próprio tempo necessārio para resfriamento das amostras, em āgua corrente.

O tratamento por 5 minutos resultou em redução tão drástica, obviamente um tratamento mais prolongado, por 60 minutos contribuiu, em geral, para reduzir ainda mais a população, levando quase à esterilidade. Possivelmente, as 
bactērias remanescentes, sejam organismos como os Actinomyce tos termofilicos muito semelhantes ao I.euconostoc ou, ainda, B. megatherium, encontrados no processamento após aquecimento e caleagem, como citado por BEVAN e BOND (1971) e bactérias esporuladas que resistiram ao tratamento (RODINI, 1985).

Neste caso, a contagem microbiana de caldos tratados industrialmente, sempre elevada, seria decorrente de baixo tempo de residência, falhas de equipamento ou a tese de recontaminação como defendida por LUCREDI et alii (1984).

Quadro 6 - Efeito do tratamento térmico do caldo na popula ção microbiana

\begin{tabular}{lccccc}
\hline Causa da variação & G.L. & S.Q. & Q.M. & F & Nível \\
\hline Blocos & 6 & 153,798000 & 25,632900 & $1,04 \mathrm{~ns}$ & 44,45 \\
Tratamentos & 2 & $345,91.0000$ & 172,955000 & $7,05^{* *}$ & 0,95 \\
Residuo & 12 & 294,536000 & 24,544700 & \\
\hline Total & 20 & 794,244000 & & & \\
\hline
\end{tabular}

Dados transformados para $\sqrt{x+0,5}$

** - Ao nível de $1 \%$ ao menos um contraste de médias difere de zero Coeficiente de variação $=136,87 \%$

Teste Tukey 5\% para tratamentos

DMS $=7,05945$

Tratamento $I=9,35922 \mathrm{~A}$

Tratamento $2=0,78470 \mathrm{~B}$

Tratamento $3=0,71513 \mathrm{~B}$ 


\subsection{Defecação Simples}

Os resultados apresentados e discutidos a seguir, referem-se aos tratamentos que sofreram caleagem a frio, até $\mathrm{pH}$ 6,0, e posterior aquecimento, em banho, até $100^{\circ} \mathrm{C}$, onde permaneceram a temperatura constante por 5 e 60 minutos. Os' caldos tratados foram resfriados, centrifugados e analisados.

4.3.1. Nitrogênio

Os resultados da defecação a $\mathrm{pH} 6,0$ sobre a fração nitrogenada do caldo, determinada e analisada como nitrogênio total, amoniacal, não protéico e protéico, estão apresentados na Tabela 8 .

Em relação ao nitrogênio total, observa-se que a defecação simples, a frio e a pH 6,0, com subsequente aquecimento a $100^{\circ} \mathrm{C}$ por 5 e 60 minutos, contribui para a redução do nitrogênio total do caldo de forma muito semelhante àquela encontrada para os tratamentos térmicos, somente.

A análise estatística dos resultados apresentados no Quadro 7, mostram que os tratamentos diferem significativamente ao nível de 1 \% de probabilidade e a aplicação do teste de Tukey evidencia que a maior média, correspondente ao tratamento testemunha, difere significativamente, ao nível de 5: ce probabilidade, dos tratamentos com defecação 


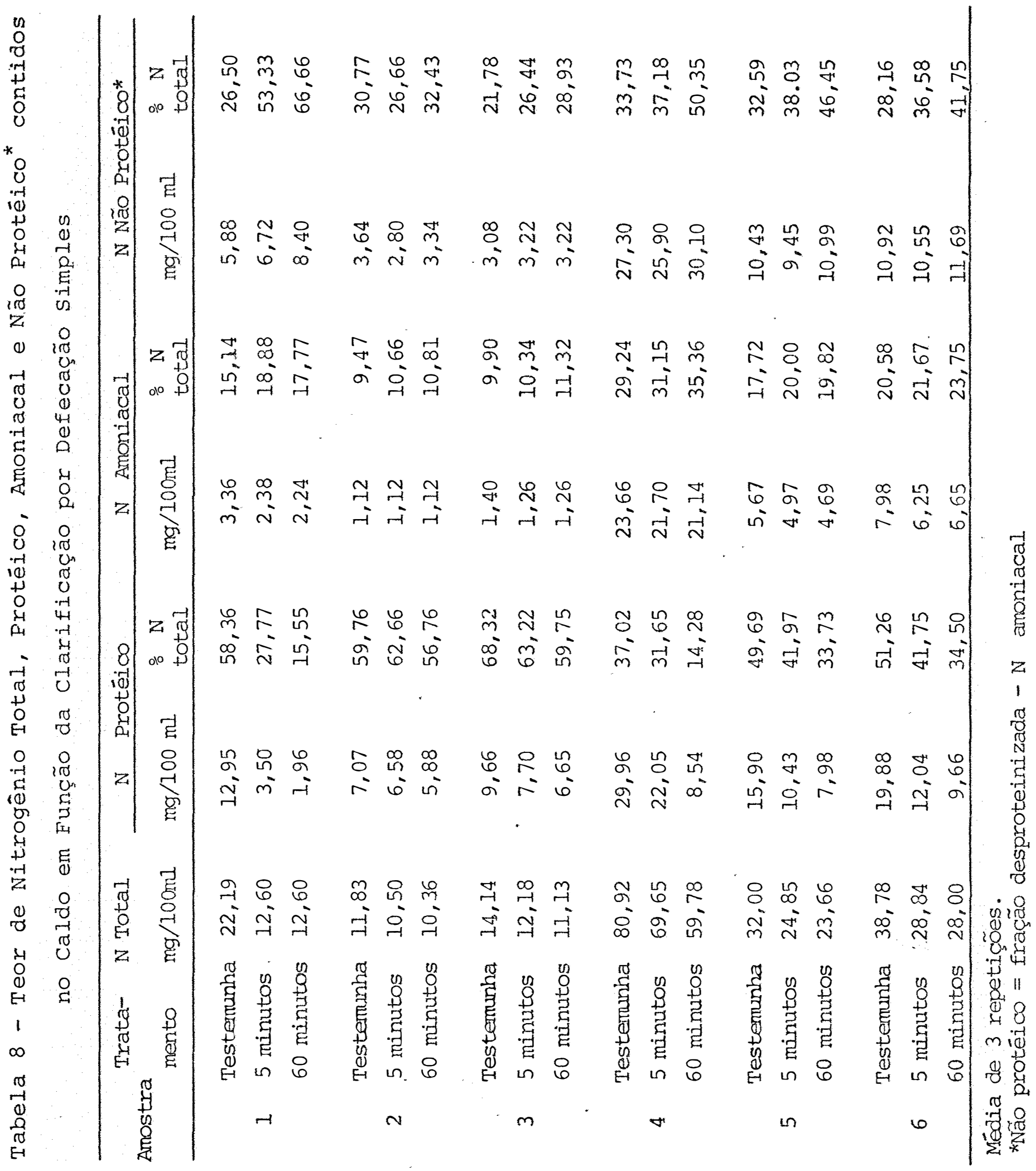


simples ( 5 e 60 minutos a $100^{\circ} \mathrm{C}$ ), os quais não diferem estatisticamente entre si. A análise estatística vem demonstrar a veracidade das conclusões, entretanto, observando-se as médias de remoção apresentadas na Tabela 9, verifica-se que a redução de nitrogênio total corresponde a 21,70 e 26,14\% e que tais resultados são absolutamente similares aos obtidos no tratamento térmico. Para FARNELL (1924), as condições isoelétricas do caldo podem estar mais próximas do pH do caldo in natura do que do caldo caleado, de modo que a expectativa de maior precipitação de corpos nitrogenados deve ocorrer a caldos apenas aquecidos do que em caldos aquecidos após adição de cal.

Os resultados obtidos, embora não difiram dos tratamentos térmicos, são próximos aos encontrados por SATYANARAYANA (1952), qrue revelam valores de remoção da ordem de 30\% para caldos clarificados; GUAZON (1935), que obteve remoções de 10 a 32\% com média de 15,6\%; PAYNE (1969), que afirma que o nitrogênio removido na clarificação pode variar de 12,5 a $60 \%$ sendo a média geral um terço desse valor; LAPIN et alii (1978), que verificaram serem os percentuais de remoção no esquema clássico, 26-27\%; ZAKKHAROV et alii (1983) que encontraram um máximo de remoção de $36,8 \%$. 
Quadro 7 - Efeito da defecação simples do caldo no teor de nitrogênio total

\begin{tabular}{lccccc}
\hline Causa da variação & G.L. & S.Q. & Q.M. & F & Nível \\
\hline Blocos & 5 & 52,710500 & 10,542100 & $182,93^{* *}$ & 0,00 \\
Tratamentos & 2 & 2,095610 & 1,047810 & $18,18^{* *}$ & 0,05 \\
Resíduo & 10 & 0,576294 & 0,057629 & & \\
\hline Total & 17 & 55,382400 & & & \\
\hline
\end{tabular}

Dados transformados para $\sqrt{\mathrm{x}+0,5}$

** - Ao nível de 1\% ao menos um contraste de médias difere de zero

Coeficiente de variação $=4,76104 \%$

Teste de Tukey 5\% para tratamentos

DMS $=0,380258$

Tratamento $I=5,51543 \mathrm{~A}$

Tratamento $2=4,88733 \mathrm{~B}$

Tratamento $3=4,72383 \mathrm{~B}$

Tabela 9 - Remoção de nitrogênio total do caldo, durante processo de defecação simples

\begin{tabular}{ccc}
\hline Amostra* & $\begin{array}{c}\text { Aquecimento } \\
\frac{0}{0}\end{array}$ & $\begin{array}{c}\text { Aquecimento } \\
\%\end{array}$ \\
\hline 1 & 43,21 & 43,21 \\
2 & 11,24 & 12,42 \\
3 & 13,86 & 21,28 \\
4 & 13,93 & 26,12 \\
5 & 22,34 & 26,06 \\
6 & 25,63 & 27,79 \\
\hline Média & 21,70 & 26,14
\end{tabular}

* Cada amostra é apresentada corno inédia de 3 repetições. 
Observando-se a Tabela 8 , no que se refere aos teores de nitrogênio protëico, observa-se que ocorreu uma redução crescente com o tempo de aquecimento, o que em termos de participação percentual do nitrogênio protéico em relação ao nitrogênio total, se reflete também como um decréscimo.

Estatisticamente, os tratamentos diferem entre sí ao nível de 1\% de probabilidade. O teste de Tukey detecta que a maior média corresponde à testemunha e difere dos trata mentos 2 e 3 (5 e 60 minutos) e estes, por sua vez, diferem entre si, segundo se pode verificar no Quadro 8.

Comparando-se aos resultados obtidos no tratamento térmico, observa-se à Tabela 10 que a remoção de nitrogênio protéico através da defecação simples, foi de 33,40 e $50,92 \%$, respectivamente, para os tratamentos (2) e (3) e que estes valores são inferiores aos observados no experimento an terior. Erovável que a elevação do pH tenha reduzido reações hidrolíticas e a eliminação corresponda mais ao teor de proteínas coaguladas e precipitadas, adsorvidas ao cálcio adi cionado. Observa-se que os teores de substâncias nitrogenadas determinadas como nitrogênio amoniacal e não protéico apresentam uma variação muito pequena, variando apenas em termos de concentração relativa, ou seja, quando comparados aos teores de nitrogênio total.

A análise dos dados de nitrogênio não protéico está mostrada no Quadro 9. 
Quadro 8 - Efeito da defecação simples do caldo no teor de nitrogênio protéjco

\begin{tabular}{lccccc}
\hline Causa da variação & G.I. & S.Q. & Q.M. & F & Nível \\
\hline Blocos & 5 & 8,522490 & 1,704500 & $7,09 * *$ & 0,45 \\
Tratamentos & 2 & 5,138060 & 2,569030 & $10,68 * *$ & 0,33 \\
Resíduo & 10 & 2,405260 & 0,240526 & & \\
\hline Total & 17 & 16,065800 & & & \\
\hline
\end{tabular}

Dados transfonmados para $\sqrt{x+0,5}$

** - Ao nivel de 1\% ao menos um contraste de médias difere de zero

Coeficiente de variação $=15,0429 \%$

Teste Tukey 5\% para tratamentos

DMS $=0,77685$

Tratamento $1=3,94824 \mathrm{~A}$

Tratamento $2=3,18672 \mathrm{AB}$

Tratamento $3=2,64574 \quad B$

Tabela 10 - Remoção de nitrogênio protéico do caldo, durante - processo de defecação simples

\begin{tabular}{ccc}
\hline Amostra* & $\begin{array}{c}\text { Aquecimento } 5 \text { minutos } \\
\text { oquecimento } 60 \text { minutos }\end{array}$ & $\begin{array}{c}\text { Aqu } \\
1\end{array}$ \\
\hline 2 & 72,99 & 84,86 \\
3 & 6,93 & 16,83 \\
4 & 20,29 & 31,16 \\
5 & 26,40 & 71,49 \\
6 & 34,40 & 49,81 \\
\hline Média & 39,43 & 51,40 \\
\hline * Cada amostra é apresentada como média de 3 repetições.
\end{tabular}


Quadro 9 - Efeito da defecação simples do caldo no teor de nitrogênio não protēico

\begin{tabular}{lccccc}
\hline Causa da variação & G.L. & S.Q. & Q.M. & F & Nível \\
\hline Blocos & 5 & 23,729000 & 4,745800 & $393,10 * *$ & 0,00 \\
Tratamentos & 2 & 0,135666 & 0,067833 & $5,62 *$ & 2,31 \\
Resỉduo & 10 & 0,120728 & 0,012073 & & \\
\hline Total & 17 & 23,985400 & & & \\
\hline
\end{tabular}

Dados transformados para $\sqrt{\mathrm{x}+0,5}$

* - Ao nível de 5\% ao menos um contraste de mëdias difere de zero

Coeficiente de variação $=3,54763 \%$

Teste de Tukey 5\% para tratamentos

$\mathrm{DMS}=0,174044$

Tratamento $3=3,21492 \mathrm{~A}$

Tratamento $I=3,06844 \mathrm{AB}$

Tratamento $2=3,00816 \quad B$

Em relação ao nitrogênio amoniacal, à anālise estatistica dos resultados apresentados no Quadro 10, pela aplicação do Teste F, mostrou significância ao nĩvel de lo de probabilidade para os tratamentos. O teste de Tukey evidencia que a diferença entre os tratamentos é significativa a 5\% de probabilidade entre a testemunha e os demais tratamentos. Assim, é possível que uma fração do nitrogênio amoniacal se perca em função da elevação de $\mathrm{pH}$, entretanto, como a fração perdida representa muito pouco, sua participação em relação ao nitrogênio total, ainda aumenta, constituindo cerca de 19,3\%. 
o nitrogênio amoniacal representa menor fração do que no cal do tratado apenas texmicamente, e este fato poderä ser em função do conteũdo natural das amostras mais o percentual perdido decorrente da defecação.

Quadro 10 - Efeito da defecação simples do caldo no teor de ' nitrogênio amoniacal

\begin{tabular}{lccccc}
\hline Causa da variação & G.L. & S.Q. & Q.M. & F & Nível \\
\hline Blocos & 5 & 25,304800 & 5,060950 & $895,09 * *$ & 0,00 \\
Tratamentos & 2 & 0,127815 & 0,063908 & $11,30 * *$ & 0,27 \\
Resíduo & 10 & 0,056541 & 0,005654 & & \\
\hline Total & 17 & $25,489.100$ & & & \\
\hline
\end{tabular}

Dados transformados para $\sqrt{\mathrm{x} \times 0,5}$

** - Ao nível de 1\% ao menos um contraste de mëdias difere de zero Coeficiente de variação $=3,17311 \%$

Teste Tukey 5\% para tratamentos

DMS $=0,119108$

Tratamento $I=2,48786 \mathrm{~A}$

Tratamento $2=2,32418 \mathrm{~B}$

Tratamento $3=2,29714 \mathrm{~B}$ 


\subsubsection{Fosfatos}

Os resultados obtidos em relação aos teores de fosfatos jnorgānicos contidos nos caldos tratados por defecação simples a 5 e 60 minutos, a $100^{\circ} \mathrm{C}$, são apresentados na Tabela 11 .

Tabela 11 - Teor de fosfato inorgânico contido no caldo, em função da clarificação por defecação simples

\begin{tabular}{cccc}
\hline Amostra $^{*}$ & $\begin{array}{c}\text { Testemunha } \\
\text { ppm } \mathrm{P}_{2} \mathrm{O}_{5}\end{array}$ & $\begin{array}{c}5 \text { minutos } \\
\text { ppm } \mathrm{P}_{2} \mathrm{O}_{5}\end{array}$ & $\begin{array}{c}60 \text { minutos } \\
\mathrm{ppm}_{2} \mathrm{P}_{5}\end{array}$ \\
\hline 1 & 189,92 & 116,50 & 116,50 \\
2 & 254,54 & 176,22 & 176,22 \\
3 & 151,75 & 134,12 & 134,12 \\
4 & 204,81 & 109,78 & 99,64 \\
5 & 482,50 & 338,58 & 302,60 \\
6 & 410,18 & 347,80 & 320,13 \\
\hline Média & 282,28 & 203,83 & 191,53 \\
\hline
\end{tabular}

* O resultado de cada tratamento é média de 3 repetições.

A análise estatisticia, mostrada no Quadro Il, evidencia um valor de F significativo ao nível de lo de probabilidade para tratamentos, e o teste de Tukey mostra que a maior média, correspondente ao tratamento testemunha, difere significativamente ao nível de 5\% de probabilidade das amostras tratadas por defecação simples.

As diferenças entre as médias dos tratamentos

e (3) correspondentes a defecação por 5 e 60 minutos, estatisticamente, são não significativas. 
Quadro 11 - Teor de fosfato contido no caldo em função da clarificação por defecação simples

\begin{tabular}{lccccc}
\hline Causa da variação & G.L. & S.Q. & Q.M: & F & Nível \\
\hline Blocos & 5 & 195,323000 & 39,064600 & $65,68 * *$ & 0,00 \\
Tratamentos & 2 & 30,732900 & 15,366500 & $25,84 * *$ & 0,01 \\
Resíduo & 10 & 5,947270 & 0,594727 & & \\
\hline Trotal & 17 & 232,003000 & & & \\
\hline
\end{tabular}

Dados transformados para $\sqrt{x+0,5}$

** - Ao nivel de 1\% ao menos um contraste de médias difere de zero Coeficiente de variação $=5,27795 \%$

Teste de Tukey 5\% para txatamentos

$\mathrm{DMS}=1,22156$

Tratamento $I=16,44660 \mathrm{~A}$

Tratamento $2=13,88190 \mathrm{~B}$

Tratamento $3=13,50600 \mathrm{~B}$

A clarificação através da defecação simples está praticamente baseada no conteūdo de ions fosfato disponíveis e o cao que irá reagir, produzindo o precipitado de fosfato de cälcio, responsāvel pela adsorção de colōi des.

De modo geral, pode-se considerar o teor de fosfato satisfatório para a defecação proposta, uma vez que para defecação convencional, utilizada em usinas de açūcar, que é bastante enérgica' se comparada ao presente trabalho, o teor deverá estar no minimo 
a. 300 ppm de fosfato, segundo HONIG (1960); BENNETT e RAGNAUTH (1960); GUPTA et alii (1965); JANAKIRAMAIAH et alii (1967); PAYNE (1969); DELGADO et alii (1973a) e SILVA JR. (1976) e para obtenção de pH 6,0, a quantidade de CaO adi cionada ë bastante pequena.

Embora o teor de CaO adicionado seja bastante baixo, verifica-se que a remoção de $\mathrm{P}_{2} \mathrm{O}_{5}$ como precipitado de fosfato de cálcio foi da ordem de 78,45ppm, em média, para o tratamento (2), representando $28,74 \circ$ de remoção e 90,75 ppm para o tratamento (3), representando 31,93\%de remoção (Tabela 12).

Observa-se, ainda, que a remoção de $\mathrm{P}_{2} \mathrm{O}_{5}$ ocorreu grandemente jä nos primeiros 5 minutos a $100^{\circ} \mathrm{C}$ e que, praticamente, um tempo maior de tratamento não interfe riu no conteúdo removido, mostrando que na defecação, a maior importância está na temperatura e no pH a serem atingidos.

Segundo DAVIES (1969) e PAYNE (1969), a remoção de $\mathrm{P}_{2} \mathrm{O}_{5}$, numa eficiente clarificação, é da ordem de 80 a 90\% do fosfato existente. Como o presente estudo visa esclarecer o efeito dos tratamentos objetivando apenas purificação para obtenção de mosto, observa-se que nas condições experimentais, o teor de fosfato remanescente é da ordem de 65 a 70\%, praticamente suficiente para suprir as necessidades nutricionais das leveduras em fermentação al- 
coólica. Comparando-se os resultados dos tratamentos térmi cos com os da defeç̧ão simples, constata-se que no primeiro caso não houve remoção, e que a defecação promove redução de cerca de 25-30\% de fosfato. Ora, se a remoção de nitrogênio è da mesma ordem,e a diferença maior está no teor de fosfato removido, é lícito concluir-se que do ponto de vista da composição de um mosto favorável à fermenta ção, não se observa vantagem na defecação simples. Assim, em termos de condução de processo, há que se pesar outros parâmetros como redução de corrosão em equipamentos, facilidade de decantação e filtração, uso de insumos para tratamento e fermentação, e outros fatores que permitam cabal avaliação para a sua adoção.

Tabela 12 - Remoção de fosfato inorgânico do caldo, durante processo de defecação simples

\begin{tabular}{ccc}
\hline Amostra* & $\begin{array}{c}\text { Aquecimento } 5 \text { minutos } \\
\%\end{array}$ & $\begin{array}{c}\text { Aquecimento } 60 \text { minutos } \\
1\end{array}$ \\
\hline 2 & 38,65 & 38,65 \\
3 & 30,76 & 30,76 \\
4 & 11,61 & 11,61 \\
5 & 46,40 & 51,35 \\
6 & 29,82 & 37,28 \\
\hline Média & 15,21 & 21,95 \\
\hline
\end{tabular}

* Cada amostra é apresentada como média de 3 repetições. 
4.3.3. Contagem de Microorganismos

Como descrito no item 4.2.3., os ensaios de contagem microbiana foram efetuados separadamente apenas para verificar a redução da microflora em função dos tratamentos.

Os resultados estão apresentados na Tabela 13 e os dados analisados estatisticamente, representados no Quadro 12 e nos Quadros 24 a 32 constantes do Apêndice.

Em função do gradativo aquecimento até atingir a temperatura de $100^{\circ} \mathrm{C}$ e do resfriamento em āgua corrente, concorrendo para aumentar o tempo de residência a temperaturas próximas à ebulição, o efeito dos tratamentos foi bastante drāstico, reduzindo a população no tratamento (2) (5 minutos a $100^{\circ} \mathrm{C}$ ) ao nível do tratamento (3) (60 minu tos a $\left.100^{\circ} \mathrm{C}\right)$, o que se pode verificar pelas anālises estatísticas.

Esta sērie de experimentos, com caldos defecados, comportam-se praticamente como repetição do ensaio anterior, item 4.2.2, sendo as conclusões, absolutamente iguais às anteriores, inclusive no que tange aos coeficientes de variaçäo. 
Tabela 13 - População microbiana do caldo, apōs clarificação por defecação simples

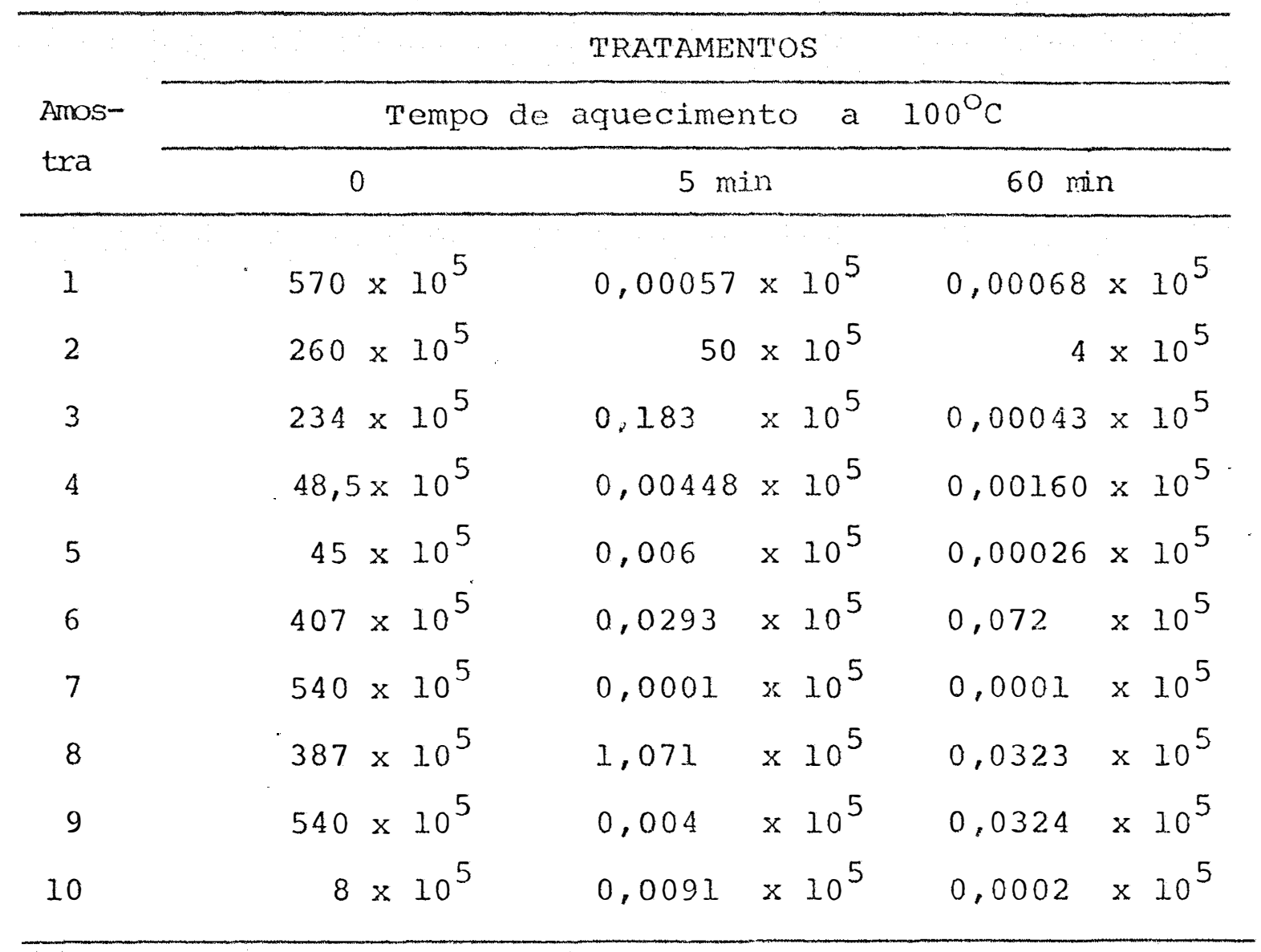

Quadro 12 - Efeito da defecação simples do caldo na popula ção microbiana

\begin{tabular}{lrrrrr}
\hline Causa da variaçäo & G.L. & S.Q. & Q.M. & F & Nivel \\
\hline Blocos & 9 & 200,028000 & 22.225300 & I, 07ns & 42,95 \\
Tratamentos & 2 & 1441,980000 & 720.990000 & $34,66^{* *}$ & 0,00 \\
Residuo & 18 & 374,415000 & 20,800800 & & \\
\hline Total & 29 & 2016,420000 & & & \\
\hline Dados transformados para $\sqrt{\mathrm{x}+0,5}$
\end{tabular}

** - Ao nível de 1\% ao menos um contraste de médias difere de zero Coeficiente de variaçäo $=75,5417 \%$

Teste de Tukey 5\% para tratamentos

DMS $=5,20652$

Tratamento $1=15,83680 \mathrm{~A}$

Tratamento $2=1,41734 \mathrm{~B}$

Tratamento $3=0,85818 \mathrm{~B}$ 


\section{4. Fermentació}

Os caldos testemunha, tratados termicamente e por defecação simples, discutidos até aqui, foram submetị dos à fermentação, em batelada, com a inoculação de $100 \mathrm{ml}$ de uma suspensão contendo $25 \mathrm{~g}$ de fermento comercial pren sado Fleischmann, previamente tratado a pH 2,5 com ácido sulfūrico.

$$
\text { Procurou-se estudar os possiveis efeitos }
$$

dos tratamentos sobre as eficiências fermentativas. Os vinhos obtidos a cada ensaio de fermentação foram analisados quanto ao teor de nitrogênio, fosfato, substâncias reduto ras residuais, teor alcoólico e massa celular. A fermentação foi deixada correr por cerca de 24 horas, não se determinando parâmetros cinéticos.

\subsubsection{Nitrogênio}

Em relação ao nitrogênio e suas formas, tal como foi determinado, observa-se que a variação entre cada amostra ensaiada é muito grande (Tabelas 14 e 15) e de difícil interpretação, pouco se encontrando como parâmetros comparativos na literatura.

De uma maneira geral, o nitrogênio total exis tente no caldo é reduzido pela fermentação, encontrando -se, entretanto, teores muito variáveis no vinho, se, por um lado, 
é esperada a remoção de nitrogênio do caldo pela utilização do elemento pelos microorganismos, há também, por outro lado, autólise destes microorganismos, adsorção de proteínas junto aos microorganismos durante a separação por centrifugação, precipitação por ponto isoelétrico em função do pH do vinho, entre outros fatores.

Segundo HARRISON (1971), o nitrogênio conti dó na levedura é de 7,5 a 9,0 g/100 g de matéria seca. Admi tindo-se que cada $100 \mathrm{~g}$ de açúcares totais gere cerca de 1,9 g de matéria seca, em fermentação, teríamos um consumo de cerca de $0,17 \mathrm{~g}$ de nitrogênio nessas condições ou nas condições experimentais, de 0,118 a 0,188 g N, o que representaria cerca de 23,6 a 37,6 mg N/100 ml de redução de nitrogênio total, o que nem sempre se verificou. possivel constatar ainda que quando os teores de nitrogênio no caldo são baixos, os valores encontrados no vinho não diferem substancialmente daquele, dificultando a interpretação, que poderia ser uma consequência do método analítico, cuja sensibilidade a esses níveis se torna crítica.

Em relação às formas amoniacal, protéica e não protēica, suas variações podem ser em decorrência da transformação metabólica realizada pelos microorganismos. Assim, uma redução do nitrogênio amoniacal pode ser uma consequência de sua assimilação e transformação em aminoāci dos ou proteínas. Note--se que em alguns casos houve redução, 
em outros, manutenção e até acréscimo da forma não protéica que poderia significar um momento biológico onde produtos metabólicos como aminoácidos e $\mathrm{NH}_{4}^{+}$poderiam estar sendo liberados ao meio (SUOMALAINEN e OURA, 1971).

Observa-se, portanto, que em relação ao nitrogênio, nenhuma diferença parece existir, em termos de comportamento metabólico, que permita diferenciar uma fer mentação com caldo não tratado, tratado termicamente e por defecação simples.

\subsubsection{Fosfatos}

Em relação aos fosfatos, observa-se que a ri queza em $\mathrm{P}_{2} \mathrm{O}_{5}$ dos caldos forneceram sempre teores satisfató rios à fermentação, segundo JONES et alii (198I), STUPIELLO e HORII (1981).

Os teores de fosfato nos vinhos e os consu mos expressos em ppm de $\mathrm{P}_{2} \mathrm{O}_{5}$, apresentados as Tabelas $16 \mathrm{e}$ 17 mostram que para o tratamento térmico e a defecação simples, os consumos de fosfato variam de forma idêntica, isto é, parece não existir qualquer influência dos tratamentos sobre o consumo. Somente tratamentos testemunhas, nos dois casos em estudo, apresentaram valores por vezes maiores, que poderiam ser decorrentes de maior adsorção, como levantado por LOPES et alii (1984).' 
Assim, pode-se verificar que os tratamentos praticamente não influiram no comportamento das leveduras em relação ao consumo de fosfatos. 


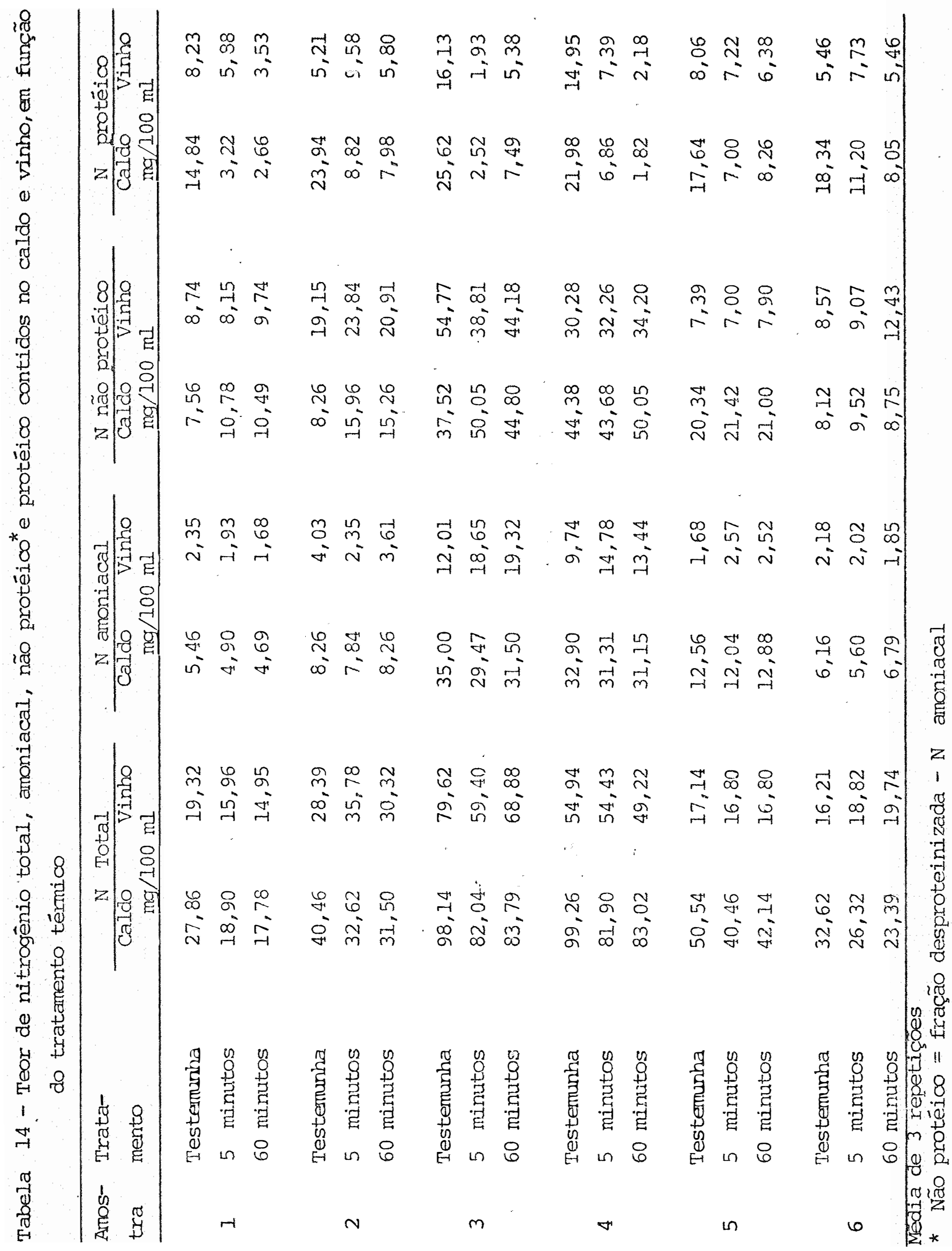




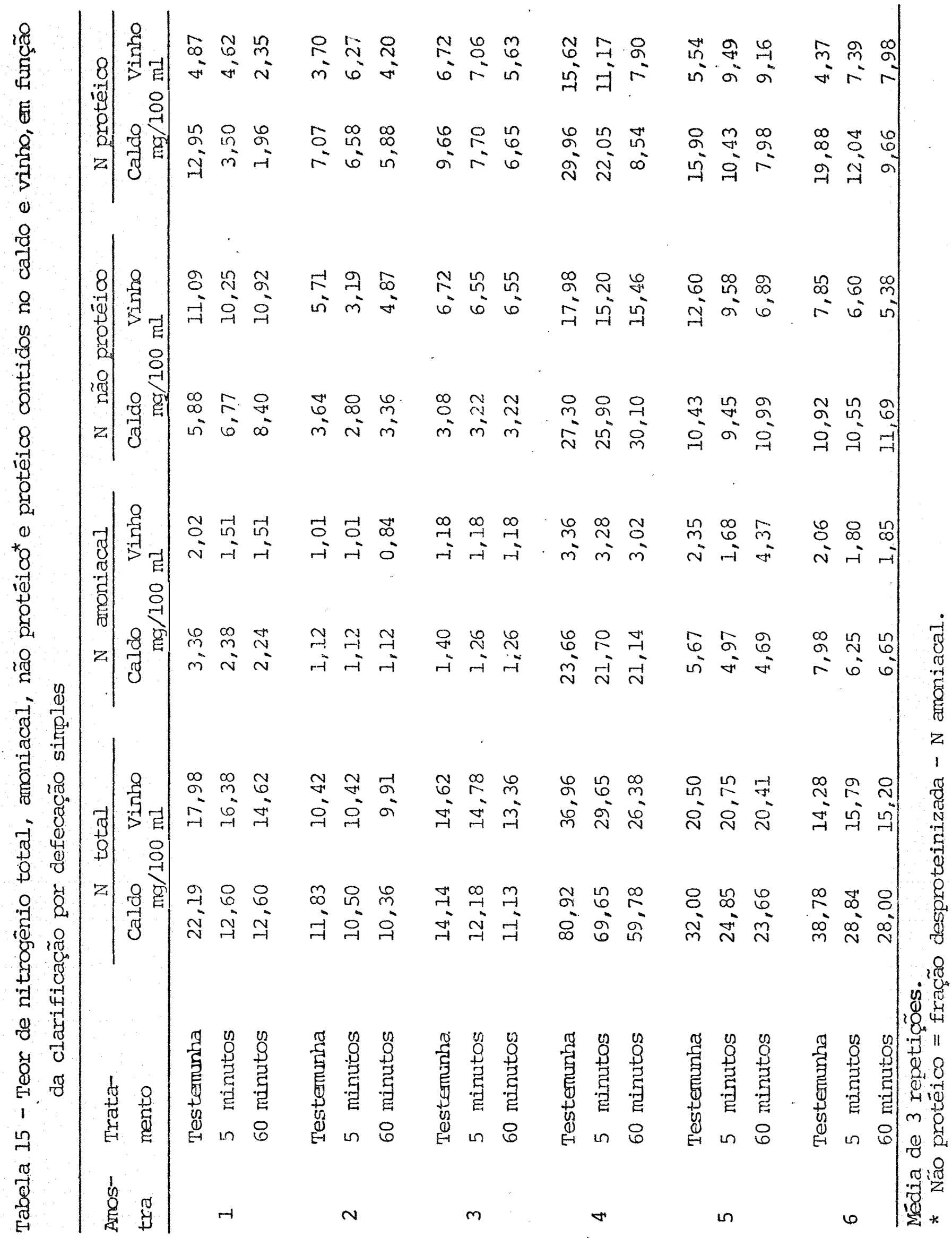


Tabela 16 - Teor de fosfato inorgânico contido no vinho e consumido em função do tratamento tērmico

\begin{tabular}{|c|c|c|c|c|c|c|}
\hline \multirow[b]{2}{*}{ Amostra } & \multicolumn{2}{|c|}{ Testemunha } & \multicolumn{2}{|c|}{5 minutos } & \multicolumn{2}{|c|}{60 minutos } \\
\hline & $\begin{array}{l}\mathrm{P}_{2} \mathrm{O}_{5} \text { con- } \\
\text { sumido } \\
\text { ppm }\end{array}$ & $\begin{array}{c}\mathrm{P}_{2} \mathrm{O}_{5} \text { no } \\
\text { vinho } \\
\text { ppm } \\
\end{array}$ & $\begin{array}{l}\mathrm{P}_{2} \mathrm{O}_{5} \text { con } \\
\text { sumido } \\
\text { ppm }\end{array}$ & $\begin{array}{l}\mathrm{P}_{2} \mathrm{O}_{5} \text { no } \\
\text { vinho } \\
\text { ppm } \\
\end{array}$ & $\begin{array}{l}\mathrm{P}_{2} \mathrm{O}_{5} \text { onn } \\
\text { sumido } \\
\text { ppom }\end{array}$ & $\begin{array}{l}\mathrm{P}_{2} \mathrm{O}_{5} \text { no } \\
\text { vinho } \\
\text { penn }\end{array}$ \\
\hline 1 & 159,93 & 89,26 & 123,16 & 101,03 & 116,12 & 108,07 \\
\hline 2 & 283,29 & 166,39 & 161,31 & 333,37 & 107,23 & 328,69 \\
\hline 3 & 161,14 & 158,99 & 152,60 & 158,30 & 126,10 & 184,80 \\
\hline 4 & 46,51 & 158,30 & 102,21 & 89,68 & 102,21 & 89,68 \\
\hline 5 & 166,06 & 66,42 & 168,64 & 55,46 & 162,19 & 56,46 \\
\hline 6 & 350,02 & 119,56 & 235,81 & 184,88 & 221,42 & 199,27 \\
\hline
\end{tabular}

Tabela 17 - Teor de fosfato inorgânico contido no vinho e consumido em função do processo de defecaçăo simples

\begin{tabular}{|c|c|c|c|c|c|c|}
\hline \multirow[b]{2}{*}{ Amostra } & \multicolumn{2}{|c|}{ Testemunha } & \multicolumn{2}{|c|}{5 minutos } & \multicolumn{2}{|c|}{60 minutos } \\
\hline & $\begin{array}{l}\mathrm{P}_{2} \mathrm{O}_{5} \mathrm{con-} \\
\text { sumido } \\
\text { ppm } \\
\end{array}$ & $\begin{array}{l}\mathrm{P}_{2} \mathrm{O}_{5} \text { no } \\
\text { vinho } \\
\text { ppm }\end{array}$ & $\begin{array}{l}\mathrm{P}_{2} \mathrm{O}_{5} \mathrm{Con}^{-} \\
\text {sumido } \\
\text { pprn } \\
\end{array}$ & $\begin{array}{l}\mathrm{P}_{2} \mathrm{O}_{5} \text { no } \\
\text { vinho } \\
\text { ppm }\end{array}$ & $\begin{array}{l}\mathrm{P}_{2} \mathrm{O}_{5} \mathrm{COn}^{-} \\
\text {sumici } \\
\text { ppm }\end{array}$ & $\begin{array}{l}\mathrm{P}_{2} \mathrm{O}_{5} \text { no } \\
\text { vinho } \\
\text { ppm } \\
\end{array}$ \\
\hline 1 & 106,51 & 83,41 & 50,72 & 65,78 & 56,58 & 59,92 \\
\hline 2 & 177,01 & 77,53 & 110,44 & 65,78 & 110,44 & 65,78 \\
\hline 3 & 91,83 & 59,92 & 74,00 & 59,92 & 74,20 & 59,92 \\
\hline 4 & 91,89 & 112,92 & 43,36 & $66,42^{\circ}$ & 37,65 & 61,99 \\
\hline 5 & 324,20 & 158,30 & 236,74 & 101,84 & 212,94 & 89,66 \\
\hline 6 & 188,34 & 221,84 & 154,74 & 193,06 & 133,71 & 186,42 \\
\hline
\end{tabular}




\subsubsection{Massa Celular}

Procedeu-se também a determinação da massa celular seca no vinho das amostras fermentadas durante 24 horas com inóculo constituído de $25 \mathrm{~g}$ de fermento prensado suspensos em água num volume total de $100 \mathrm{ml}$.

A análise do peso seco foi realizado segundo o método descrito em Material e Métodos.

Os resultados obtidos são apresentados nas Tabelas 18 e 19, correspondentes aos tratamentos térmico e por defecação simples, respectivamente.

Partindo-se do princípio que a cada $100 \mathrm{~g}$ de ART fermentado em meio totalmente anaeróbico, há a formação de 1,9 g de material celular, calculou-se um valor teórico de massa.

Observa-se que houve uma variação grande en tre as amostras e que o valor encontrado para a testemunha tende a ser maior que o encontrado para os tratamentos tan to tērmico quanto defecação. Na prática, observa-se que a testemunha tende a acumular mais impurezas ou borras, não elimináveis por lavagem e filtração do que os caldos tratados. Assim, o teor de impurezas coloidais, precipitadas ou adsorvidas, retidas pelo filtro Millipore tipo $A A$, com 0,8 $\mu \mathrm{m}$ de porosidade, $47 \mathrm{~mm}$ de diâmetro mascararam grandemente os resultados, impedindo o estudo de incremento de massa 
celular em meios naturais como o caldo. E possivel que tratamentos com álcalis possam contribuir para melhorar a recu peração a avaliação do fermento, entretanto, experimentos dessa natureza contam ainda com dificuldades como a perfeita homogeneização da amostra no momento da coleta da alíquo ta a sex analisada. Fica, portanto, prejudicada uma inter pretação da influência dos teores principalmente de nitrogê nio em relação ao crescimento e produção de ālcool, bem como porque uma série de inibidores de crescimento e da fer mentação não foram determinadas e suas influências somente poderiam ser melhor detectadas em fermentação continua em quimiostato, em regime estacionário.

Tabela 18 - Influência do tratamento térmico na produção de massa celular

\begin{tabular}{|c|c|c|c|c|c|c|}
\hline $\begin{array}{l}\text { Amos- } \\
\text { tra }\end{array}$ & $\begin{array}{l}\text { Teste- } \\
\text { munha } \\
\mathrm{g} / 100 \mathrm{mI}\end{array}$ & $\begin{array}{l}5 \text { minu- } \\
\text { tos } \\
\mathrm{g} / 1.00 \mathrm{ml}\end{array}$ & $\begin{array}{l}60 \text { minu- } \\
\text { tos } \\
\mathrm{g} / 100 \mathrm{ml}\end{array}$ & $\begin{array}{l}\text { Mëdia da } \\
\text { massa ce } \\
\text { lular ob } \\
\text { tida } \\
\text { g/loo ml }\end{array}$ & $\begin{array}{l}\text { Mëdia da } \\
\text { massa ce- } \\
\text { lular teó } \\
\text { rica } \\
\text { 9/100 ml }\end{array}$ & $\begin{array}{c}\text { Média do } \\
\text { AITT } \\
\mathrm{p} / \mathrm{p}\end{array}$ \\
\hline 1 & 1,912 & 2,209 & 2,177 & 2,099 & 1,7318 & 19,61 \\
\hline 2 & 1,605 & 1,372 & 1,340 & 1,439 & 1,6608 & 15,69 \\
\hline 3 & 1,374 & 1,335 & 1,300 & 1,336 & ]., 6774 & 16,62 \\
\hline 4 & 1,684 & 1,540 & 1,603 & 1,609 & 1,6650 & 15,88 \\
\hline 5 & 1,757 & 1,441 & 1,528 & 1,575 & 1,6600 & 15,66 \\
\hline 6 & 1,844 & 1,656 & 1,586 & 1,695 & 1,6503 & 15,15 \\
\hline
\end{tabular}


Tabela 19 - Influéncia da defecação simples na produção de massa celular

\begin{tabular}{|c|c|c|c|c|c|c|}
\hline $\begin{array}{l}\text { Amos- } \\
\text { tra }\end{array}$ & $\mathrm{g} / 100 \mathrm{ml}$ & $\begin{array}{l}5 \text { minu- } \\
\text { tos } \\
9 / 100 \mathrm{ml}\end{array}$ & $\begin{array}{l}60 \text { minu- } \\
\text { tos } \\
g / 100 \mathrm{ml}\end{array}$ & $\begin{array}{l}\text { Média da } \\
\text { massa ce- } \\
\text { lular ob- } \\
\text { tida } \\
\text { g/100 ml } \\
\end{array}$ & $\begin{array}{c}\text { Média da } \\
\text { massa ce- } \\
\text { lular teó } \\
\text { rica } \\
9 / 100 \mathrm{ml}\end{array}$ & $\begin{array}{c}\text { Média do } \\
\text { ART } \\
\mathrm{p} / \mathrm{p}\end{array}$ \\
\hline 1 & 2,418 & 2,247 & 2,439 & 2,368 & 1,7417 & $20,3.6$ \\
\hline 2 & 1,767 & 1,690 & 1,611 & 1,689 & 1,7292 & 19,51 \\
\hline 3 & 1,873 & 1,826 & 1,835 & 1,845 & 1,7299 & 19.53 \\
\hline 4 & 1,553 & 1,573 & 1,537 & 1,554 & 1,6735 & 16,39 \\
\hline 5 & 1,812 & 1,522 & 1,622 & 1,652 & 1,6304 & 14,01 \\
\hline 6 & 1,846 & 1,761 & 1,620 & 1,742 & 1,6162 & 13,19 \\
\hline
\end{tabular}

4.4.4. Eficiência de Fermentação e de Conversão

Considerando que cada amostra não era repetição, pois tinha um teor de açūcares totais diferente que variou de 13,09 a $20,24 \mathrm{~g} / 100^{\circ} \mathrm{g}$ e que gerou um teor alcoólico de 5,30 a 8,60\%, em peso, correspondentes a 6,64 a $10,72 \%$ em volume, foi calculada a eficiência de fermentação e conversão. Denominou-se eficiência de fermentação à relação percentual entre o álcool produzido e o álcool teórico passí vel de ser obtido a partir do açücar total contido no mosto, baseado na relação estequiométrica da equação de Gay-Lussac. Denominou-se eficiência de conversão, à eficiência calculada com base no açúcar total consumido, ou seja, a diferença en- 
tre o açücar total. do mosto e o total de açūçares residuais encontrados no vinho.

Observa-se nas Tabelas 20 a 25 que os teores de açūcares totais do mosto não influíram basicamente no teor alcoölicó a ponto de levarem à fermentação incompleta pois os teores de açūcares residuais quando diferiram entre tratamentos, ocorreu de forma fortuita, sendo provavelmente decorrente do momento considerado final da fermentação.

Verifica-se que os tratamentos térmicos e a defecação simples não diferiram entre si e nem em relação à testemunha no que tange as eficiências de fermentação e conversão (Tabelas 26 e 27).

Os Quadros 13 a 16 mostram a estatistica apli cada aos resultados, demonstrando a afirmação anterior.

Em parte, é possível que a não diferenciação entre os valores discutidos se deva tambēm à eficácia do tratamento do fermento, indiretamente, mantendo pH em torno de 4,0 nas testemunhas, enquanto nas amostras tratadas, independente do pH, o nível de contaminantes tenha se mantido em proporções desprezíveis em virtude da eficiência dos tratamentos térmicos não interferindo na transformação de aç $\bar{u}$ car em álcool pelias leveduras. Aliás, sobre este assunto, BRYAN-JONES (1975) mostra com muita propriedade a influência do abaixamento do pH sobre o tempo de geração de bactérias 
láticas, enquanto YAROVEnKo (1964) e HARRISON e GRAHAM(1970) chamam a atenção para o fato de que alta densidade de levedu ras no meio de fermentação mantém as bactérias contaminantes do ácido lático e do ácido acético com poucas possibilidades de desenvolvimento, relatando que baixo inóculo, da ordem de 2 a $3 \times 10^{6}$ células por ml no meio de fermentação são mais sensíveis a infecção por bactérias láticas e outras organismos. Calculando-se, no mínimo, $10^{10}$ células por grama de fermento prensado, o inóculo utilizado no presente traba lho representa cerca de $25 \times 10^{8}$ células por mililitro, capazes de-garantir uma fermentação de poucos riscos, segundo os autores anteriormente citados. 


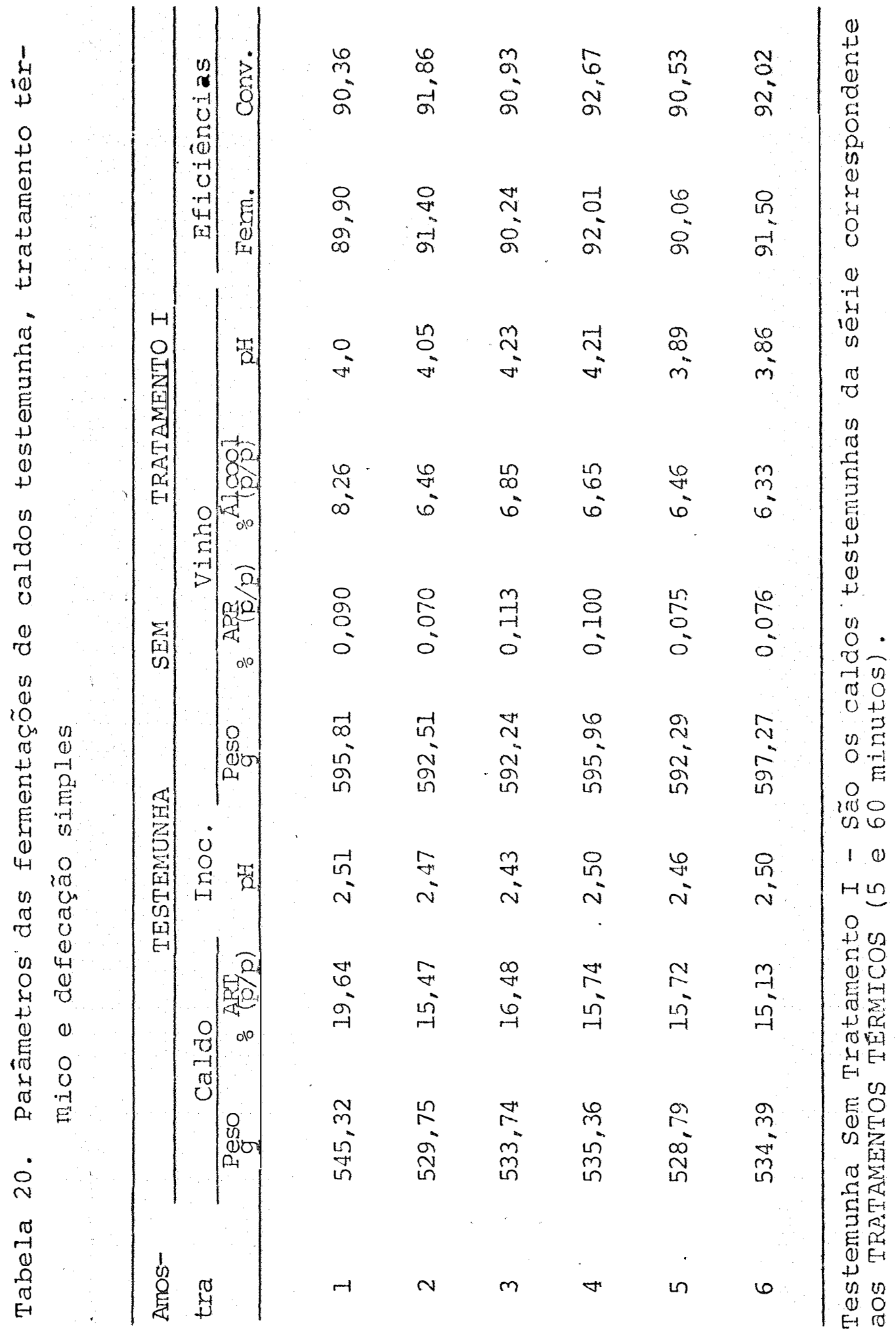




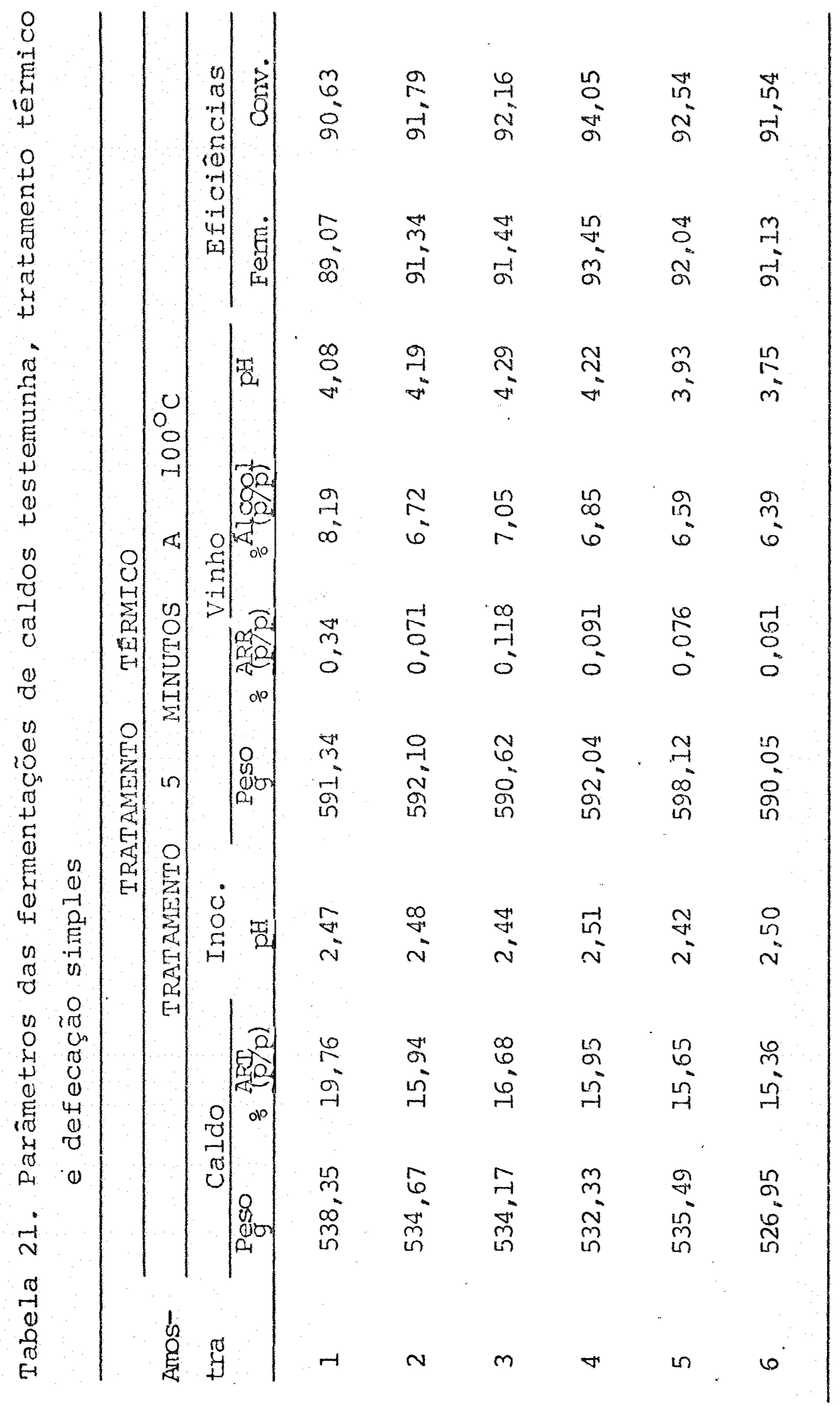




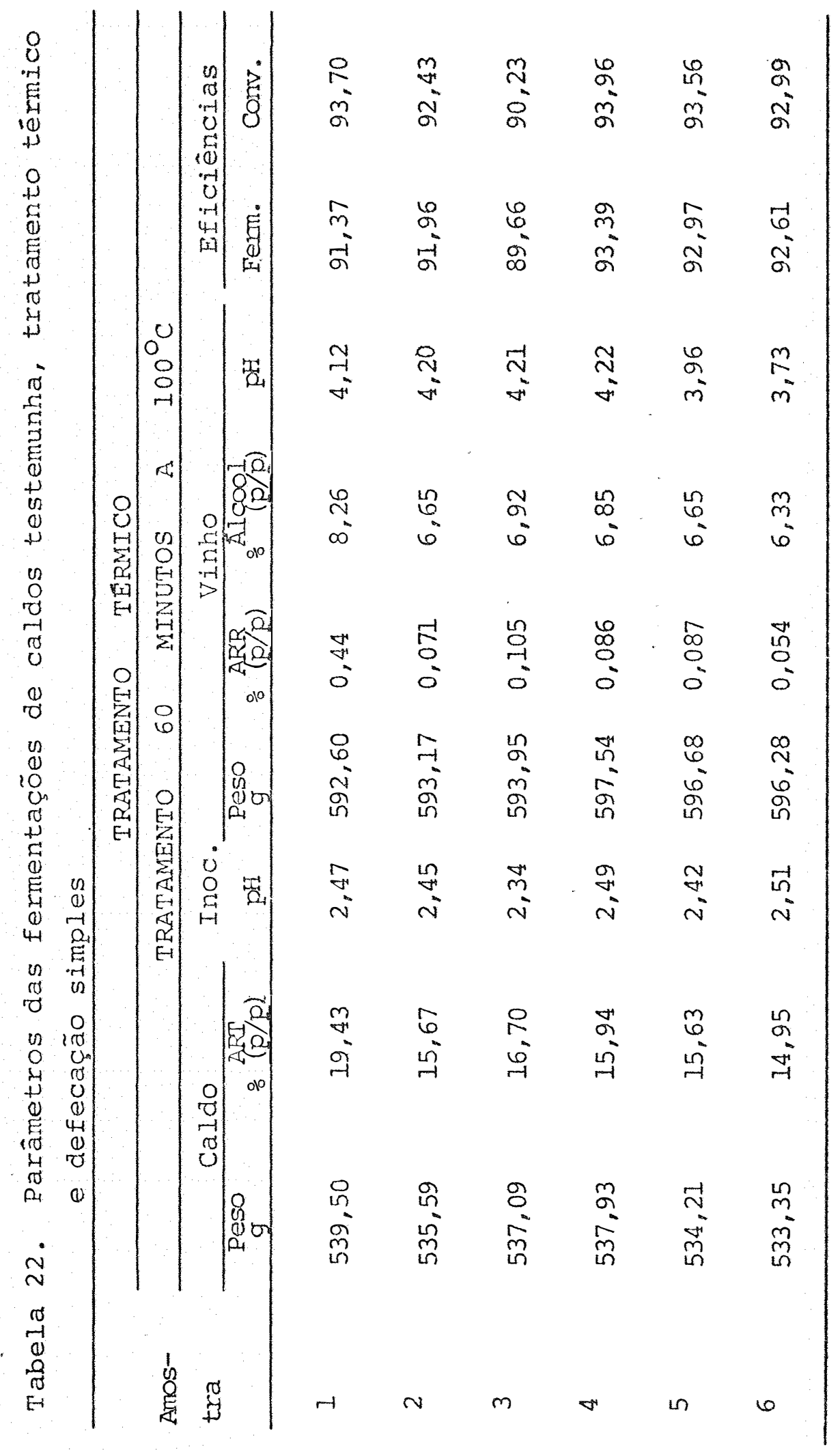




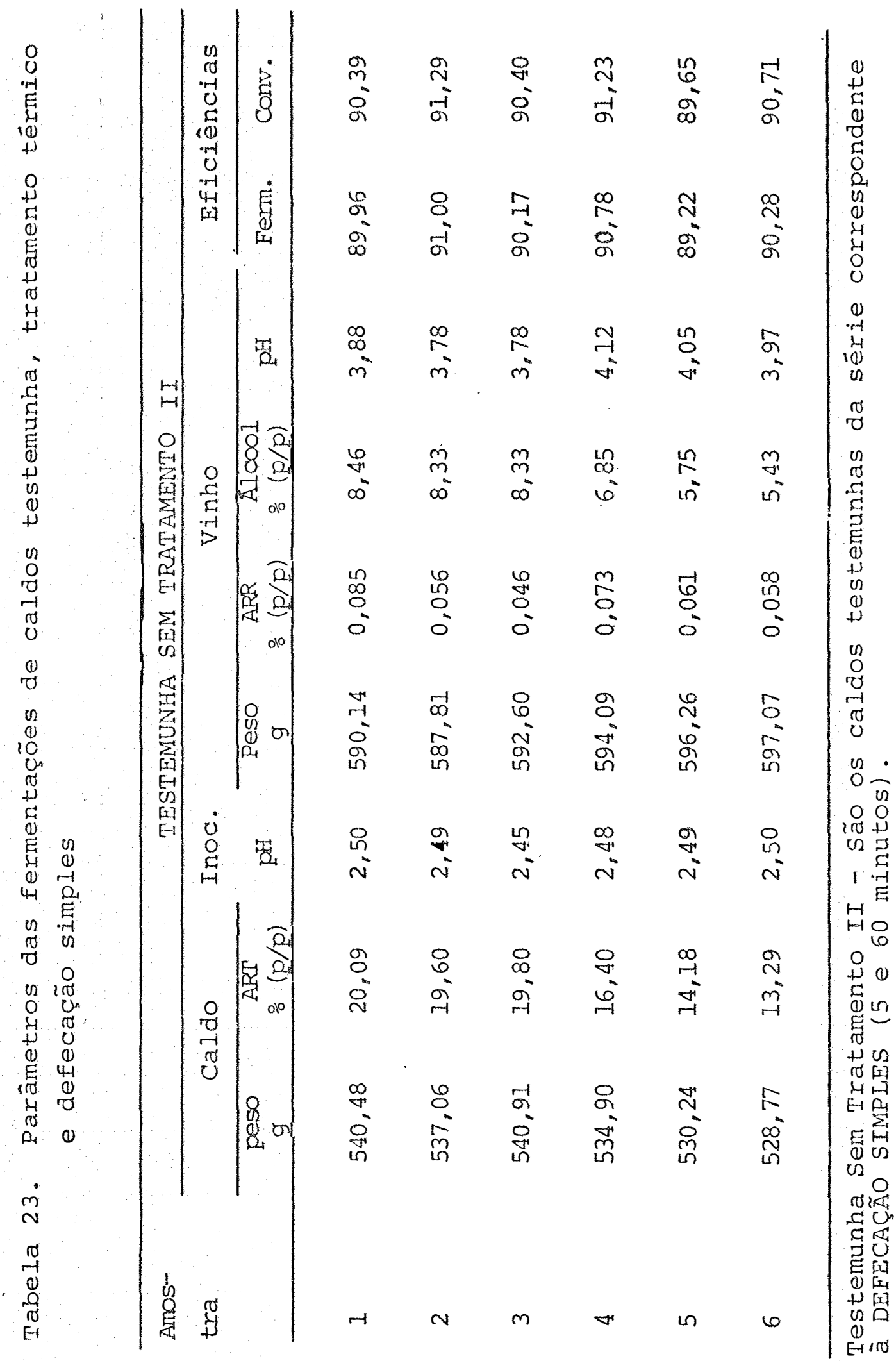




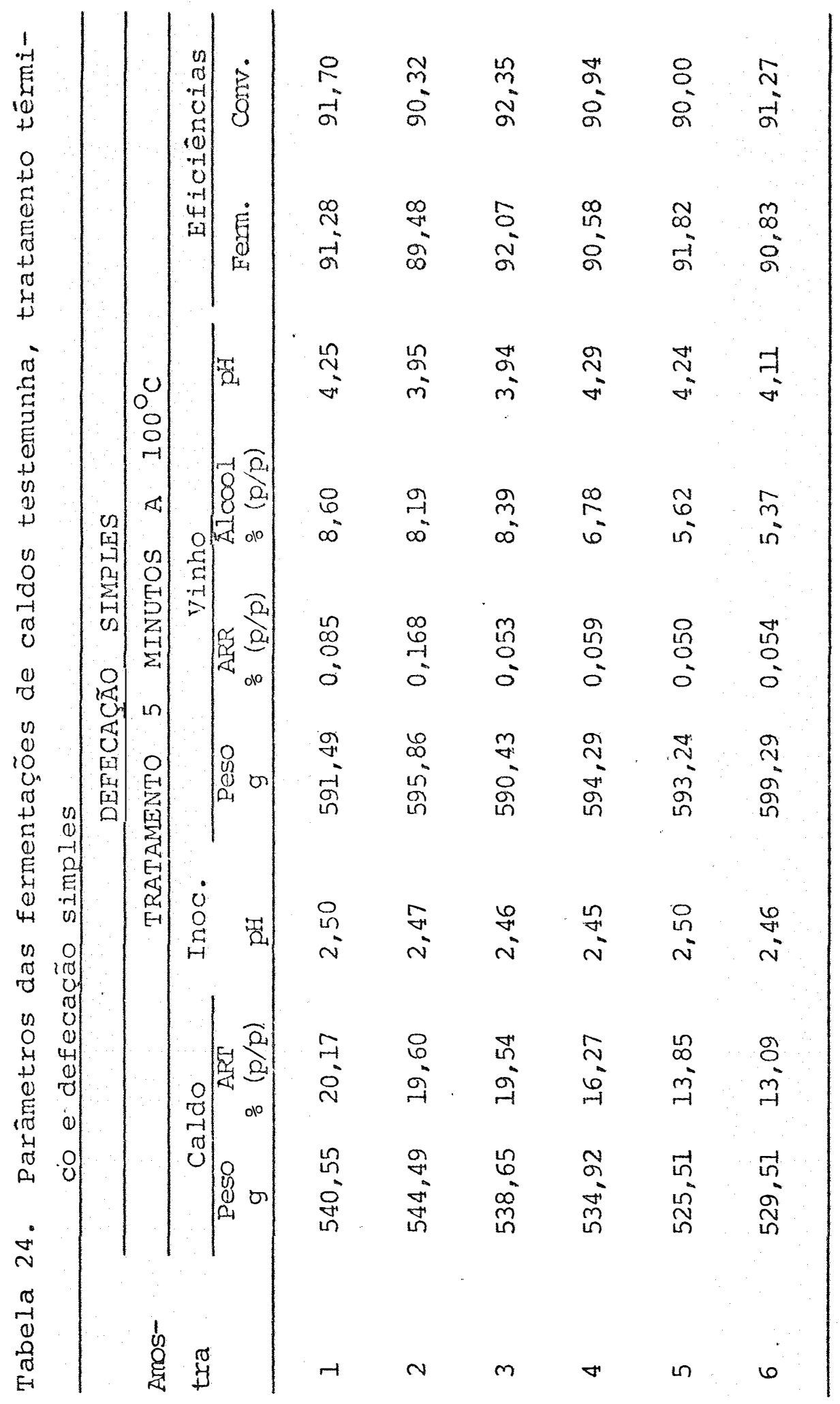




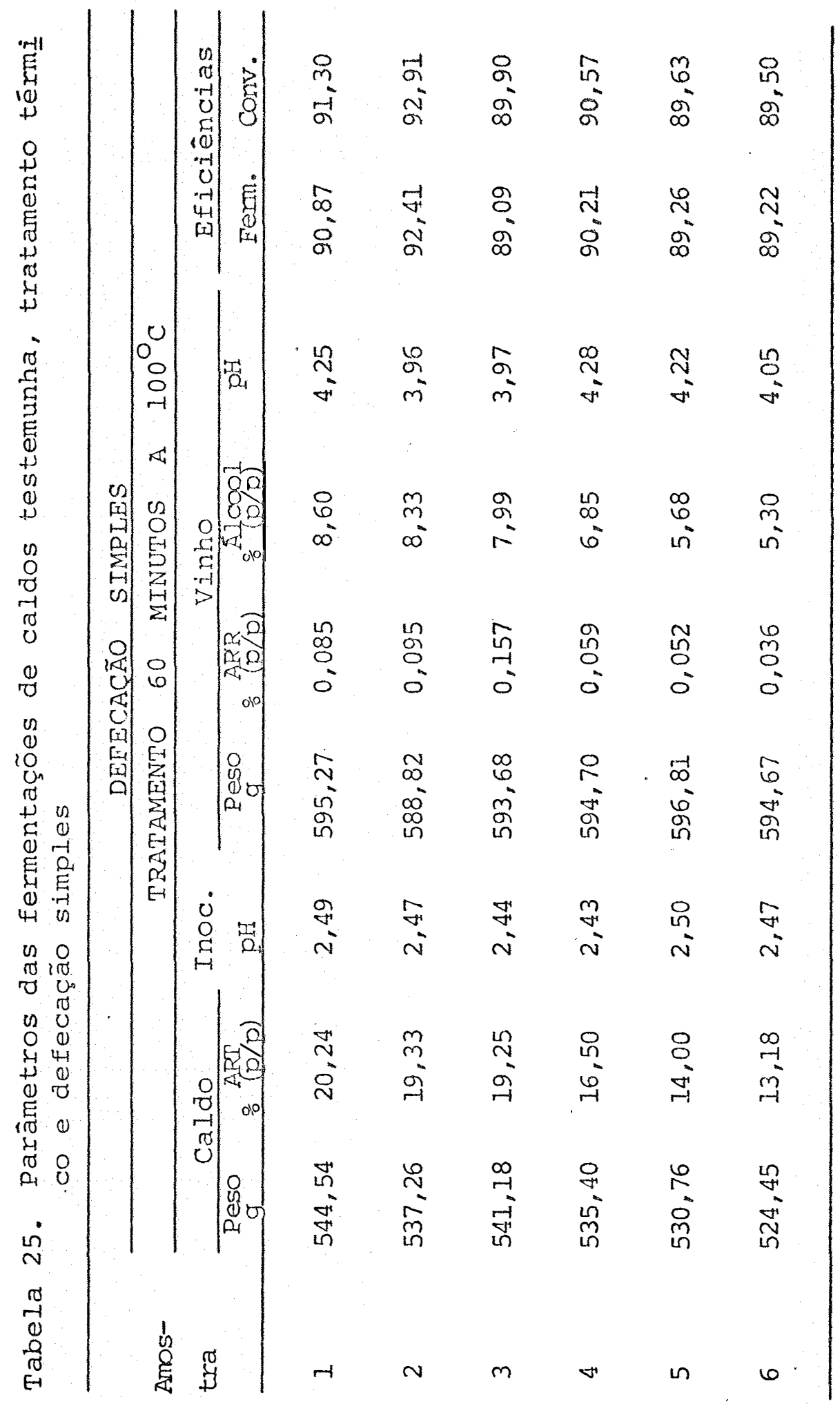




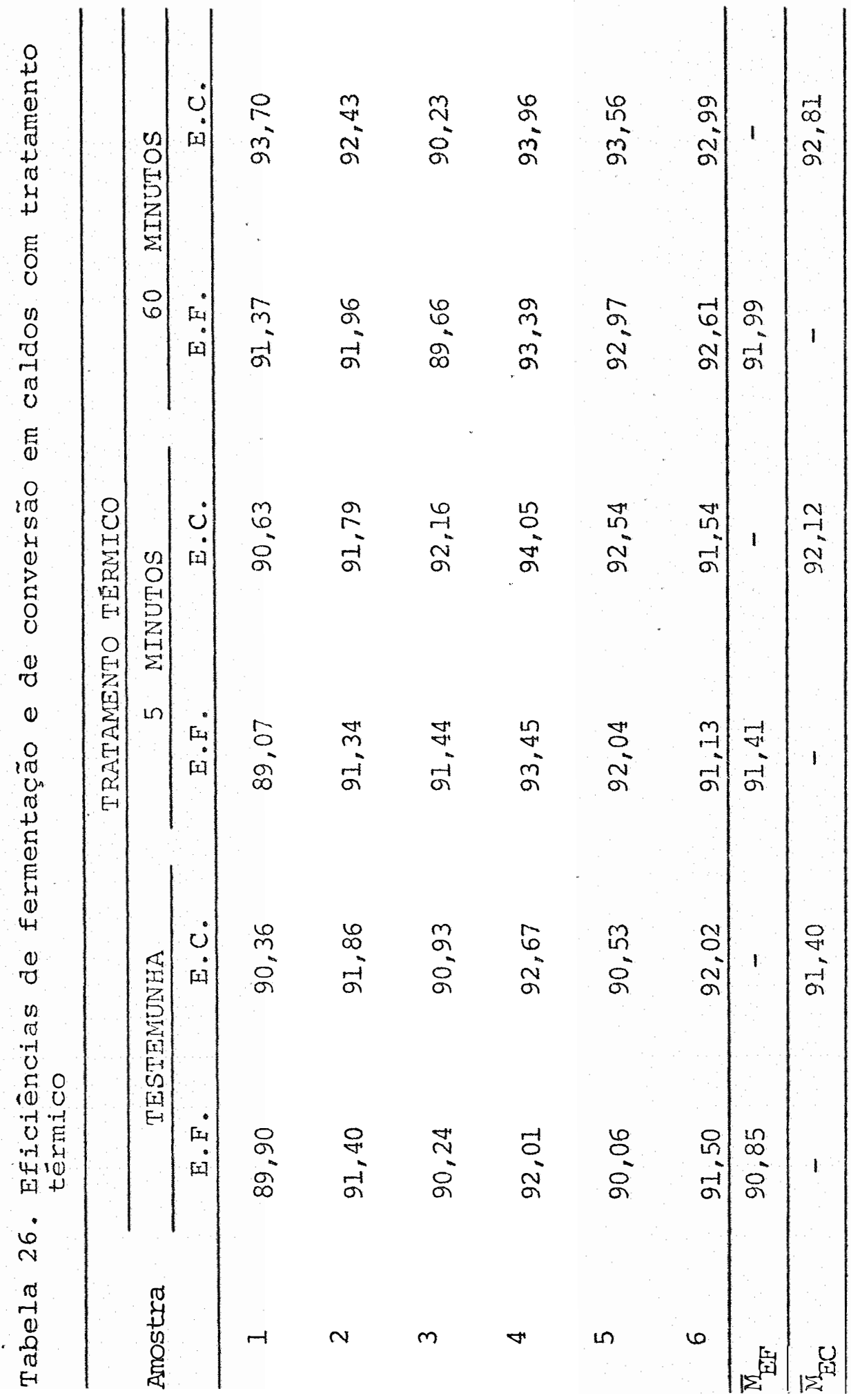




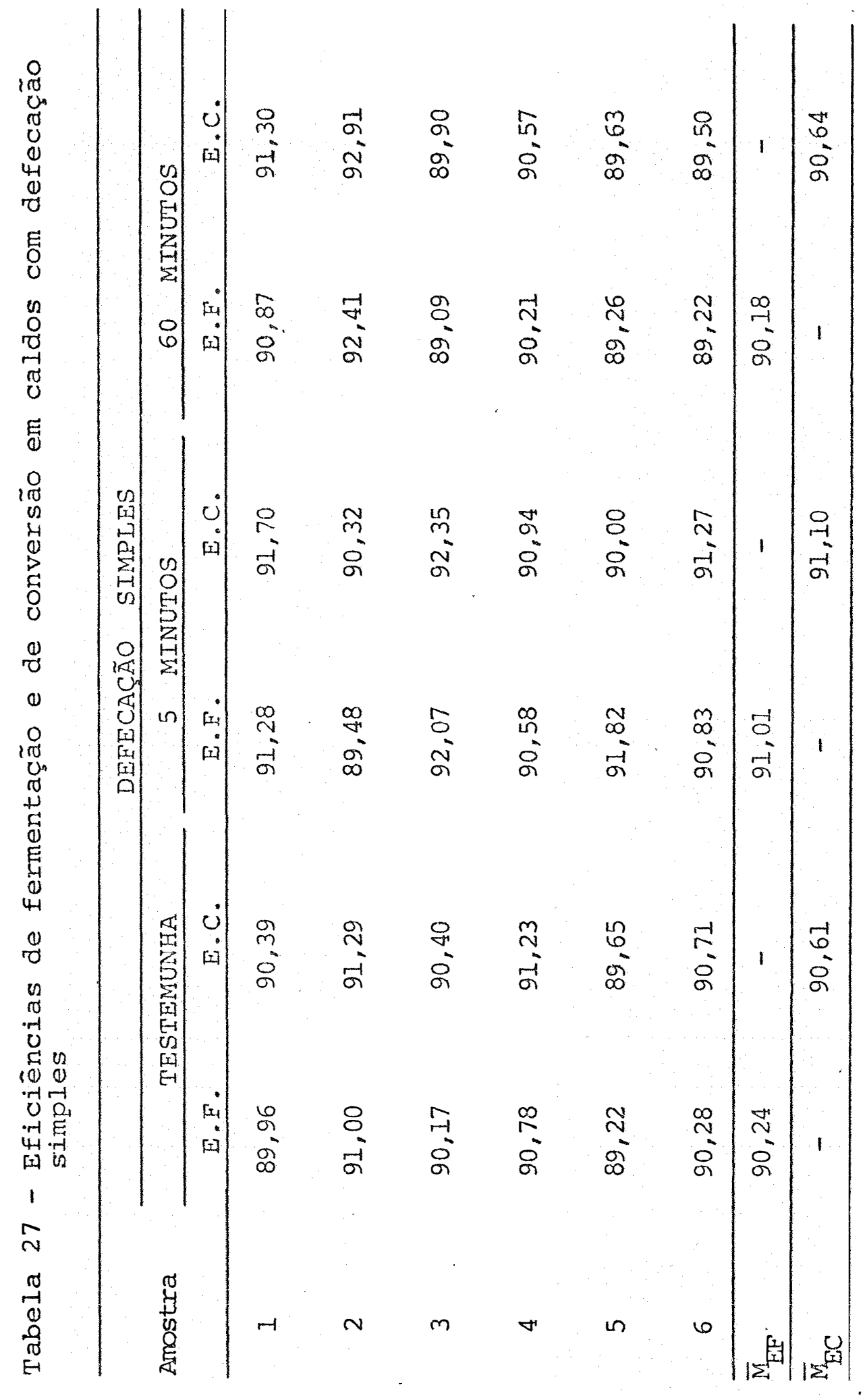


Quadro 13 - Eficiência de fermentação em caldos com tratamen to tërmico

\begin{tabular}{lccccc}
\hline Causa da variação & G.L. & S.Q. & Q.M. & F & Nível \\
\hline Blocos & 5 & 0,042847 & 0,008569 & $4,39 *$ & 2,25 \\
Tratamentos & 2 & 0,012475 & 0,005737 & 2,94 ns & 9,92 \\
Residuo & 10 & 0,019531 & 0,001953 & & \\
\hline Total & 17 & 0,073853 & & & \\
\hline
\end{tabular}

Dados transformados para $\sqrt{\mathrm{x}+0,5}$

Coeficiente de variação $=0,46097 \%$

Teste de Tukey 5\% para tratamentos

DMS $=0,0700037$

Tratamento $3=9,61713 \mathrm{~A}$

Tratamento $2=9,58682 \mathrm{~A}$

Tratamento $l=9,55771$ A

Quadro 14 - Eficiência de conversão em caldos com tratamento térmico

\begin{tabular}{lccccc}
\hline Causa da variação & G.L. & S.Q. & Q.M. & F & Nível \\
\hline Blocos & 5 & $0,02941.9$ & 0,005884 & $2,37 n s$ & 11,46 \\
Tratamentos & 2 & 0,017822 & 0,008911 & $3,60 \mathrm{~ns}$ & 6,66 \\
Resĩduo & 10 & 0,024780 & 0,002478 & & \\
\hline Total & 17 & 0,072021 & & & \\
\hline
\end{tabular}

Dados transformados para $\sqrt{x+0,5}$

coeficiente de variação $=0,517294 \%$

Teste Tukey 5\% para tratamentos

DMS $=0,0788514$

Tratamento $3=9,65958 \mathrm{~A}$

Tratamento $2=9,62369 \mathrm{~A}$

Tratamento $]=9,58609 \mathrm{~A}$ 
Quadro 15 - Eficiência de fermentação em caldos com defecação simples

\begin{tabular}{lccccc}
\hline Causa da variação & G.I. & S.Q. & Q.M. & F & Nĩvel \\
\hline Blocos & 5 & 0,005127 & 0,001025 & $0,29 n s$ & 90,57 \\
Tratamentos & 2 & 0,007813 & 0,003906 & $1,12 n s$ & 36,43 \\
Resíduo & 10 & 0,034912 & 0,003491 & & \\
\hline Total & 17 & 0,047852 & & & \\
\hline
\end{tabular}

Dados transformados para $\sqrt{\mathrm{x}+0,5}$

Coeficiente de variação $=0,619492 \%$

Teste Tukey 5\% para tratamentos

DMS $=0,0935932$

Tratamento $2=9,56598 \mathrm{~A}$

Tratamento $I=9,52545 \mathrm{~A}$

Tratamento $3=9,52223 \mathrm{~A}$

Quadro 16 - Eficiência de conversão em caldos com defecação simples

\begin{tabular}{lccccc}
\hline Causa da variação & G.L. & S.Q. & Q.M. & $F$ & Nivel \\
\hline Blocos & 5 & 0,014893 & 0,002979 & $1,26 \mathrm{~ns}$ & 35,32 \\
Tratamentos & 2 & 0,002075 & 0,001038 & $0,44 \mathrm{~ns}$ & 65,70 \\
Resíduo & 10 & 0,023682 & 0,002368 & & \\
\hline Total & 17 & 0,040649 & & & \\
\hline
\end{tabular}

Dados transformados para $\sqrt{\mathrm{x}+0,5}$

Coeficiente de variação $=0,509355 \%$

Teste Tukey 5 para tratamentos

DMS $=0,0770836$

Tratamento $2=9,57053 \mathrm{~A}$

Tratamento $3=9,54627 \mathrm{~A}$

Tratamento $I=9,54520 \mathrm{~A}$ 


\section{Conclusões}

A série de experimentos realizados, em condições de laboratório, para aquilatar a influência de trata mentos térmicos e defecação simples sobre a composição de substâncias nitrogenadas e fosfato inorgânico do caldo de cana e fermentação alcoólica conduzida por esta matéria-prị ma permitiram chegar às conclusões que se seguem:

- o Tratamento térmico e a defecação simples levaram a resultados similares quanto à remoção de nitrogênio total.

- o teor de nitrogênio amoniacal permaneceu praticamente inalterado em função da defecação e dos tratamentos térmicos.

- A remoção de nitrogênio protéico foi inferior na defecação simples, em relação ao tratamento térmico.

- Houve acréscimo da fração não protéica, após 
tratamentos térmicos, concorrendo para um aumento na fração de nitrogênio disponível à fermentação. Ao contrário da defecação simples, em que o teor de nitrogênio não protéico permaneceu praticamente inalterado.

- A remoção de fosfato inorgânico

ocorreu significativamente na defecação simples, enquanto nos tratamentos térmicos isso não se verificou.

- A redução da população microbiana pela defecação simples foi absolutamente igual à encontrada no tratạ mento térmico.

- Os teores de nitrogênio e fosfato nos caldos tratados termicamente e por defecação simples, não influiram nas eficiências fermentativas e de conversão.

- As alterações químicas ocorridas nos caldos tratados como foram descritos nestes experimentos, não interferiram no comportamento fermentativo das leveduras, embora não tenha sido analisada sob aspecto cinético.

As vantagens e desvantagens dos tratamentos em caráter industrial deverão ser estudadas sob aspectos físicos, de remoção de impurezas sólidas insolúveis, de corrosão de equipamentos, de consumo de insumos, de ordem econômica e particularidades de processo que fogem dos parâa metros estudados na presente pesquisa. 


\section{Literatura Citada}

AGARWAL, S.K.D. e R.C. JOHARY, 1974. Some observations on the variation in the aminoacids in juices during clarification. Sharkara. Kanpur, 13:89-95. Apud. La sucrerie belge and sugar industry abstracts. England, 39(2):17, 1977 .

ALTERTHUM, F.; M.R.M. CRUZ; M.L.R. VAIRO e D.M. GAMBASSI, 1984. Efeito dos microrganismos contaminantes da fermentação alcoólica nas microdestilarias. STAB. Piracicaba, 3: $42-49$.

AMORIM, H.V., 1977. Introdução à bioguỉmica da fermentação alcoólica. Araras, PLANALSUCAR, 91 p.

AMORIM, H.V.; A.J. OLIVEIRA e H. CAMPOS, 1981. Infecção, problema sério na produção de álcool. In: CONGRESSO NACIONAL DA SOCIEDADE DE TÉCNICOS AÇUCAREIROS DO BRASIL, 20. Rio de Janeiro. Anais p. 158-168. 
ARAOJO, N.Q., 197C. Problemas da fermentação alcoólica industrial. Brasil Açucareiro. Rio de Janeiro, $75(4): 60-87$; (5) : 43-60.

ATKIN, L.A.; P.P. GRAY; W. MOSES e M. FEINSTEIN, 1962. Growth and fermentation factors for different brewery yeasts. Wallerstein Laboratories Communications. New York, 25:122134 .

BAILEY, J.L., 1967. Techniques in protejn chemistry. Amsterdam, Elsevier, $406 \mathrm{p}$.

BEEVERS, L. e R.H. HAGEMAN, 1969. Nitrate reduction in higher plants. Annual Review of Plant Physiology. California, $20: 494-518$.

BENNETT, M.C., 1957a. The physical nature and behavior of cane sugar juice. The International Sugar Journal. London, 59:176-177; 208-212.

BENNETT, M.C., 1957b. Behavior of adsorbed protein in cane sugar juice. Journal of Colloid Science. New York, 12 : $434-451$

BENNETT, M.C., 1959. The factors affecting stability and floculation in cane juice. The International Sugar. Journal. Lonảon, 61:77-80, 109-111; 135-138. 
BENNEIT, M.C. e J.M. RAGNAUTH, 1960. The effects of calcium and phosphate in cane juice clarification. The International Sugar Journal. London, 62:13-16.

BEVAN, D. e J. BOND, 1971. Microrganisms in fields and mill a preliminary survey. In: CONFERENCE OF THE QUEENSLAND SOCIETY OF SUGAR TECHNOLOGIS'TS, 389, Brisbane. Proceedings p. $137-143$.

BINKLEY, W.W., 1959. The fate of the principal simple sugars of cane juice during molasses formation. The International Sugar Journal. London, 61:173-175.

BLISS, L.R. e P. MADON, 1946. Sugar and Alcohol Technigues. Rio de Janeiro, Batista. 163 p.

BOND, J.D., 1925. Defecation in cane sugar manufacture. The Internacional Sugar Journal. London, 27:311-317.

BORDEN, R.J., 1948. Ni.trogen effects upon the yield and composition of sugar cane. Hawaitan Planter's Record. Honolulu, 52: 1-51.

BROCK, T.D., 1967. Life at high temperatures. Science. Washington, 158:1012-1019.

BRYAN-JONES, G., 1975. Lactic acid bacteria in distillery fermentations. In: LONG ASHTON SYMPOSIUM, 49, 1973. Lactic Acid Bacteria in Beverages and Food: Proceedings, ed. by J.G. CARR; C.V. CUTTING e G.C. WHITING. New York. Academic Press, p. 165-175. 
BURKHOLDER, P.R.; I. MCVEIGH e D. MOYER, 1944. Studies on some growth Eactors of yeasts. Journal of Bacteriology. Baltimore, 48:385-391.

CFSAR, M.A.A.; M.R. MAZZARI e E.R. OLIVEIRA, 1972. O teor de fósforo no caldo de algumas variedades de cana-de-açücar. Brasil Açucareiro, Rio de Janeiro, 79:34-38.

CESAR, M.A.A.; E.R. OLIVEIRA e M.R. MAZZARI, 1974. Teor de fösforó de algumas variedades de cana-de-açūcar. II. Segundo Corte (soca). Brasil Açucareiro. Rio de Janeiro, 83: $21-25$.

CLARKE, M.A.; E.J. ROBERTS; M.A. GODSHALL; M.A. BRANNAN; F.G. CARPENTER e E.E. COl.t, 1980. Sucrose loss in the manufacture of cane sugar. Sugar $\geq$ Azucar. New york, 75: $64-68$.

COPERSUCAR, 1983. Controle microbiológico na fabricação de açücar e älcool. Boletim Tëcnico COPERSujCAR. Säo Paulo, $22: 2-17$.

DAS, U.K., 1936. Nitrogen nutrition of sugar cane. Plant Physiology. Lancaster, 11:251-317.

DAVIES, J.G., 1936. Recent improvments in simple clarification for raw sugar production. Trindad, B.W.I., Imperial College of Tropic Agriculture. In: HONIG, P., Ed. Princípios de Tec nologia Azucarera. Mëxico. Editorial Continental, v.l, p.438. 
DAVIES, J.G., 1969. Tecnologia del Processo de Clarificação. In: HONIG, P., Ed. Principios de Tecnologia Azucarera. México, Editorial Continental, v.l, p. 465-502.

DEBEN, J.G., 1976. The chemistry of calcium phosphate precipitation in cane juice clarification. The International Sugar Journal. London, (925):3-7, 35-39.

DEER, N., 1916. The clarification of cane juice in the manufacture of raw sugar. The International sugar Journal. London, 18:502-506, 558-563.

DELGADO, A.A.; L.J. FERREIRA e D. BARBIN, 1973a.Estudos sobre o comportamento do fósforo na clarificação do caldo de cana. I - o comportamento do caldo de três variedades de cana-de-açūcar na clarificação, em função do teor de fösfọ. ro. Brasil Açucarejro. Rio de Janeiro, 81:55-64.

DELGADO, A.A.; L.J. FERREIRA, e D. BARBIN, 1973b.Estudos sobre o comportamento do fösforo na clarificação do caldo de cana. II - o comportamento de três variedades de cana-de-açū car na clarificação do caldo, em função de teorias variáveis de fósforo. Brasil Açucareiro. Rio de Janeiro, 82:5575.

DOBRZYCKI, J., 1982. Effectiveness of juice purification. Gazeta Cukrownicza. Warizawa. 90:153-156. Apud. Tate e Lyle's sugar industry abstracts. England, 45(5):148, 1983. 
DOOR, J.V.N. e F.P. LASSETER, 1946. Solid/liquid separation.

In: Alexander, J., Ed. Colloid Chemistry Theorical and Applied. New York, Reinhold, p. 782-799.

FARNELL, R.G.W., 1924. The effect of cold and of hot liming on the removal of albumin from cane juices. The International Sugar Journal. London, 26:359-363.

FORT', C.A. e B.A. SMITH, 1954. Studies of the chemical composition of materials causing turbidity in clarified sugarcane juices. Sugar Journal. New Orleans, 17:18-21.

FORT, C.A. e N. MCKAIG Jr., 1939. Comparative chemical. composition of juices of differents varieties of Louisiana sugarcane. Washington, U.S. Department of Agriculture, 68p. (Technical Bulletin, 688).

FULMER, E.I.; V.E. NELSON e F.E. SHERWOOD, 1921. The nutritional requeriments of yeast. II. The effect of the composition of the medium on the growth of yeast. The Journal of the American Chemical Society. Easton, Pa., 43:191-199.

GEERLIGS, H.C.P., 1924. Cane Sugar and its Manufacture. 2a. ed. New York, Van Nostrand. 342p.

GLORIA, N.A. e A.A. RODELLA, i972. Métodos de anālise quantitativa inorgânica em caldo de cana-de-açücar; vinhaça e melaço. I. Determinação de cálcio, magnēsio, potássio, enxôfre e fósforo em um mesmo extrato. Anais da ESALQ. Piracicaba, 29:5-17. 
GOMES, F.P., 1982. Curso de Estatística Expeximental. 10? ed. Piracicaba, Nobel. 430p.

GOMORI, G., 1942. A modification of the colorimetric phosphorus determination for use with the photoeletric colorimeter. Journal of Laboratory and Clinical Medicine. St. Louis, $27: 955-960$

GOSWAMI, A.K. e J.S. WILLCOX, 1969. Effect of applying increasing level of nitrogen to rye-grass. I. Composition of various nitrogenous tractions and the aminoacids. Journal of the Science of Food and Aqriculture. London, 20:592-594.

GRUSZECKA, H., 1983. Determination of the contents of phosphorus compounds in sugar industry solutions. Gazeta cukrornicza. Warszawa. 91:86-87 Apud. Tate e Lyle's sugar industry abstracts, England. 45(6):196-197, 1983.

GUAZON, G.A., 1935. Clarification and the role of colloids. The International Sugar Journal. London, 37:32.

GUIMARÃES, E. e G.M.A. SILVA, 1976. Estudo de variedades de cana-de-açücar quanto ao teor de fösforo no cáldo - ensaio preliminar. In: SEMINÄRIO COPERSUCAR DA AGROINDUSTRIA AÇUCAREIRA, 4ํ, Ãguas de Lindóia. Anais. p. 41-43. 
GUPTA, A.P. e B. PRASAD, 1967. Factors affecting ash content in cane juice. I. Cane varieties. In: CONVENTION OF THE SUGAR TECHNOLOGISTS' ASSOCIATION OF INDIA, 359, Kanpur. Proceedings p.207-209.

GUPTA, A.P.; I.S. JUNEJA e S.P. SHUKLA, 1968. Deterioration of sugar cane after harvest. In: CONVENTION OF THE SUGAR TECHNOLOGISTS' ASSOCIATION OF INDIA, 369, Kanpur. Proceedings p. 5-13.

GUPTA, S.C.; N.A. RAMAIAH e M.B. KUMAR, 1965. Studies on the use of phosphate in the clarified juice. In: CONVENTION OF THE SUGAR TECHNOLOGISTS' ASSOCIATION OF INDIA, 339, Kanpur. Proceedings p. 205-215.

HARDY, F., 1927. The component of sugarcane juice. Tropical Agriculture. Trinidad, 4:38-40 (suppl. sept.).

HARRISON, J.S., 1971. Yeast production. In: HOCKENHULL, D.J.D., Ed. Progress in Industrial Microbiology. Iondon, Churchill Livinstone, v. 10, p.129-177.

HARRISON, J.S. e J.C.J. GRAHAM, 1970. Yeasts in distillery practice. In: ROSE, A.H. e J.S. HARRISON, Ed. The Yeasts. London, Academic Press, v. 3, p. 283-348.

HARTELIUS, V., 1938. Comparative studies on the value of amino acids as a source of nitrogen for yeast. Biochemische Zeitschrift. Berlin, 299:317-333. Apud. Chemical Abstracts. Eastion, $\mathrm{Pa} ., 33(9): 3414,1939$. 
HARTT, C.E., 1970. Effect of nitrogen deficiency upon translocation of ${ }^{14} \mathrm{C}$ in sugarcane. Plant Physiology. Lancaster, 46:419-422.

HIDI, P., 1969. Aspects of the colloid chemistry of cane juice clarification. In: CONGRESS OF THE INTERNATIONAL SOCIETY OF SUGAR CANE TECHNOLOGISTS',139, Taiwan, 1968. Proceedings. Amsterdam, Elsevier, p. 1736-1743.

HONIG, P., 1934. Distribution of non-sugars in the cane. The International Sugar Journal. London, 36:272-273.

HONIG:- P., 1950. Clay in the cane sugar industry. Chronica Naturae. Kolff, 106:101-104. Apud. Sugar industry abstracts. England. $12(9): 168,1950$.

HONIG, P., 1952. Phosphor-containing non-sugars in cane juices. American Chemical Society, 2] Meeting. Apud. Sugar industry abstracts. England, 14(5):66, 1952 .

HONIG, P., 1960. The presence of phosphates in cane juices. In: CONGRESS OF THE INTERNATIONAL SOCIETY OF SUGAR CANE TECHNOLOGISTS', 109, Hawaii, 1959. Proceedings. Amsterdam, Elsevier, p. 356-361.

HONIG, P., 1969. No-azucares inorganicos. In: HONIG, P., Ed. Principios de Tecnologia Azucarera. México, Editorial Continental, v. 1, 265-322. 
JANAKIRAMAIAH，K.; N. SATYANARAYAN E T.S.N. MURTY, 1967. The need of phosphates in the cane juice clarification. In: CONVENTION OF THE SUGAR TECHNOLOGISTS' ASSOCIATION OF INDIA, 359, Kanpur. Proceedings p. 207-209.

JONES, R.P.; N. PAMMENT e P.F. GREENFIELD, 1981. Alcohol fermentation by yeasts - the effect of environmental and other variables. Process Biochemistry. London, 16:42-49.

KING, R.H., 1931. Cane juice liming and clarification. Industrial and Engineering Chemistry. Easton, Pa. 23:954-965.

KLAN, K., 1965. Métodos industriais da cana-de-açúcar. Brasil Açucareiro. Rio de Janeiro, 65:51-54.

KOWKABANY, G.N.; W.W. BINKLEY E M.L. WOLFROM, 1953. Aminoacidas in cane juice and cane final molasses. Journal of Agricultural and Food Chemistry. Easton, Pa., 1:84-87.

KUBADINOW, N. e W. HAMPEL, 1975. Le comportement des acides aminés libres au cours de l'épuration des jus. La Sucrerie Belge. Tienen, 94:394-404.

LANE, J.H. e L. EYNON, 1934. Determination of reducing sugar by Fehlings' solution with methilene blue indicator. London, Norman Rodger, 8p. 
LAPIN, A.P.; K.P. ZAKHAROV e V.Z. SEMENENKO, 1978. Effect of lime treatment of juice before 2 nd carbonatation on results of diffusion juice purifictation. Sakharnaya Promyshlennost! Moscow, 2:27-34. Apud. La sucrerie belge and sugar industry abstracts. England. 40 (9):116, 1978 .

LEE, H.A., 1926. Report on sugar cane pathology. Proceedings Hawailan Sugar Planters Association. Honolulu, p. 248-254. Apud. Chemical Abstracts. Easton, Pa., 21 (20):3414-3415, 1927.

LEVANDOVSKII, L.V.; A.D. KAVALENKO; V.K. YANCHEVSKII; V.V. RUDAYA e V.V. CHEREDNICHENKO, 1981. Determination of minerail nutrition needs in accelerated fermentation of molasses wort. Fermentn. Spirt. Prom. USSR, 1:11-13 Apud. Chemical. Abstracts. Columbus, $94(19): 501,1981$.

LITVINENKO, L.A.; M.E. KINTANA e S.B. PETRIKEVICH, 1980. Effect of nitrogen input concentration on the growth of Candida utilis in continuous culture with pulsed carbon feed. Mikrobiologiya. U.S.S.R., 49:945-951 Apud. Chemical Abstracts. Columbus, $94(11): 561,1981$.

LOPES, J.J.C.; J.R.A. LEME; S.E. FERRARI; A.L. VICENTE e A. MENCK, 1984. Eficiência de fermentação alcoólica utilizando-se duas fontes de fósforo em escala industrial. In: CONGRESSO NACIONAL DA SOCIEDADE DE TECNICOS AÇUCAREIROS E ALCOOLEIROS DO BRASIL, 39, São Paulo. Anais. p.446-448. 
LUCREDI, H.A.; J. FINQUERUT e K.H. LEIMER, 1984. Verificação da esterilidade do sistema de tratamento térmico do caldo de cana-de-açūcar para a fermentação. Boletim Técnico COPERSUCAR. São Paulo, $27: 25-28$.

MCNEIL, K.E. e P.A. INKERMAN, 1977. Preliminary studies on the deterioration of long-standing-burnt cane. In: CONFERENCE OF THE QUEENSLAND SOCIETY OF SUGAR TECHNOLOGISTS', 449, Brisbane, Proceedings, p.19-27.

MAGALHÃES, M.M.A.; M.L.R. VAIRO e W. BORZANI, 1980. Influēncia da adição de fonte de nitrogênio ao mosto no teor de proteina da levedura residual de fermentação alcoölica de melaço de cana-de-açúcar. Revista Brasileira de Tecnolo gia. Rio de Janeiro, 11:13-21.

MARTIN, L.F., 1969. Lás substancias organicas complejas, noazucares, de alto peso molecular. In: HONIG, P., Ed. Principios de Tecnologia Azucarera. México, Editorial Continental, v. 1, p.173-187.

MASSART, L. e J. HORENS, 1952. L'assimilation d'azote aminé par les levures. Enzymologia Acta Biocatalytica. Netherlands, 15:359-361.

MEEKER, E.W. e E.C. WAGNER, 1933. Titration of ammonia in presence of boric acid. Industrial and Engineering Chemistry Analytical Edition, Easton Pa., 5: 396-398. 
MINAMI, P.S., 1975. Assimilação de fontes de C e N por Sporotrichum schenckii na fase leveduriforme. Revista de Microbiologia. São Paulo, 6:35-37.

MORRIS, E.O., 1958. Yeast growth. In: COOK, A.H., Ed. The Chemistry and Biology of Yeasts. New York, Academic Press, p. $251-321$.

NIELSEN, N., 19.35. Untersuchumgen uber den gehalt der bierwurze an durch hefe assimilierbarem stickstoff. Comptes Rendus des Travaux du Laboratoire Carlsberg. Série Physiologique. Copenhague, 21:113-138.

NIZOVKIN, V.K. e I.Z. EMEL'YANOVA, 1960. Ebullioscopic method of determining reducing sugars. The International Sugar Journal. London, 62:230.

OLBRICH, H.T., 1963. Molasses. In: HONIG, P., Ed. Principles. of Sugar Technology. Ansterdam, Elsevier, v. 3, p.5ll-696.

OVERBEEK, J.T.G., 1952. Rheology of lyophobic systems. In: KRUYT, H.R., Ed. Cooloid Science. Amsterdam, Elsevier, V.1, p. 342-368.

OVERBEEK, J.T.G., 1952. Stability of hidrophobic colloids and emulsions. In: KRUYT, H.R., Ed. Colloid Science. Amsterdam, Elsevier, v.l, p.302-34l.

PAINE, H.S. e J.C. KEANE, 1927. A study of cane juice defecation at various $\mathrm{pH}$ values. The International Sugar Journal. London, 29:315-321. 
PAINE, H.S.; J.C. KEANE e M.A. MCCALIP, 1928. Influence of phosphate and colloid contents of cane juice on defecation. Industrial and Engineering Chemistry. Easton, Pa. 20:262267.

PAVLAS, $\dot{P}:$ e O.M. HAUSLEROVA, 1956. Proteins of thick juice and the decomposition products of proteins arising from alkalines decomposition during defecation and saturation. Listy Cukrovarnické. Prague, 72:263-268 Apud. Sugar Industry abstracts, England, 19(2-3):23, 1957.

PAYNE, J.H., 1969. Reacciones fundamentales del proceso de clarification. In: HONIG, P., Ed. Principios de Tecnologia Azucarera. México, Editorial Continental, v.l, p.437464 .

'PEREZ, M.D. e M.C.R. GUTIERREZ, 1977. Eliminación de las substancias coloidales del jugo de cana. Centro Azucar. Cuba, $\underline{2}: 35-51$.

PEREZ, M.D.; M.Q. SUAREZ e G.D. FERNANDEZ, 1978. Dinamica de las substancias nitrogenadas en el proceso de fabricación de azucar de cana. Centro Azucar., Cuba, 3:57-62.

PIRSCHALE, K., 1930. Biological observations on the growth of yeast with special reference to nitrates as a nitrogen source. Biochemische Zeitschrift. Berlin, 218:412-444. Apud. Chemical Abstracts. Easton, Pa. 24 (12):3034, 1930. 
RAMCHANDER, G. e T.S. RAO, 1957. Non-sugars in cane juice. In: CONYENTION OF THE SUGAR TECHNOLOGISTS' ASSOCIATION OF INDIA, 258, Kanpur. Proceedings p. 167-173.

REED, G. e H.J. PEPPLER, 1973. Yeast Technology. Westport, Connecticut, The Avi. 378p.

REINEFELD, E.; M. BLIESENER e J. SCHULZE, 1982. Contribution to the knowledge of behaviour of aminoacids during sugar recovery. 2. Investigations on the effect of process parameters of juice purification. Zuckerindustrie. Magdeburg, 107:1111-1119. Apud. Tate e Lyle's sugar industry abstracts. England, 45(2):41, 1983.

REVA, L.P. e G.A. SIMAKHINA, 1978. Determination of optimal juice alkalinity for predefecation. Sakharnaya Promyshlennost' Moscow, 3:36-40. Apud. La sucrerie belge and sugar industry abstracts. England, $40(7-8): 95,1978$.

REVA, L.P.; G.A. SIMAKHINA e V.M. LOGUIN, 1979. Effect of calcium ions on renaturation of protein precipitate. Sakharnaya Promyshlennost' Moscow, 11:20-22, Apud. La

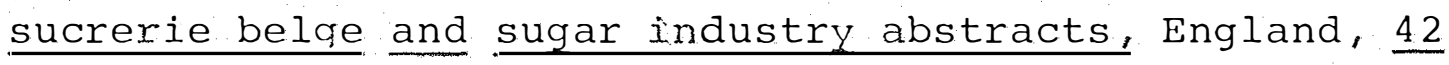
$(4): 52,1980$.

REVA, L.P.; G.A. SIMAKHINA e V.M. LOGUIN, 1983. Denaturation transformations of proteins during diffusion juice purification with lime. Sakharnaya Promyshlennost'. Moscow, 5: 40-43. i.pud. Tate e Lyle's sugar industry abstracts. England, $45(6): 183,1983$. 
ROBERTS, E.J. e L.F. MARTIN, 1961. Progress in determining organic non-sugars cane juice that affect sugar refining. Proceedings of the Technical Session on Bone Char, 69, 1959. Charlestown, p. 67-88. Apud. Sugar industry abstracts. England, 23(11):219, 1961 . ROBERTS, J.D. e M.C. CASERIO, 1965. Basic Principles of Organic Chemistry. New York, W.A. Benjamin, 1315p.

RODINI, M.A.T., 1985. Isolamento, caracterização e identificação de bactérias contaminantes de dornas de fermentação nas destilarias de etanol. Piracicaba, ESALQ/USP, 92 p. (Tese de Mestrado).

RODRIGUEZ, L.R.O.; J.A.V..HERRARA e E. R. SUAREZ, 1979. Process for inhibiting the deterioration of cane sugar. Us 4255204 , A 24 Jan. 79, no 6120. P 10 Mar. 81, 4p. Apud. Tate e Lyle's sugar industry abstracts. England, 43(4):115, 1981.

SAIGAL, D. e L. VISWANATHAN, 1980. Effect of clarification of molasses on alcoholic fermentation. In: CONVENTION OF THE SUGAR TECHNOLOGIS'TS' ASSOCIATION OF INDIA, 44\%, Kanpur. Proceedings p. 45G-52G.

SALINAS, J.G., 1946. Influencia del sistema de cultivo de la cana en la clarificabilidad de los guarapos. Memoria de la Asociacioon de Técnicos Azucareros de Cuba. Habana, 20:269272 .

SANHUEZA, R.H.V., 1979. Relações entre Xanthomonas albilineans,

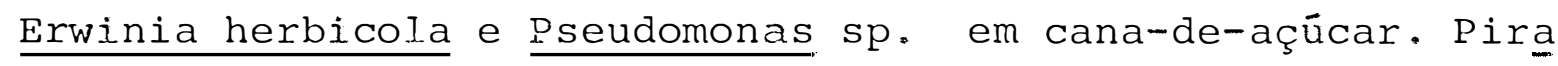
cicaba, ESALQ/USP, 77p. (Tese de Mestrado). 
SATYNARAYANA, K.V.S., 1952. Clarification of sugarcane juice with particular reference to the elimination of harmful nitrogen. In: CONVENTION OF THE SUGAR TECHNOLOGISTS' ASSOCIATION OF INDIA, 210, Kanpur. Proceedings p. 27-30.

SCHULTZ, A.S. e S. POMPER, 1948. Amino acids as nitrogen source for the growth of yeasts. Archives of Biochemistry. New York, 19: $184-192$.

SCHULTZ, A.S.; O.K. MEMANUS e S. POMPER, 1949. Amino acids as carbon source for the growth of yeasts. Archives of Biochemistry. New York, 22: $412-419$.

SCOTT, W., 1927. Summary of results at the factory of Imperial College of Tropical Agriculture, Crop 1927. The International Sugar Journal. London, 29:577-580.

SEIP, J.J., 1928. Colloids and their relation to clarification. Sugar News. Manila, 9:81-86.

SERRA, G.E.; J.P. STUPIELLO e M.A.A. CESAR, 1974. Formas de ocorrência do fôsforo no caldo de cana-de-açúcar. JORNADA CIENTífICA DA FACULDADE DE CIÊNCIAS MÉDICAS E BIOLOGICAS DE BOTUCATU, $\underline{4 .}$, Anais. Botucatu, S.P. p.42.

SHARMA, S.C. e N.S. GUPTA, 1970. A study of the chemical composition of cane juice of B.O. 14 variety with age. In: CONVENTION OF THE SUGAR TECHNOLOGISTS' ASSOCIATICN OF INDIA, 379, Kanpur. Proceedings p.63-79.

SHARMA, S.C. e P.C. JOHARY, 1984. Aminoacid removal during cane juice clarification. The International Sugar Journal. London, 86: 7-11. 
SHARMA, S.C.; P.C. JOHARY e G.S.C. RAO, 1981. Cane juice phosphates and clarification. The International Sugar Journal. London, 83:3-5.

SHUKLA, J.P. e K.A. PRABHU, 1961. Eletrophoretic studies of proteins in cane juice. Sharkara, Kanpur, 4:112-119. Apud.

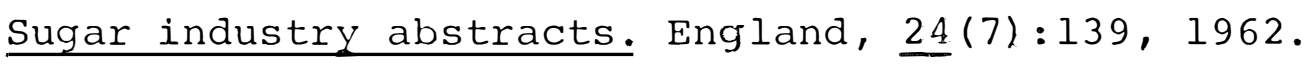

SILVA, H., 1983. Efeitos da adubação do sorgo sacarino (Sorghum bicolor (t.) MOENCH) na qualidade de caldo para multiplicação de leveduras e fermentação alcoólica. Piracicaba, ESALQ/USP, 295p. (Tese de Doutoramento).

SILVA Jr., J.F., 1976. Efeito da aplicação de fontes de fosfato na clarificação do caldo de cana. In: SEMINÂRIO COPER-

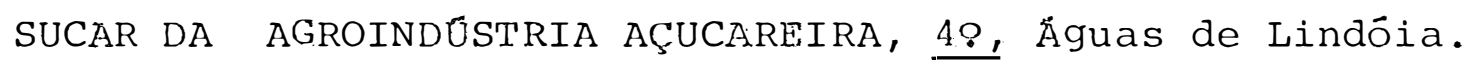
Anais. p. 339-353.

SILVA, M.H., 1974. Control de inversión en el jugo del molino. Sugar y Azucar. New York, 69:41-43.

SKOLA, V., 1923. Liming raw beet juice and separating the precipitate produced previous to carbonating. The International Sugar Journal. London, 25:496.

SMYTHE, C.V., 19.39. The effect of certain tissue extracts of ammonia salts and of certain amides on the rate of fermentation by bakers' yeast. Enzymologia. Holland, $6: 9-14$. 
SPENCER, G.L. e G.P. MEADE, 1945. Cane Sugar Handbook. 8?. ed. New York, John Wiley. $834 \mathrm{p}$.

STANEK, V., 1921. A precipitation of amino acids into the sludge during the saturation of the lime with carbon and sulphur dioxides. Listy Cukrovarnické. Prague, 39:257-259, 269-270. Apud. Chemical Abstracts. Easton, Pa., 15(16): 2745,1921 .

STEVENS, R., 1955. A nitrogen balance carried out in a commercial sugar factory. In: MEETING OF BRITISH WEST INDIES SUGAR TECHNOLOGISTS'. Barbados. Proceedings. p.86-91. STUDNICKY, J., 1978. Obtaining proteins from cane juice. ATAC. Cuba, 37:16-21.

STUPIELLO, J.P. e J. HORII, 1981. Condução da fermentação alcoólica. Saccharum. São Paulo, 17:43-46.

SULLIVAN, M., 1978. Some aspects of nitrogen in beet. La Sucrerie Belge. Tienen, 97:175-180.

SUOMALAINEN, H. e E. OURA, 1971. Yeast nutrition and solute uptake. In: ROSE, A.A. e J.S. HARRISON. Ed. The Yeasts. 3. ed. London, Academic Press, v. 2., p. 3-74.

SURDIN, Y.; W. SLY; J.SIRE; A.M. BORDES E H.R. SZULMAJSTER, 1965. Propriétés et contrôle génētiquie du système d'accumulation des acides aminés chez saccharomyces cerevisiae. Biochimica et Biophysica ACTA. Amsterdam, 107: 
TAO-TZE, Y.; H. KUO-MING e Y. WANG-HWA, 1983. The preliminary study of free amino acids in green tops of sugarcane. In: CONGRESS OF THE INTERNATIONAL SOCIETY OF SUGAR CANE TECHNOLOGISTS', 180, Cuba. Proceedings. v. 4, p.356-361.

THORNE, R.S.W., 1949. Nitrogen metabolism of yeast.

A consideration of the mode of assimilation of amino acids. The Journal of the Institute of Brewing. London, 55:201-222.

THORNE, R.S.W., 1933. The ability of certain pure chemical compounds to formation as nitrogen source for yeast. The Journal of the Institute of Brewing. London, 39:608-621. TILBURY, R.H., 1968. Biodeterioration of harvested sugar cane. In: WALTER, A.H. e J.J. ELPICK, Ed. Biodeterioration of Materials. London, Elsevier, p. 717-730.

VAIRO, M.L.R.; R.E. GREGORI e W. BORZANI, 1975. Respostas de um cultivo de Saccharomyces cerevisiae a perturbações por impulso provocadas por adição de sulfato de amônio. Revista Brasileira de Tecnologia. São Paulo, $6: 1-6$.

VASATKO, J. e A. DANDAR, 1971. Effect of the sugar content of milk of lime on purification of beet juice. La Sucrerie Belge. Tienen, 90:485-489.

VEGA, J.R., 1957. La preclarification del guarapo. Memória de la Conferencia Anual de La Asociacion de Tecnicos Azucareros de Cuba. Habana, 31:53-68. 
VIGNES, E.C. e R. FROBERVILLE, 1960. Protei: extraction from sugar cane juice. Report Mauritus Sugar Industry Research Institute. Reduit, p. 93-97.

VILLELA, G.G.; M. BACILA e H. TASTALDI, 1973. Técnica e Experimentos de Bioguímica. Rio de Janeiro, Guanabara Koogan. $552 \mathrm{p}$.

WALKER, H., 1923. Phosphoric acid in cane juices. Industrial and Engineering Chemistry. Easton, Pa., 15:164-165.

WICKERHAM, L.J., 1946. A critical evaluation of the nitrogen assimilation tests commonly used in the classification of yeast. Journal of Bacteriology. Baltimore, 52:293-301.

WIGGINS, L.F., 1969. No-azucares nitrogenados (los aminoacidos e las proteinas). In: HONIG, P., Ed. Principios de Tecnologia Azucarera. México, Editorial Continental. v.l, p. $155-172$.

WIGGINS, L.F. e J.H. WILLIAMS, 1951. Constituents of cane juice. 2. Quantitative examination of the aminoacids of cane juice. In: MEETING OF BRITISH WEST INDIES SUGAR TECHNOLOGISTS', Barbados. Proceedings p. 40-49.

WIGGINS, L.F. e J.H. WILLIAMS, 1955. Amino acid content of West Indies sugar cane. Journal of Agricultural and Food Chemistry. Easton, Pa., 3:34l-345.

WILLIAMS, R.J.; R.E. EAKIN e E.E. SNELL, 1940. The relationship of inositol, thiamin, biotin, pantothenic acid and vitamin $B_{6}$ to the growth of yeasts. The Journal of the American Chemical Society. Easton, Pa., 62:1204-1205. 
WILSON, S.J., 1956. The aminoacids in final molasses and cane juice. In: CONFERENCE OF THE QUEENSLAND SOCIETY OF SUGAR TECHNOLOGISTS', 239, Brisbane, proceedings p.65-69.

YADAV, B.C.; D.S. DAHIYA e P. TAURO, 1982. Studies on fermentation of sugar cane juice for the production of ethanol. In: CONVENTION OF THE SUGAR TECHNOLOGISTS' ASSOCIATION OF INDIA, 469, Kanpur. Proceedings, p.G41-G52.

YAROVENKO, V.L., 1964. Principles of the continuous alcohol and butanol-acetone fermentation process. In: INTERNATIONAL ,SYMPOSIUM ON CONTINUOUS CULTIVATION OF MICROORGANISMS, 29, Prague, 1962. Proceedings, ed. bY I. MALLEK, K. BERAN e J. HOSPODKA. New York, Academic Press, p.205-219.

ZAGO, E.A., 1982. Efeito da concentração de N, P, Mg, Mn e Zn na multiplicação de leveduras industriais. Piracicaba, ESALQ/USP, 125p. (Tese de Doutoramento).

ZAKHAROV, K.P.; R.G. ZHIZHINA e V.Z. SEMENENKO, 1983. Influence of main defecation on content of nitrogen compounds in thick juice. Sakharnaya Promyshlennost'. Moscow, 10:22-24. Apud.

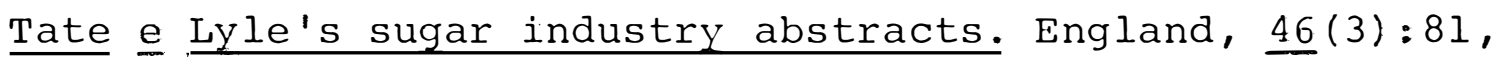
1984.

ZHURA, K.D. e L.V. ZAGAIKEVICH, 1967. Some reasons for decrease of juice pH during evaporation. Sakharnaya Promyshlennost' Moscow, 41:36-37. Apud. Sugar industry abstracts, England, $\underline{30}(6): 90,1968$. 
$A P \hat{E} N D I C E$ 
Quadro 17 - Efeito do tratamento térmico do caldo na população microbiana - Amostra 1

\begin{tabular}{lcccccc}
\hline Causa da variaçäo & G.I. & S.Q. & Q.M. & E & Nivel \\
\hline Blocos & 2 & 0,009059 & 0,004529 & $1,00 \mathrm{~ns}$ & 44,51 \\
Tratamentos & 2 & 2,050380 & 1,025190 & $225,85 * *$ & 0,01 \\
Residuo & 4 & 0,018157 & 0,004539 & & \\
\hline Total & 8 & 2,077600 & & & \\
\hline
\end{tabular}

Dados transformados para $\sqrt{\mathrm{x}+0,5}$

** - Ao nível de 1\% ao menos um contraste de médias difere de zero

Coeficiente de variaçäo $=6,44879 \%$

Teste Tukey $5 \%$ para tratamentos

DMS $=0,196048$

Tratamento $1=1,71977 \mathrm{~A}$

Tratamento $2=0,70725 \mathrm{~B}$

Tratamento $3=0,70725 \mathrm{~B}$

Quadro 18 - Efeito do tratamento téxmico do caldo na populaçăo miccobiana Amostra 2

\begin{tabular}{lrrrrr}
\hline Causa da variação & G.L. & S.Q. & Q.M. & F & Nível \\
\hline Blocos & 2 & 0,017902 & 0,008951 & 1,02 ns & 43,81 \\
Tratamentos & 2 & 31,370700 & 15,685300 & $1790,28 * *$ & 0,00 \\
Resĩuo & 4 & 0,035046 & 0,008761 & & \\
\hline Total & 8 & 31,423600 & & & \\
\hline
\end{tabular}

Dados transformados para $\sqrt{x+0,5}$

** - Ao nível de 1\% ao menos un contraste de mëdias difere de zero

Coeficiente de variação $=4,61002 \%$

Teste Tukey 5: para tratamentos

DMS $=0,272369$

Tratamento $I=4,67073$

Tratamento $2=0,7] .157 \mathrm{~B}$

Tratamento $3=0,70894 \mathrm{~B}$ 
Quadro 19 - Efeito do tratamento téxmico do caldo na população microbiana - Amostra 3

\begin{tabular}{lcrrrr}
\hline Causa da variaçắ & G.L. & S.Q. & Q.M. & F & Nivel \\
\hline Blocos & 2 & 0,020695 & 0,010347 & 0,99 ns & 44,81 \\
Tratamentos & 2 & 24,938300 & $12,4691.00$ & $11.90,24^{* *}$ & 0,00 \\
Resíduo & 4 & 0,041904 & 0,010476 & & \\
\hline Total & 8 & 25,000900 & & & \\
\hline
\end{tabular}

Dados transformados para $\sqrt{x+0,5}$

** - Ao nível de $1 \%$ ao menos um contraste de mëdias difere de zero Coeficiente de variação $=5,42678 \%$

Teste Tukey 5: para tratamentos

DMS $=0,297831$

Tratamento $I=4,24018 \mathrm{~A}$

Tratamento $3=0,70958 \mathrm{~B}$

Tratamento $2=0,70845 \mathrm{~B}$

Quadro 20 - Efeito do tratamento témico do caldo na população microbiana - Amostra 4

\begin{tabular}{lcrrrr}
\hline Causa da variaçäo & G.L. & S.Q. & Q.M. & F & Nivel \\
\hline Blocos & 2 & 0,018547 & 0,009274 & 0,99 ns & 44,60 \\
Tratamentos & 2 & 141,394000 & 70,696800 & $584,51 * *$ & 0,00 \\
Resỉduo & 4 & 0,037285 & 0,009321 & & \\
\hline Total & 8 & 141,449000 & & & \\
\hline
\end{tabular}

Dados transformados para $\sqrt{x+0,5}$

** - Ao nível de $1 \%$ ao menos um contraste de médias difere de zero

Coeficiente de variação $=2,74816 \%$

Teste de Tukey 5\% para tratamentos

DMS $=0,280935$

Tratamento $I=9,11856 \mathrm{~A}$

Tratamento $2=0,71349 \mathrm{~B}$

Tratamento $3=0,70734 \mathrm{~B}$ 
Quadro 21 - Efeito do tratamento térmico do caldo na população microbiana - Amostra 5

\begin{tabular}{lcrrrr}
\hline Causa da variação & G.L. & S.Q. & Q.M. & F & Níel \\
\hline Blocos & 2 & 0,014465 & 0,007233 & 1,28 ns & 37,08 \\
Tratamentos & 2 & 707,279000 & 353,639000 & $62807,90 * *$ & 0,0 \\
Residuo & 4 & 0,022522 & 0,005630 & & \\
\hline Total & 8 & 707,316000 & & & \\
\hline
\end{tabular}

Dados transformados para $\sqrt{x+0,5}$

** - Ao nủvel de 1 응 ao menos um contraste de médias difere de zero

coeficiente de variação $=1,04965 \%$

Teste Tukey 5\% para tratamentos.

$\mathrm{DMS}=0,218345$

Tratamento $\mathrm{l}=19,68470 \mathrm{~A}$

Tratamento $2=1,00668 \mathrm{~B}$

Tratamento $3=0,75470^{\circ} \mathrm{C}$

Quadro 22 - Efeito do tratamento ténnico do caldo na população microbiana - Amostra 6

\begin{tabular}{lcrrrr}
\hline Causa da variaçäo & G.L. & S.Q. & Q.M. & F & Nível \\
\hline Blocos & 2 & 0,758057 & 0,379028 & $0,92 \mathrm{~ns}$ & 46,85 \\
Tratamentos & 2 & 991,933000 & 495,967000 & 1206,61 & 0,00 \\
Residuo & 4 & 1,644170 & 0,411041 & & \\
\hline Total & 8 & 994,335000 & & & \\
\hline
\end{tabular}

Dados transformados para $\sqrt{\mathrm{x}+0,5}$

** - Ao núvel de 1응 ao menos um contraste de médias difere de zero

Coeficiente de variação $=7,77955 \%$

Teste Tukey 5\% para tratamentos

$\mathrm{DMS}=1,86557$

Tratamento $1=23,08750 \mathrm{~A}$

Tratamento $2=0,925.10 \mathrm{~B}$

Tratamento $3=0,71087 \mathrm{~B}$ 
Quadro 23 - Efeito do tratamento térmico do caldo na população microbiana - Amostra 7

\begin{tabular}{lcrrrrr}
\hline Causa da variação & G.T. & S.Q. & Q.M. & F & Nível \\
\hline Blocos & 2 & 0,079826 & 0,039913 & $1,00 \mathrm{~ns}$ & 44,34 \\
Tratamentos & 2 & 9,573900 & 4,786950 & $120,35 * *$ & 0,03 \\
Resíduo & 4 & 0,159100 & 0,039775 & & \\
\hline Total & 8 & 9,812820 & & & \\
\hline
\end{tabular}

Dados transfomados para $\sqrt{x+0,5}$

** - Ao nîvel de 10 ao menos um constraste de mëdias difere de zero

Coeficiente de variação $=13,8191$ ?

Teste de Tukey 5\% para tratamentos

Di4S: $=0,580329$

Tratamento $1=2,90179 \mathrm{~A}$

Tratamento $2=0,72035 \mathrm{~B}$

Tratamento $3=0,70746 \mathrm{~B}$

Quadro 24 - Efeito da defecação do caldo na população microbiana Amostra 1

\begin{tabular}{lrrrrr}
\hline Causa da variação & G.L. & S.Q. & Q.M. & F & Nível \\
\hline Blocos & 2 & 0,054024 & 0,027012 & 1,00 ns & 44,45 \\
Tratamentos & 2 & 94,442800 & 47,221400 & $1747,56 * *$ & 0,00 \\
Residuo & 4 & 0,108086 & 0,027021 & & \\
\hline Total & 8 & 94,604900 & & & \\
\hline
\end{tabular}

Dados transformados para $\sqrt{\mathrm{x}+0,5}$

** - Ao nivel de 1o ao menos um contraste de médias difere de zero

coeficiente de variação $=5,48283$ 응

Teste Tukey 5\% para tratatamentos

DNS $=0,478326$

Tratamento $I=7,57931 \mathrm{~A}$

Tratamento $3=0,70760 \mathrm{~B}$

Tratamento $2=0,70746 \mathrm{~B}$ 
Quadro 25 - Efeito da defecação do caldo na população microbiana Amostra 2

\begin{tabular}{lcrrrr}
\hline Causa da variação & G.L. & S.Q. & Q.M. & F & Nível \\
\hline Blocos & 2 & 1,823360 & 0,911682 & $0,82 \mathrm{~ns}$ & 50,28 \\
Tratamentos & 2 & 302,485000 & 151,243000 & $136,13^{* *}$ & 0,02 \\
Resíduo & 4 & 4,444030 & 1,111010 & & \\
\hline Total & 8 & 308,753000 & & & \\
\hline
\end{tabular}

Dados transformados para $\sqrt{\mathrm{x}+0,5}$

** - Ao nivel de $1 \%$ ao menos um contraste de mëdias difere de zero

Coeficiente de variação $=12,4244$ 응

Teste Tukey 5\% para tratamentos

$\mathrm{DMS}=3,0671$

Tratamento $1=16,13800 \mathrm{~A}$

Tratamento $2=7,20040 \mathrm{~B}$

Tratamento $3=2,11245 \mathrm{C}$

Quadro 26 - Efeito da defecação do caldo na população microbiana Amostra 3

\begin{tabular}{lrrrrr}
\hline Causa da variação & G.L. & S.Q. & Q.M. & F & Nivel \\
\hline Blocos & 2 & 0,016632 & 0,008316 & $0,90 \mathrm{~ns}$ & 47,66 \\
Tratamentos & 2 & 424,448000 & $212,22400022894,30 * *$ & 0,00 \\
Resíduo & 4 & 0,037079 & 0,009270 & & \\
\hline Total & 8 & 424,502000 & & & \\
\hline
\end{tabular}

Dados transfomados para $\sqrt{x+0,5}$

** - Ao nivel de 1\% ao menos un contraste de médias difere de zero

Coeficiente de variação $=1,71228 \%$

Teste Tukey 5\% para tratamentos

DMS $=0,280158$

Tratamento $1=15,33460 \mathrm{~A}$

Tratamento $2=0,82663 \mathrm{~B}$

Tratamento $3=0,70741 \mathrm{~B}$ 
Quadro 27 - Efeito da defecação do caldo na população microbiana Amostra 4

\begin{tabular}{lrrrrr}
\hline Causa da variaçäo & G.L. & S.Q. & Q.M. & F & Nível \\
\hline Blocos & 2 & 0,029419 & 0,014709 & 0,99 ns & 44,87 \\
Tratamentos & 2 & 914,600000 & 457,300000 & $30643,80^{* *}$ & 0,00 \\
Resỉduo & 4 & 0,059692 & 0,014923 & & \\
\hline Total & 8 & 914,689000 & & & \\
\hline
\end{tabular}

Dados transformados para $\sqrt{x+0,5}$

** - Ao nỉvel de 1\% ao menos um contraste de mëdias difere de zero

Coeficiente de variação $=1,55867$ 음

Teste Tukey 5\% para tratamentos

DMS $=0,355467$

Tratamento $\mathrm{I}=22,09380 \mathrm{~A}$

Tratamento $2=0,71027 \mathrm{~B}$

Tratamento $3=0,70824 \mathrm{~B}$

Quadro 28 - Efeito da defecação do calddo na população microbiana Amostra 5

\begin{tabular}{lcrrrrr}
\hline Causa da variação & G.L. & S.Q. & Q.M. & F & Nîvel \\
\hline Blocos & 2 & 0,231689 & 0,115845 & 1,00 ns & 44,44 \\
Tratamentos & 2 & 73,635300 & 36,817700 & $317,89^{* *}$ & 0,00 \\
Resíduo & 4 & 0,463272 & 0,115818 & & \\
\hline Total & 8 & 74,330300 & & & \\
\hline
\end{tabular}

Dados transformados para $\sqrt{x+0,5}$

** - Ao nivel de 2 \% ao menos um contraste de mëdias difere de zero Coeficiente de variação $=12,4551 \%$

Teste Tukey 5\% para tratamentos

DMS $=0,99028$

Tratamento $1=6,77754 \mathrm{~A}$

Tratamento $2=0,71227 \mathrm{~B}$

Tratamento $3=0,70729 \mathrm{~B}$ 
Quadro 29 - Efeito da defecaçäo do caldo na popularão microhiana Amostra 6

\begin{tabular}{lcrrrr}
\hline Causa da variaçäo & G.L. & S.Q. & Q.M. & F & Nũvel \\
\hline Blocos & 2 & 1,962710 & 0,981354 & 1,00 ns & 44,44 \\
Tratamentos & 2 & 752,397000 & 376,199000 & $383,41 * *$ & 0,00 \\
Resỉduo & 4 & 3,924740 & 0,981186 & & \\
\hline Total & 8 & 758,235000 & & & \\
\hline
\end{tabular}

Dados transfomados para $\sqrt{x+0,5}$

** - Ao nível de 18 ao menos um contraste de médias difere de zero Coeficiente de variação $=13,7435 \%$

Teste Tukey 5\% para tratamentos

$\mathrm{DMS}=2,88234$

Tratamento $I=20,13800 \mathrm{~A}$

Tratamento $3=0,75674 \mathrm{~B}$

Tratamento $2=0,72757 \mathrm{~B}$

Quadro 30 - Efeito da defecação do caldo na população microbiana Amostra 7

\begin{tabular}{lrrrrr}
\hline Causa da variação & G.L. & S.Q. & Q.M. & F & Nîvel \\
\hline Blocos & 2 & 0,666687 & 0,333344 & 1,00 ns & 44,44 \\
Tratamentos & 2 & 1007,190000 & 503,594000 & $1511,03 * * 0,00$ \\
Residuo & 4 & 1,333070 & 0,333267 & \\
\hline Total & 8 & 1009,190000 & & & \\
\hline
\end{tabular}

Dados transfomados para $\sqrt{\mathrm{x}+0,5}$

** - Ao nivel de 1\% ao menos um contraste de médias difere de zero

Coeficiente de variação $=7,05092 \%$

Teste Tukey 5\% para tratamentos

DMS $=1,67983$

Tratamento $I=23,14810 \mathrm{~A}$

Tratamento $3=0,70718 \mathrm{~B}$

Tratamento $2=0,70718 \mathrm{~B}$ 
Quadro 31 - Efeito da defecação do caldo na população microbiana Amostra 8

\begin{tabular}{lcrrrr}
\hline Causa da variaçäo & G.I. & S.Q. & Q.M. & F & Nivel \\
\hline Blocos & 2 & 0,012604 & 0,006302 & $1,07 n s$ & 42,40 \\
Tratamentos & 2 & 599,281000 & 349,640000 & $59439,80 * *$ & 0,00 \\
Resíduo & 4 & 0,023529 & 0,005882 & & \\
\hline Total & 8 & 699,317000 & & & \\
\hline Dados transfomados para $\sqrt{\mathrm{x}}+0,5$ & & & & \\
\hline
\end{tabular}

** - Ao nivel de $1 \%$ ao menos um contraste de médias difere de zero

Coeficiente de variação $=1,06189 \%$

Teste Tukey 50 para tratamentos

DMS $=0,223173$

Tratamento $\mathrm{I}=19,68470 \mathrm{~A}$

Tratamento $2=1,25340 \mathrm{~B}$

Tratamento $3=0,72970 \mathrm{C}$

Quadro 32 - Efeito da cefecação do caldo na população microbiana Amostra 9

\begin{tabular}{lcrrrr}
\hline Causa da variação & G.L. & S.Q. & Q.M. & F & NÍvel \\
\hline Blocos & 2 & 0,799744 & 0,399872 & 1,00 ns & 44,47 \\
Tratatamentos & 2 & 1000,610000 & 500,304000 & $1250,06 * *$ & 0,0 \\
Residuo & 4 & 1,600890 & 0,400223 & & \\
\hline
\end{tabular}

Total 81003,010000

Dados transformados para $\sqrt{x+0,5}$

** - Ao nivel de 18 ao menos un contraste de mëdias difere de zero

coeficiente de variaçäo $=7,73779 \%$

Teste Tukey 5\% para tratamentos

$D M S=1,84086$

Tratamento $I=23,08750 \mathrm{~A}$

Tratamento $3=0,72970 \mathrm{~B}$

Tratamento $2=0,71040 \mathrm{~B}$ 
Quadro 33 - Efeito da defecação do caldo na população microbiana Amostra 10

\begin{tabular}{lcccccc}
\hline Causa da vaxiaçáo & G.t. & S.Q. & Q.M. & F & Nivel. \\
\hline Blocos & 2 & 0,079636 & 0,039818 & 1,00 ns & 44,45 \\
Tratamentos & 2 & 9,604860 & 4,802430 & $120,60 * *$ & 0,03 \\
Residuo & 4 & 0,159288 & 0,039822 & & \\
\hline Total & 8 & 9,843780 & & & & \\
\hline
\end{tabular}

Dados transformados para $\sqrt{\mathrm{x}+0,5}$

** - Ao nivel de 18 ao menos um contraste de mëdias difere de zero

Coeficiente da variação $=13,85 \%$

Teste Tukey 5\% para tratamentos

$\mathrm{DMS}=0,580674$

Tratamento $1=2,90179 \mathrm{~A}$

Tratamento $2=0,71344 \mathrm{~B}$

Tratamento $3=0,70725 \mathrm{~B}$ 